NARA CAROLINA MERLOTTO

\title{
A ATUAÇÃO DO TRIBUNAL DE CONTAS DA UNIÃO SOBRE AS AGÊNCIAS REGULADORAS: \\ entre a independência e o controle
}

Dissertação de Mestrado

Orientador: Professor Titular Dr. Floriano de Azevedo Marques Neto

UNIVERSIDADE DE SÃO PAULO

FACULDADE DE DIREITO

São Paulo - SP

2018 



\title{
A ATUAÇÃO DO TRIBUNAL DE CONTAS DA UNIÃO SOBRE AS AGÊNCIAS REGULADORAS: \\ entre a independência e o controle
}

\begin{abstract}
Dissertação apresentada à Banca Examinadora do Programa de Pós-Graduação em Direito da Faculdade de Direito da Universidade de São Paulo como exigência parcial para obtenção do título de Mestra em Direito, na área de concentração Direito do Estado, sob a orientação do Prof. Titular Dr. Floriano de Azevedo Marques Neto.
\end{abstract}

UNIVERSIDADE DE SÃO PAULO

FACULDADE DE DIREITO

São Paulo - SP 


\section{Catalogação da Publicação \\ Serviço de Biblioteca e Documentação \\ Faculdade de Direito da Universidade de São Paulo}

Merlotto, Nara Carolina

A atuação do Tribunal de Contas da União sobre as agências reguladoras: entre a independência e o controle / Nara Carolina Merlotto; orientador Floriano de Azevedo Marques Neto - São Paulo, 2018.

p.

Dissertação (Mestrado - Programa de Pós-Graduação em Direito Comercial) - Faculdade de Direito, Universidade de São Paulo, 2018.

1. A atuação do Tribunal de Contas da União sobre as agências reguladoras. 2. Regulação.

3. Controle. I. Marques Neto, Floriano Peixoto de Azevedo. II. Título. 
Nome: Nara Carolina Merlotto

Título: A atuação do Tribunal de Contas da União sobre as agências reguladoras: entre a independência e o controle

Dissertação apresentada à Banca Examinadora do Programa de Pós-Graduação em Direito da Faculdade de Direito da Universidade de São Paulo como exigência parcial para obtenção do título de Mestra em Direito, na área de concentração Direito do Estado, sob a orientação do Prof. Titular Dr. Floriano de Azevedo Marques Neto.

Aprovada em: ...................

\section{Banca examinadora}

Prof. Titular Dr. Floriano de Azevedo Marques Neto (Orientador) - Instituição: FDUSP Banca realizada em:

Resultado:

Banca Examinadora

Prof:: Instituição:

Julgamento: Assinatura:

Prof:: Instituição:

Julgamento: Assinatura:

Prof.: Instituição:

Julgamento: Assinatura: 



\section{AGRADECIMENTOS}

Seria impossível iniciar este trabalho sem agradecer, antes de tudo e todos, aos meus pais: LÚCIA DE FÁTIMA RIBEIRO STUQI MERLOTTO e JOSÉ CARLOS MERLOTTO. Sem eles, jamais teria tido todas as oportunidades que me fizeram chegar a este momento. O apoio sempre incondicional foi essencial para que fossem superados todos os obstáculos que surgiram no decorrer deste extenso caminho. Mérito depende muitas vezes de oportunidades, e são eles os primeiros e principais responsáveis por todas as oportunidades que tive.

Devo agradecer ainda ao meu orientador, FLORIANO DE AZEVEDO MARQUES NETO, não apenas por ter me recebido como seu orientando e acreditado no meu projeto, mas por todas as conversas e ensinamentos ao longo desses três anos. Seu conhecimento e suas contribuições foram, sem qualquer dúvida, essenciais para que este projeto fosse possível.

Finalmente, agradeço a todos aqueles que, de qualquer forma, estiveram presentes na minha vida nesses três últimos anos. A elaboração de uma dissertação de mestrado faz com que muitas vezes tenhamos que abrir mão da convivência frequente para que possamos dedicar nossas horas à árdua tarefa de ler, escrever e pensar. Para aqueles que não estão inseridos no processo pode ser muitas vezes difícil de compreender essas renúncias. Ainda assim, tenho a sorte de ter ao meu lado pessoas que não apenas compreendem, mas apoiam incondicionalmente este trabalho. A todas essas pessoas, meu muito obrigada! 



\section{RESUMO}

MERLOTTO, Nara Carolina. A atuação do Tribunal de Contas da União sobre as agências reguladoras: entre a independência e o controle. 2018. 266 p. Dissertação (Mestrado em Direito) - Faculdade de Direito, Universidade de São Paulo, São Paulo, 2018 .

Desde a instituição das principais agências reguladoras no Brasil, a partir da segunda metade dos anos 1990, tem-se destacado a relevância dos mecanismos de garantia da sua independência (autonomia) para o adequado desempenho da regulação (função regulatória). Partindo-se da premissa de que somente a previsão abstrata de independência pelas normas instituidoras das agências reguladoras não é suficiente à garantia de suas funções institucionalmente concebidas, especialmente quando confrontadas com as competências e atuação das demais instituições, esta dissertação tem o objetivo de analisar como a interação entre o Tribunal de Contas da União (TCU) e as agências reguladoras federais impacta a regulação. Para tanto, são abordados os principais aspectos institucionais das entidades objeto do estudo (agências reguladoras e TCU) e as suas respectivas funções. Em seguida, a partir de análise da jurisprudência do TCU, busca-se apresentar a maneira pela qual se efetiva o controle que a Corte de Contas exerce sobre as agências reguladoras. A análise dessa interação possibilita testar a hipótese de que, no exercício do controle externo sobre as agências reguladoras, o TCU assume o papel de um agente ativo na regulação, comprometendo a autonomia arquitetada para agências para o desempenho da regulação.

Palavras-chave: Agências Reguladoras. Tribunal de Contas da União. Controle. Regulação.

A atuação do Tribunal de Contas da União sobre as agências reguladoras: entre a independência e o controle 



\begin{abstract}
MERLOTTO, Nara Carolina. The Supreme Audit Court's activities over the regulatory agencies: between independence and control. 2018. 266 p. Master - Faculty of Law, University of São Paulo, São Paulo, 2018.

Since the creation of the main regulatory agencies in Brazil, beginning in the second half of the 1990's, highlighted has been the relevance of the mechanisms that guarantee their independence (autonomy) in order to properly perform the regulation (regulatory purpose). Assuming that the abstract provision of independence (granted) by the rules that create the regulatory agencies alone is not sufficient to guarantee the functions institutionally conceived, especially when confronted with the competences and activities of the other institutions, this dissertation aims at analyzing how the interaction between the Supreme Audit Court (TCU) and the federal regulatory agencies impacts the regulation. In order to do so, discussion will focus on the main institutional aspects of the entities to be studied (regulatory agencies and TCU) and their respective functions. Subsequently, based on the analysis of TCU's precedents, presented will be how the TCU's control over the regulatory agencies transpires. The analysis of this interaction allows for the testing of the hypothesis that, during the exercising of its external control over the regulatory agencies, TCU takes on the role of an active agent in the regulation, compromising the autonomy designed for the agencies in their regulatory activities.
\end{abstract}

Keywords: Regulatory Agencies. Supreme Audit Court. Control. Regulation. 



\section{LISTA DE GRÁFICOS}

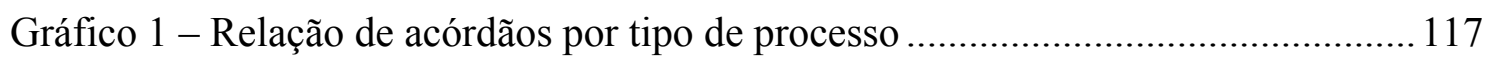

Gráfico 2 - Relação de acórdãos por indexador "subtema" ...................................... 118

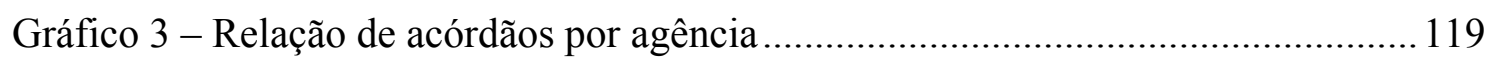

Gráfico 4 - Relação de acolhimento da análise da unidade técnica instrutiva .............. 120

Gráfico 5 - Relação de acórdãos de acordo com o resultado do controle ..................... 121

Gráfico 6 - Função objeto do controle no universo de acórdãos analisados ................. 122 



\section{SUMÁRIO}

1 INTRODUÇÃO: TEMA, HIPÓTESE DE TRABALHO E METODOLOGIA15

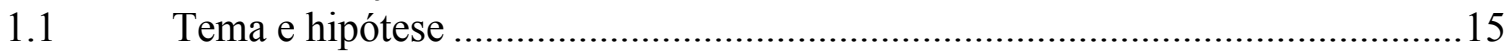

1.2 Delimitação do tema ........................................................................................22

1.3 Metodologia e estrutura da dissertação.................................................................24

2 AS AGÊNCIAS REGULADORAS NO DIREITO BRASILEIRO: A CONFORMAÇÃO DE SUA AUTONOMIA E DE SUAS FUNÇÕES.............27

$2.1 \quad$ Contexto e Notas sobre Seu regime jurídico..........................................................27

2.2 Agências objeto do estudo ………………………........................................

2.2.1 AgÊNCIA NACIONAL DE ENERgIA ElÉtrica (ANEEL) ..........................................31

2.2.2 AgÊNCIA NaCIONAL DE TELECOMUNICAÇÕES (ANATEL) ......................................33

2.2.3 AgÊNCIA NACIONAL Do Petróleo (ANP) ..........................................................34

2.2.4 AgÊNCIA NACIONAL DE AVIAÇÃo CIVIL (ANAC) ...............................................36

2.2.5 AgÊNCIA NaCIONAL DE TRANSPORTES TERRESTRES (ANTT) E AgÊNCIA NACIONAL DE TRANSPORTES AQUAVIÁRIOS (ANTAQ) ........................................38

2.3 As agências e a função regulatória....................................................................... 40

2.4 A Proposta de Independência das Agências Reguladoras como Pressuposto de efetiva regulação.........................................................................................46

2.4.1 O CONTROLE DAS AGÊNCIAS REGULADORAS ……………………………….....49

2.4.2 CONTROLE PELO EXECUTIVO ………………….......................................

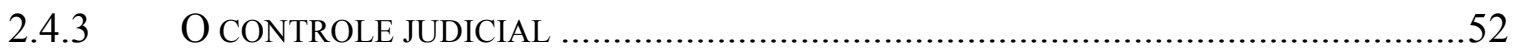

2.4.4 O CONTROLE REGULATÓRIO CRUZADO …………….......................................55

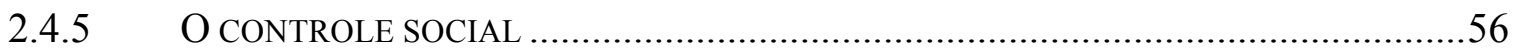

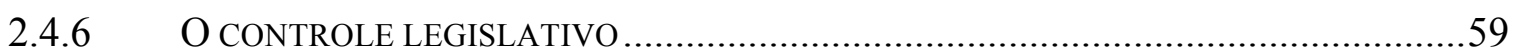

3 O TRIBUNAL DE CONTAS DA UNIÃO E O EXERCÍCIO DO CONTROLE

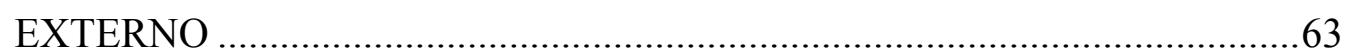

3.1 Controle externo realizado pelo TCU: um imbróglio decorrente da ausência de precisão dos seus limites ..............................................................................66

3.2 O controle externo a cargo do Tribunal de Contas da União................................71

3.2.1 FUNÇ̃̃ES DO TRIBUNAL DE CONTAS DA UNIÃO ..Erro! Indicador não definido.

3.2.1.1 Função fiscalizadora.................................................................................

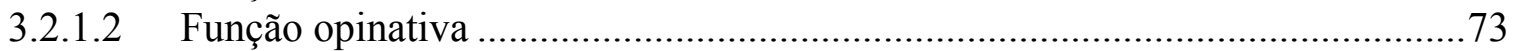

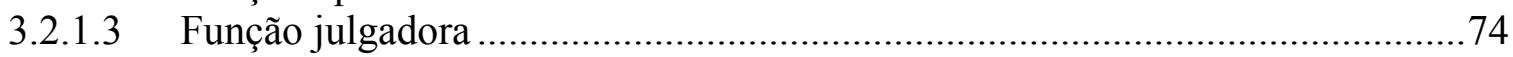

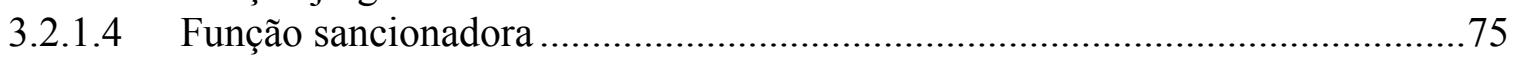

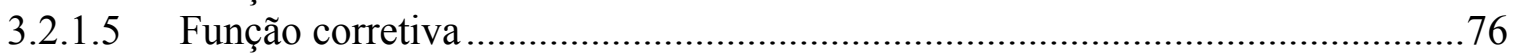

3.2.1.6 Função consultiva........................................................................................76

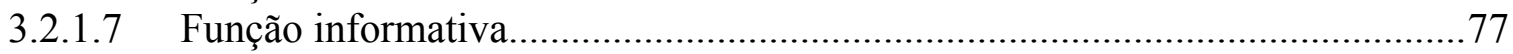

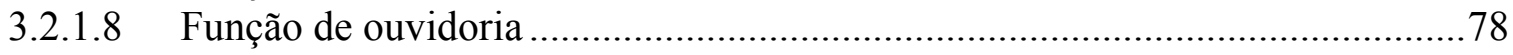

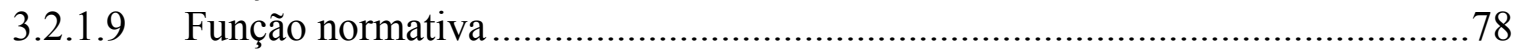

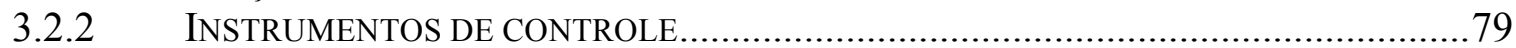

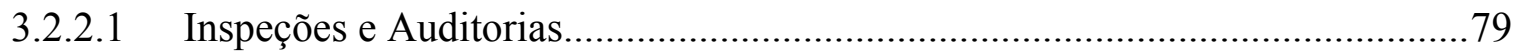

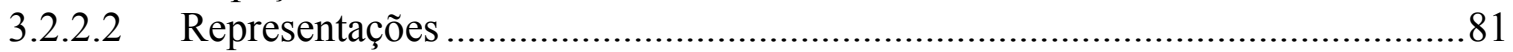

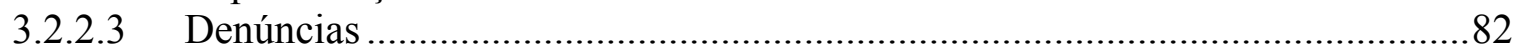

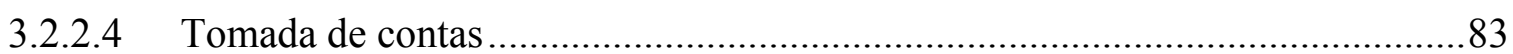

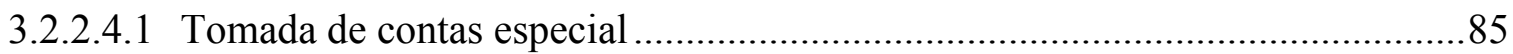

3.2.2.4.2 Emissão de Parecer Prévio sobre as contas anuais dos Chefes do Executivo...86 
3.2.2.4.3 Registros de atos de admissão, aposentadoria, reforma e pensão .88

3.3 Considerações sobre a estrutura organizacional e as competências internas do Tribunal de Contas da União.......................................................................99

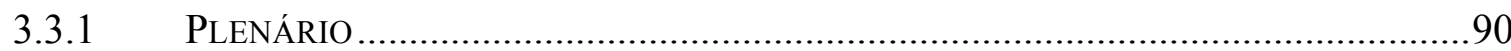

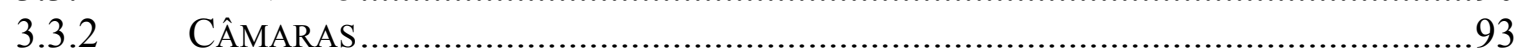

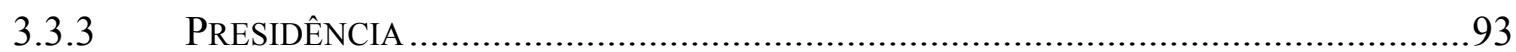

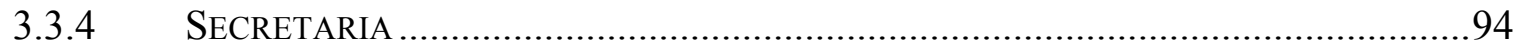

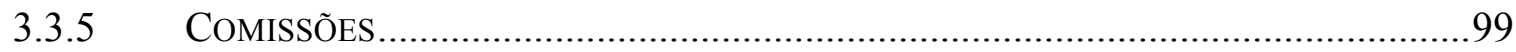

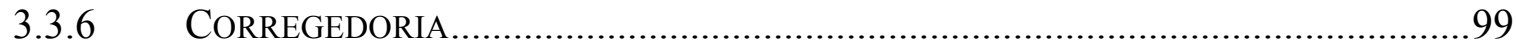

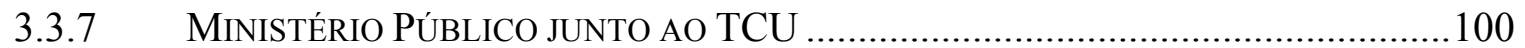

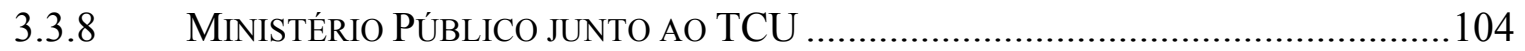

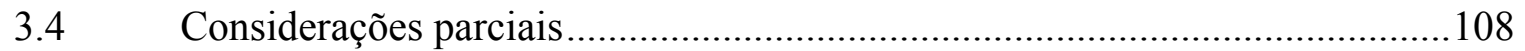

4 A CONCRETIZAÇÃO DO CONTROLE DO TRIBUNAL DE CONTAS DA UNIÃO SOBRE AS AGÊNCIAS REGULADORAS ...................................111

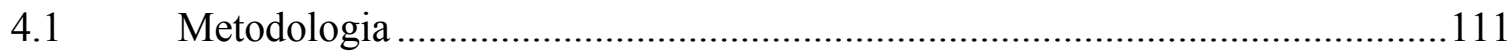

4.2 O controle do TCU sobre as agências reguladoras: panorama dos achados de

4.3 O controle do TCU sobre as agências reguladoras: uma análise qualitativa ...122

4.3.1 PAPEL DO TCU COMO GARANTE DA QUALIDADE REGULATÓRIA ........................122

4.3.2 EVOLUÇÃO DO ENTENDIMENTO DO TCU SOBRE O MODO, A EXTENSÃO E O RESULTADO DO CONTROLE EXERCIDO SOBRE AS AGÊNCIAS REGULADORAS .....124

4.3.2.1 Um esforço de sistematização do controle: o Acórdão 1.703/2004-Plenário .125

4.3.2.2 A discricionariedade é determinada pelo TCU: o Acórdão 1.201/2009-

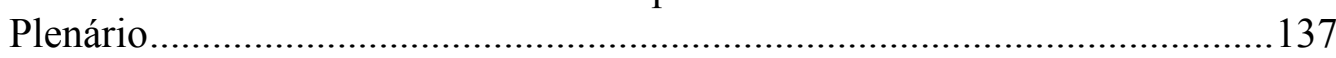

4.3.3 A EXPANSÃO DO CONTROLE POR MEIO DO USO DE CONCEITOS JURÍDICOS INDETERMINADOS E DE SUA COMPETÊNCIA NORMATIVA …................................140

4.3.3.1 Conceitos jurídicos indeterminados ............................................................ 141

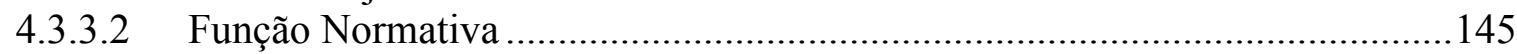

4.3.4 POSICIONAMENTO MAIS INTERVENTIVO DAS UNIDADES TÉCNICAS ....................152

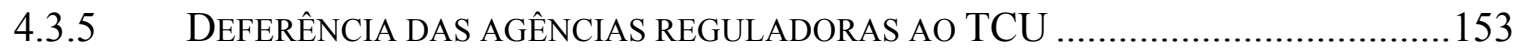

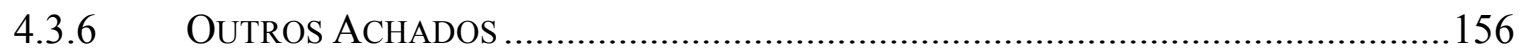

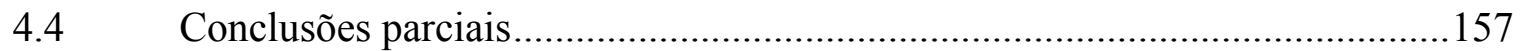

5 CONCLUSÃO - O TRIBUNAL DE CONTAS DA UNIÃO CONFIGURA-SE COMO A “AGÊNCIA DAS AGÊNCIAS"?.................................................163

APÊNDICE A - FUNDAMENTOS NORMATIVOS DA FUNÇÃO REGULATÓRIA177

APÊNDICE B - LEVANTAMENTO DOS DISPOSITIVOS LEGAIS QUE DISCIPLINAM A AUTONOMIA DAS AGÊNCIAS REGULADORAS ......................195

APÊNDICE C - UNIVERSO DE ACÓRDÃOS ANALISADOS ...................................207

APÊNDICE D - SISTEMATIZAÇÃO DOS DADOS DO CONTROLE ......................211 


\section{INTRODUÇÃO: TEMA, HIPÓTESE DE TRABALHO E METODOLOGIA}

\subsection{TEMA E HIPÓTESE}

Esta dissertação pretende responder à seguinte pergunta: a atuação do Tribunal de Contas da União no controle da função regulatória desempenhada pelas agências reguladoras coloca o Tribunal na posição de uma segunda instância regulatória?

Responder a tal questão exige que tratemos das agências, da Corte de Contas e como se dá a interação entre eles.

Vive-se, atualmente, a consolidação do modelo adotado pelo Estado brasileiro a partir da década de 1990 - em que se abandonou um modelo de organização da Administração baseado em instrumentos que viabilizavam a exploração de atividades econômicas e a realização de investimentos diretamente pelo Estado, ou por entidades a ele vinculadas, adotando-se, em seu lugar, um modelo voltado a contemplar mecanismos pelos quais o Estado determinaria as diretrizes, estimularia e controlaria a atuação dos agentes privados, denominado Estado Regulador ${ }^{1}$.

As alterações no perfil no Estado implicaram a mudança da própria Administração Pública, que passou a adotar um modelo gerencial. Houve, nesse sentido, uma forte tendência de dissociar as funções de empresário e regulador, que no modelo anterior eram, via de regra, centralizadas no próprio Estado. Isso posto, a instituição de uma nova burocracia estatal para a regulação de mercados - em grande medida centralizada no modelo de agências reguladoras independentes - levou a uma nítida redefinição dos canais de circulação de poder político para a formulação de políticas públicas para setores

\footnotetext{
Na verdade, o Estado já exercia, de alguma maneira, a regulação, mas não em um sentido específico com se pretende atribuir neste trabalho, Cf.: Considerando-se a regulação como mecanismo de ação do Estado em setores considerados sensiveis da economia destinada a reparar falhas de mercado, (...)é correto afirmar que há um sistema regulatório no Brasil, no mínimo, desde 1965, com a criação do Banco Central do Brasil, por meio da Lei $n^{\circ} 4.595$, de 31 de dezembro de 1964. Não obstante, a regulação independente apenas se firma e se intensifica como mecanismo próprio de ação da Administração Pública a partir da segunda metade dos anos de 1990. E isto ocorre porque a regulação foi o mecanismo encontrado pelo Estado para permitir um amplo processo de liberalização $e$ privatização de atividades antes monopolizadas por agentes estatais, como serviços públicos e monopólios públicos constitucionais. SCHIRATO, Vitor Rhein. A deterioração do sistema regulatório brasileiro. Revista de Direito Público da Economia - RDPE, Belo Horizonte, v. 11, n. 44, out./dez. 2013.
} 
estratégicos da economia brasileira, como o de telecomunicações, energia elétrica, gás e petróleo, transportes etc. ${ }^{2}$

A introdução de entidades dotadas de autonomia em face da Administração Pública direta, e, por consequência, ao menos em tese, imunes às decisões de cunho político, e caracterizadas pela sua tecnicidade, foi a solução encontrada pelo Estado para a atração dos investimentos privados necessários ao sucesso da reforma estatal implementada. ${ }^{3} \mathrm{~A}$ criação de entidades reguladoras independentes sinalizaria segurança jurídica no cenário regulatório brasileiro devido à sua blindagem política ${ }^{4}$, que garantiria a manutenção dos contratos e viabilizariam previsibilidade sobre as normas jurídicas (compromisso regulatório com as regras do jogo). ${ }^{5}$

Embora nos últimos anos outros mecanismos de regulação e intervenção do Estado tenham se fortalecido ${ }^{6}$, não se pode deixar de refletir sobre o progresso e o resultado da adoção deste modelo ${ }^{7}$.

2 MATTOS, Paulo Todescan Lessa. Direito, regulação e economia: estudos para o debate brasileiro. São Paulo: Revista dos Tribunais, 2017. (Coleção capitalismo \& democracia). p. 3.

3 Sobre a criação das agências reguladoras, ver: MARQUES NETO, Floriano de Azevedo. Agências reguladoras independentes: fundamentos e seu regime jurídico. Belo Horizonte: Fórum, 2005. p. 23-42.

4 O que não significa que a economia somente pode ser regulada por agências reguladoras. Como bem expõe Floriano de Azevedo Marques Neto, "não necessariamente os entes incumbidos de regulação carecem de se constituir na configuração jurídica de agências. Entre nós, por exemplo, o primeiro órgão de regulação setorial criado foi o Banco Central do Brasil (...)" (MARQUES NETO, Floriano de Azevedo. Agências reguladoras independentes: fundamentos e seu regime jurídico. Belo Horizonte: Fórum, 2005. p. 51).

5 Nesse sentido: COUTINHO, Diogo Rosenthal. Regulação e redistribuição: a experiência brasileira de universalização das telecomunicações. 2003. Tese (Doutorado em Direito) - o Faculdade de Direito, Universidade de São Paulo, São Paulo. 2003. p. 140.

6 É o que constata, entre outros, Egon Bockmann Moreira: Mas, a toda evidencia, a expansão do modelo regulatório via agências não importou a supressão da endorregulação e respectiva multiplicação de empresas estatais. Nem tornou a regulação o mais soft dos mundos. Tampouco inibiu a voracidade normativa do Estado. Hoje, todas estas perspectivas se conjugam num fenômeno essencialmente múltiplo. Se, antes, era recorrente a imagem de um único pêndulo e seu movimento oscilatório, a revelar o lugar onde, naquele momento, o Estado estava na economia (a ingressar e sair, lenta e periodicamente de determinados modelos regulatórios, mas sempre retornando à sua posição original, antes de partir novamente), atualmente a realidade é outra. O que vivemos é a execução da peça Poème Symphonique pour 100 metronomes, de autoria do compositor húngaro György Ligeti (1923-2006). Nela, são 100 metrônomos (pêndulo oscilante que mede o andamento musical), com velocidades diversas, os quais, muito embora disparados quase que simultaneamente, assumem movimentos em ritmos distintos tornando-se, no começo, indistinguíveis, mas que, com o passar do tempo, assumem a sua diversidade e se emancipam uns dos outros (até, no final, restar um só, antes do silêncio). Cada um desses metrônomos é um (ou mais) dos setores da economia brasileira (em seus três níveis federativos), a instalar ritmos e leituras diversificadas, com inúmeras combinações de entradas e saídas do Estado neste ou naquele setor, desta ou daquela forma. Porventura a única diferença resida no fato de que, no Direito regulatório brasileiro, os pêndulos simultâneos tendem a nunca parar." MOREIRA, Egon Bockmann. Passado, presente e futuro da regulação econômica no Brasil. Revista de Direito Público da Economia - RDPE, Belo Horizonte, v. 11, n. 44, p. 87-118, out./dez. 2013.

7 Ver, nesse sentido: COSTA, Valeriano Mendes Ferreira. A dinâmica institucional da reforma do Estado: um balanço do período FHC. In: ABRÚCIO, Fernando Luiz; LOUREIRO, Maria Rita (Orgs.). O Estado numa era de reformas: os anos FHC - parte 2. Brasília: MP; SEGES, 2002. p. 9-55. 
Isto posto, retome-se que, para o desempenho da função regulatória, nesta dissertação entendida como "modalidade de intervenção estatal direta no domínio econômico ou social destinada à busca do equilíbrio de interesses internos ao sistema regulado e à satisfação de finalidades públicas, condicionada aos limites e parâmetros determinados pelo ordenamento jurídico", , às agências reguladoras foi pensado um desenho institucional próprio, o qual as conferiria autonomia, competência normativa e mandato fixo de seus dirigentes.

A instituição de um regime jurídico especial - variável conforme o conjunto normativo de cada agência ${ }^{9}$ - busca preservar essas entidades de ingerências indevidas, de modo que a função regulatória atenda aos interesses de Estado, e não aos de governo. Procurou-se demarcar, nesse sentido, um espaço de legítima discricionariedade, em que os juízos técnicos sobrepujem as valorações políticas. Constatada a necessidade de se resguardarem as agências reguladoras de ingerências e imposições externas inadequadas, pensou-se em um modelo que lhes assegurasse autonomia político-administrativa e autonomia econômico-financeira. É exatamente o que expõe Vitor Rhein Schirato:

(...) assegurada a existência de um modelo de atuação do Estado equidistante de todos os interesses setoriais (incluindo os políticos) que lhe permitia o encontro de decisões técnicas, equilibradas e imparciais, destinadas a garantir o melhor funcionamento possível do mercado regulado. Sempre, havia a garantia de independência e autonomia das autoridades reguladoras, para assegurar uma blindagem contra invasões políticas nos setores regulados capazes de gerar instabilidade e insegurança ${ }^{10}$.

Desde a instituição das principais agências reguladoras, a doutrina brasileira tem, assim, destacado a relevância dos mecanismos de garantia da sua autonomia e independência. Na medida em que regulam serviços ou atividades de relevância coletiva, a independência dessas entidades seria um pressuposto para o exercício de sua função de

8 MARQUES NETO, Floriano de Azevedo; PALMA, Juliana Bonacorsi de. Parte IV: Regulação. In: DI PIETRO, Maria Sylvia Zanella (Coord.). Tratado de direito administrativo: funções administrativas do Estado. São Paulo: Revista dos Tribunais, 2014. v. 4. p. 511

9 Há iniciativas para a instituição de uma lei geral das Agências Reguladoras, ou Lei Quadro. Nesse sentido, cite-se que já foi aprovado pela Comissão de Constituição e Justiça do Senado (CCJ) projeto da Lei Geral das Agências Reguladoras (PLS) 52/2013. A proposta, que faz parte da Agenda Brasil, estabelece regras relativas à gestão, organização e mecanismos de controle social das agências reguladoras federais e promove ainda ajustes nas leis específicas de criação de cada uma delas. O projeto de lei foi aprovado pela Comissão competente no Senado e, diante da ausência de recursos, foi considerado aprovado pelo Plenário do Senado e, então, encaminhado à Câmara dos Deputados. Na Câmara, foi criada uma Comissão Especial para proferir parecer sobre o projeto de Lei. Disponível em: $<$ http://www25.senado.leg.br/web/atividade/materias/-/materia/111048>. Acesso em: 5 dez. 2017.

10 SCHIRATO, Vitor Rhein. A deterioração do sistema regulatório brasileiro. Revista de Direito Público da Economia - RDPE, Belo Horizonte, v. 11, n. 44, out./dez. 2013. 
forma equidistante em relação aos interesses dos regulados, dos beneficiários da regulação e ainda o próprio poder político. ${ }^{11}$ Mas como teria se concretizado esta independência?

Não obstante a independência de que são dotadas sob a ótica formal, as agências reguladoras não estão isentas de quaisquer tipos de controle ${ }^{12}$ - sujeitam-se, por exemplo, aos controles interno e externo. O primeiro, como é intuitivo, está assentado no mecanismo de controle exercido pela Administração Pública, é a fiscalização que ela exerce sobre os atos e atividades de seus órgãos e das entidades descentralizadas que lhe são vinculadas ${ }^{13}$. De outro lado, resta evidente que a noção de controle externo é a desempenhada por órgãos alheios à Administração Pública, e.g., Poder Legislativo (auxiliado pelo TCU) e Poder Judiciário ${ }^{14}$, além do controle social. Tem-se, como se vê, a projeção do princípio republicano e da convivência harmônica entre os poderes do Estado, ideais albergados pelo ordenamento jurídico pátio no artigo $2^{\circ}$, caput da Constituição Federal.

Vai daí que a previsão de mecanismos de controle sobre as Agências Reguladoras não representa, a priori, incompatibilidade com o regime de independência dessas entidades, consoante explica Alexandre do Santos de Aragão:

\begin{abstract}
Estes controles, além de não serem incompatíveis com a autonomia reforçada que caracteriza as agências, integram o seu próprio conceito. Não seria de se imaginar, realmente, que um órgão ou ente descentralizado, por mais autônomo que fosse, ficasse alheio ao conjunto da Administração Pública. A autonomia não pode servir para isentá-las da obrigação de se inserirem nos planos e diretrizes públicas gerais ${ }^{15}$.
\end{abstract}

11 MARQUES NETO, Floriano de Azevedo. Agências reguladoras independentes: fundamentos e seu regime jurídico. Belo Horizonte: Fórum, 2005. p. 67.

12 Nesse sentido, ver SUNDFELD, Carlos Ari (Coord.). Direito administrativo econômico. 3. tir. São Paulo: Malheiros. 2006. p. 25-26.

13 MEDAUAR, Odete. Controles internos da Administração Pública. Boletim de Direito Administrativo, São Paulo, v. 8, n. 6, 1992. p. 365.

14 Nessa linha, a explanação de Celso Antônio Bandeira de Mello, in verbis: "No Estado de Direito, a Administração Pública assujeita-se a múltiplos controles, no afã de impedir-se que desgarre de seus objetivos, que desatenda as balizas legais e ofenda interesses públicos ou dos particulares. Assim, são concebidos diversos mecanismos para mantê-la dentro das trilhas a que está assujeitada. Tanto são impostos controles que ela própria deve exercitar, em sua intimidade, para obstar ou corrigir comportamentos indevidos praticados nos diversos escalões administrativos de seu corpo orgânico central, como controles que este mesmo corpo orgânico exercita em relação às pessoas jurídicas auxiliares do Estado (autarquias, empresas públicas, sociedades mistas e fundações governamentais). Tais controles envolvem quer aspectos de conveniência e oportunidade quer aspectos de legitimidade. Além disto são previstos controles de legitimidade que devem ser efetuados por outros braços do Estado: Legislativo, por si próprio ou com o auxílio do Tribunal de Contas, e Judiciário, este atuando sob a provocação dos interessados ou do Ministério Público". MELLO, Celso Antônio Bandeira de. Curso de direito administrativo. 27. ed. São Paulo: Malheiros, 2010. p. 935.

15 ARAGÃO, Alexandre Santos de. Agências reguladoras e a evolução do direito administrativo econômico. Rio de Janeiro: Forense, 2002. p. 355. 
Como recorte metodológico, este trabalho buscará analisar o controle externo, exercido pelo Tribunal de Contas da União (TCU), sobre as Agências Reguladoras federais. Nos termos dos artigos 70 e 71 da Constituição Federal, a fiscalização contábil, financeira, orçamentária, operacional e patrimonial da União e das entidades da administração direta e indireta, quanto aos aspectos da legalidade, legitimidade, economicidade, aplicação de subvenções e renúncia de receitas, é exercida pelo Congresso Nacional, com o auxílio do Tribunal de Contas da União. Pretende-se, especificamente, examinar o controle da Corte de Contas sobre as agências reguladoras.

Parte-se do pressuposto de que somente a previsão abstrata de autonomia e independência das Agências Reguladoras não é suficiente à garantia de suas funções institucionalmente concebidas, especialmente quando confrontadas com as competências das demais instituições - no caso em análise, o TCU. Na medida em que a independência das agências não significa a imunidade a qualquer controle, entende-se necessário analisar a atuação e a interação entre as agências reguladoras federais e o TCU sob uma perspectiva dinâmica, lançando olhar para a forma como os comandos normativos são interpretados pela Administração.

Nesse sentido, já bem expuseram Caio Mario da Silva Pereira Neto, Filippo Maria Lancieri e Mateus Piva Adami:

É fundamental estudar a qualidade dessa autonomia - o que exige a
compreensão da interação entre agências e demais instituições do Estado
Democrático de Direito. Em outras palavras: é importante passar de um enfoque
estático - no qual as discussões giram em torno de um mecanismo de garantia
de autonomia e de alocação de competência - para um enfoque institucional
dinâmico - no qual passa a ser relevante a compreensão da interaçãa das
agências com outras instituições e a delimitação do seu espaço de atuação. ${ }^{.6}$.

A partir dessas premissas, pretende-se avaliar como tem se efetivado, na dinâmica de interação institucional travada entre o TCU e as Agências Reguladoras federais, o espaço que foi às últimas reservado para o desempenho da função regulatória.

Entre os atores ${ }^{17}$ do controle da Administração Pública, elegeu-se debruçar os estudos sobre o TCU porque, a uma, trata-se de órgão que figura como um dos principais

16 PEREIRA NETO, Caio Mario da Silva; LANCIERI, Filippo Maria; ADAMI, Mateus Piva. O diálogo institucional das agências reguladoras com os Poderes Executivo, Legislativo e Judiciário: uma proposta de sistematização, In: SUNDFELD, Carlos Ari; ROSILHO, André (Orgs.). Direito da regulação e políticas públicas. São Paulo: Malheiros, 2014. p. 150.

17 Outros atores que atual no controle da atividade das Agências que não serão objeto deste estudo possíveis de serem citados são: Judiciário, o Ombudsman, a própria Administração (em que há polêmica a respeito do cabimento de recurso hierárquico impróprio), a sociedade em geral. 
responsáveis pelo controle dos recursos públicos federais, sendo, portanto, de fundamental importância para o bom funcionamento do Estado e para o sucesso na implementação das mais variadas políticas públicas e regulatórias, na medida em que o sucesso delas depende da gestão e alocação de recursos públicos; e, a duas, porque tem a Corte de Contas apresentado papel central no atual debate das políticas públicas e regulatórias.

Ademais, ainda há poucas pesquisas jurídicas nesta linha ${ }^{18}$. Talvez pela importância e influência do debate nos países de common law que inspiraram a instituição do modelo das agências, muitos são os estudos, por exemplo, que se dedicaram ao controle das Agências Reguladoras pelo Judiciário. Sobre este controle, pesquisa patrocinada pelo Conselho Nacional de Justiça, ${ }^{19}$ voltada à avaliação da eficiência e da certeza jurídica conferidas pela revisão judicial das agências reguladoras revelou que o Judiciário brasileiro corrobora a maioria dos atos questionados, decidindo favoravelmente às agências ${ }^{20}$.

A despeito da ratificação dos atos das agências pelo Judiciário, a conformação da autonomia dessas entidades no plano concreto, para o desempenho da função regulatória, sujeita-se a outros controles e diálogos institucionais que permitem afirmar que a “autonomia das agências é fruto de um espaço de atuação delimitado pelas relações entre os diversos atores institucionais ${ }^{21}$ ". Questiona-se, assim, qual seria o espaço de atuação reservado às entidades reguladoras nas relações travadas entre estas e o Tribunal de Contas da União. Entende-se igualmente pertinente este estudo para buscar compreender o modo como o TCU enxerga seu próprio papel na construção da regulação, da autonomia das agências reguladoras e da relação destas entidades com os usuários, cidadãos e regulados.

Outra motivação do presente trabalho reside no fato de ser, em termos abstratos, inquestionável a relevância do papel a ser desempenhado pelas agências reguladoras. Conforme visto, essas entidades foram, em geral, estabelecidas para proteger o processo de

18 São exemplos de trabalhos voltados essa análise: MONTEIRO, Vera; ROSILHO, André. As agências reguladoras e o controle da regulação pelo Tribunal de Contas da União. In: PEREIRA NETO, Caio Mario da Silva; PINHEIRO, Luís Felipe Valerim. Direito da infraestrutura. São Paulo. Saraiva, 2017. v. 2. p. 27-58. MARQUES NETO, Floriano de Azevedo et al. Reputação institucional e o controle das agências reguladoras pelo Tribunal de Contas da União. Mimeo. Artigo desenvolvido a partir do trabalho de pesquisa do Observatório do Controle da Administração Pública.

19 AZEVEDO, Paulo Furquim de; FERRAZ JUNIOR, Tércio Sampaio; MARANHÃO, Juliano Souza de Albuquerque. As inter-relações entre o processo administrativo e o judicial sob a perspectiva da segurança jurídica do plano da concorrência econômica e da eficácia da regulação pública. São Paulo: USP, 2011. Relatório da pesquisa. Disponível em: <http:/www.cnj.jus.br/images/pesquisasjudiciarias/Publicacoes/relat_pesquisa_usp_edital1_2009.pdf $>$. Acesso em: 15 jul. 2017.

20 Nos termos do estudo, mais de $80 \%$ dos votos de tribunais superiores, decididos em bases substantivas, foram favoráveis às agências.

21 PEREIRA NETO, Caio Mario da Silva; LANCIERI, Filippo Maria; ADAMI, Mateus Piva. O diálogo institucional das agências reguladoras com os Poderes Executivo, Legislativo e Judiciário: uma proposta de sistematização, In: SUNDFELD, Carlos Ari; ROSILHO, André (Orgs.). Direito da regulação e políticas públicas. São Paulo: Malheiros, 2014. p. 164. 
tomada de decisões e a fiscalização nos setores contra a intervenção de políticas de curto prazo. Em condições ideais, prestam-se a equilibrar os interesses de diversos atores do setor regulado (do governo, do setor privado, dos consumidores). ${ }^{22}$ São, assim, protagonistas no modelo regulatório brasileiro.

No entanto, há diversas críticas que podem ser tecidas sobre a forma como tem se efetivado o exercício da função regulatória por tais entidades, havendo quem entenda que se vive conjuntura de deterioração do sistema regulatório ${ }^{23}$. A esse respeito, Vitor Rhein Schirato considera que os pressupostos da implementação do modelo regulatório vigente vêm se deteriorando e, por consequência, vive-se, no âmbito federal, um "declínio" do modelo regulatório pensado a partir da década de 1990.

Aponta o autor que (i) a autonomia das Agências Reguladoras tem sido ameaçada pelo fracionamento de sua competência e pelo aparelhamento político; (ii) o processo decisório das agências é fragilizado em razão da falta de tecnicidade de seus dirigentes e da inobservância às normas de processo; e (iii) os órgãos de controle vêm atuando, com frequência, no campo de discricionariedade que é reservado às agências ${ }^{24}$. Sobre o tema, é constatado que:

\footnotetext{
Os reguladores não detêm o controle dos setores regulados, ficam à mercê de decisões insertas no ambiente político e não detêm mais a necessária distância do centro do poder do político. Ainda, muitas vezes descumprem suas obrigações procedimentais e não fundamentam adequadamente suas decisões. E os órgãos de controle ocupam-se de exercer no lugar dos reguladores a discricionariedade que lhes é exclusiva, em vista de seu mau funcionamento ${ }^{25}$.
}

Diante do papel a ser desempenhado pelas agências reguladoras no cenário institucional brasileiro, entende-se pertinente aprofundar as reflexões sobre o tema, para verificar como se efetiva a autonomia das agências para o exercício de suas funções.

Adota-se, como hipótese de trabalho, a existência de um descompasso entre a atuação de um dos principais atores no atual cenário de controle da Administração - o TCU - e as autoridades reguladoras, na medida em que, no exercício do controle externo,

22 OCDE - Relatório sobre a Reforma Regulatória - Brasil. Fortalecendo a governança para o crescimento. p. 15.

23 Sobre o tema, ver: SCHIRATO, Vitor Rhein. A deterioração do sistema regulatório brasileiro. Revista de Direito Público da Economia - RDPE, Belo Horizonte, v. 11, n. 44, out./dez. 2013; e VÉRAS, Rafael. As falhas na regulação brasileira. Disponível em: $<$ http://www.direitodoestado.com.br/colunistas/Rafael-Veras/as-falhas-da-regulacao-brasileira>. Acesso em: 20 jun. 2016.

24 SCHIRATO, Vitor Rhein. A deterioração do sistema regulatório brasileiro. Revista de Direito Público da Economia - RDPE, Belo Horizonte, v. 11, n. 44, out./dez. 2013.

25 Idem. 
aquele estaria inibindo o espaço reservado, por Lei, às agências para o desempenho da função regulatória.

\subsection{DELIMITAÇÃO DO TEMA}

Para o teste da hipótese foram adotados pressupostos teóricos e delimitações temáticas.

Pretende-se que este trabalho dialogue com uma agenda de pesquisa jurídica que reconhece a importância das instituições e entende que sobreposições, lacunas ou rivalidades de tarefas e responsabilidades em políticas públicas tendem a ser contraproducentes $^{26}$. O objetivo, conforme anteriormente abordado, é realizar um estudo multidisciplinar que não se limite a análises dogmáticas, mas que possibilite o desenvolvimento de diálogo do direito com outras áreas.

Na medida em que não existe uma definição amplamente aceita de "instituição" na literatura $^{27}$, é importante mencionar que se considera, para fins do presente trabalho, que as organizações políticas e os órgãos públicos estão englobados no conceito de instituições ${ }^{28}$.

A importância das instituições tem sido cada vez mais reconhecida tanto pela teoria econômica, que as relaciona ao desenvolvimento econômico ${ }^{29}$, como pelas ciências

26 COUTINHO, Diogo R. O direito no desenvolvimento econômico. Revista Eletrônica de Direito Administrativo Econômico (REDAE), Salvador, n. 28, nov. 2011/jan. 2012. Disponível em: $<$ http://www.direitodoestado.com/revista/REDAE-28-NOVEMBRO-2011-DIOGOCOUTINHO.pdf $>$. Acesso em: 9 nov. 2016.

27 Nesse sentido, Ha-Joon Chang aponta que: "One fundamental difficulty involved in the study of the relationship between institutions and economic development is that there is no widely accepted definition of institutions. If we cannot agree on what we mean by institutions, it is difficult to imagine that we would have a consensus on what they are supposed to do, such as promoting economic development. When we have differences over the very definition of the term 'institutions', it is not surprising that we do not have an agreement on the relationship between institutions and economic development". CHANG, Ha-Joon. Understanding the Relationship between Institutions and Economic Development. UNUWIDER Discussion Paper 2006/05.

28 Consoante aduz Ha-Joon Chang, para um estudo aprofundado sobre a definição de instituições, ver: VAN ARKADIE, B. The Role of Institutions in Development in the World Bank. Proceedings of the World Bank Annual Conference on Development Economics: 1989. Washington, DC: World Bank, 1990. Ao indicar a leitura, Chang faz a seguinte consideração: "For a very informative early discussion of the definitional problem, see van Arkadie (1990). Van Arkadie points out that institutions are used to mean both the 'rules of the game' and the 'organisations'. While the former sense of the term has become more prevalent since the time when van Arkadie wrote the article, we still use terms like the Bretton Woods Institutions, which uses the word institution in the latter sense". CHANG, Ha-Joon. Understanding the Relationship between Institutions and Economic Development. UNU-WIDER Discussion Paper 2006/05, p. 2.

29 As instituições ganham relevo nos estudos de Douglass North e mais recentemente nos seguintes estudos: RODRIK, Dani; SUBRAMANIAN, A.; TREBBI, F. Institutions Rule: The Primacy Of Institutions Over Geography And Integration In Economic Development. NBER WORKING, 2002. Disponível em: $<$ https://www.imf.org/external/pubs/ft/wp/2002/wp02189.pdf>. Acesso em: 14 jan. 2018; e CHANG, Ha- 
políticas, na análise de políticas públicas ${ }^{30}$. No campo do direito, há aqueles que as estudam sob a perspectiva da influência do direito para o desenvolvimento econômico, estimulando a produção de pesquisas empíricas sobre o tema:

[...] não há dúvidas de que as instituições têm um papel muito importante no desenvolvimento. Entre outras coisas, elas organizam práticas de administração de políticas, conectam atores, criam conhecimento, alinham incentivos e permitem que expectativas e sentidos comuns sejam partilhados. As instituições redistribuem renda, oferecem oportunidades, coordenam decisões, promovem inovação, competição e influenciam custos. ${ }^{31}$

Nesse sentido, a pesquisa do presente trabalho recai sobre a descrição e a análise de instituições relevantes no cenário regulatório brasileiro, ligadas sob diversos aspectos ao processo de governança e implementação de políticas regulatórias e políticas públicas: o TCU e as agências reguladoras federais.

É abordado o modo como as normas jurídicas moldaram e conformaram essas entidades no intuito de constatar se esses elementos atentam e colaboram para a dinâmica do desempenho de suas funções. Em outras palavras, o trabalho busca expor os principais aspectos do arcabouço jurídico regulamentador das competências das agências reguladoras e do TCU, bem como investigar se as interações entre essas entidades tendem a fortalecêlas ou debilitá-las, e averiguar em que medida isso se procede. Para tanto, já foi dito anteriormente, a análise da jurisprudência do TCU é ferramenta de pesquisa.

Essa análise se faz sobretudo pela perspectiva do exercício da função regulatória, bem como pela perspectiva do exercício de seu controle, consagrado na jurisprudência do TCU. Saliente-se, nessa linha, que o estudo não se debruça, efetivamente, sobre os efeitos concretos de cada caso analisado.

Outro recorte adotado diz respeito às entidades sobre os quais a dissertação se debruça. Escolheu-se esfera federal como um primeiro filtro, selecionando-se, a partir dele, o TCU e agências reguladoras federais. Além disso, foram eleitas as seguintes agências: Anac, Anatel, Aneel, ANP, Antaq e ANTT.

Joon. Understanding the Relationship between Institutions and Economic Development. UNU-WIDER Discussion Paper 2006/05.

30 Sobre a perspectiva das ciências políticas, ver: HALL, P. A.; TAYLOR, R. C. As três versões do neoinstitucionalismo. Lua Nova, v. 58, p. 1-32, 2003.

31 COUTINHO, Diogo R. O direito no desenvolvimento econômico. Revista Eletrônica de Direito Administrativo Econômico (REDAE), Salvador, n. 28, nov. 2011/jan. 2012. Disponível em: $<$ http://www.direitodoestado.com/revista/REDAE-28-NOVEMBRO-2011-DIOGOCOUTINHO.pdf>. Acesso em: 9 nov. 2016. Grifo nosso. 


\subsection{Metodologia E ESTRUTURA DA DISSERTAÇÃo}

Conforme já exposto, a dissertação tem por objetivo investigar qual a efetiva autonomia das agências reguladoras quando conjugadas as funções pensadas pela doutrina e atribuídas a essas entidades pelo ordenamento jurídico aos efeitos do controle externo exercido pelo TCU.

Para a consecução desse objetivo, o trabalho divide-se em duas etapas: (i) posicionamento em relação às entidades abordadas na dissertação, por meio da exposição dos principais aspectos de seu arcabouço jurídico-institucional, de modo a situar o debate relativo ao diálogo institucional entre a Corte de Contas e as agências reguladoras; (ii) análise da interação entre as entidades mencionadas, com o intuito de verificar como, na dinâmica do controle das agências reguladoras pelo TCU, se concretizam as competências do TCU e o exercício da função regulatória pelas agências.

A dissertação estrutura-se em três capítulos, além deste e da conclusão.

O capítulo 2 aborda as características e os pressupostos teóricos do modelo institucional das agências reguladoras federais, conjugando-os, horizontalmente, à disciplina normativa regente da matéria. Passa-se, em seguida, à apresentação de cada uma das agências reguladoras objeto da dissertação, por meio da exposição de suas principais competências. É então apresentada a tipologia adotada para a classificação do plexo de atribuições que compõem a função regulatória enquanto modalidade de intervenção estatal direta no domínio econômico ou social destinada à busca do equilíbrio de interesses internos ao sistema regulado e à satisfação de finalidades públicas, condicionada aos limites e aos parâmetros determinados pelo ordenamento jurídico — conceito central ao presente estudo ${ }^{32}$.

O terceiro capítulo cuida da abordagem do controle externo realizado pelo TCU. Sem a pretensão de esgotar o debate sobre as suas competências, diante da ausência de clareza e objetividade da delimitação do controle externo exercido pelo órgão, pretende-se expor um panorama geral das normas que conformaram o regime jurídico da Corte de Contas no Brasil, apontando as principais funções por ele desempenhadas e, sem esgotar o debate, apresentar alguns aspectos polêmicos quanto ao modo como se procede ao desempenho dessas atribuições, especialmente quanto ao âmbito e ao objeto do controle do

\footnotetext{
${ }^{32}$ MARQUES NETO, Floriano de Azevedo; PALMA, Juliana Bonacorsi de. Parte IV: Regulação. In: DI PIETRO, Maria Sylvia Zanella (Coord.). Tratado de direito administrativo: funções administrativas do Estado. São Paulo: Revista dos Tribunais, 2014. v. 4. p. 511.
} 
TCU. A partir da análise normativa, são igualmente abordados os principais instrumentos de controle do tribunal e as características de sua estrutura organizacional, incluindo notas sobre a sua divisão interna de competências.

Mas, afinal, como se efetiva o controle das agências reguladoras pelo TCU? A partir de análise da jurisprudência da Corte de Contas, a proposta do capítulo 4 é apresentar a maneira pela qual, na prática, se interpreta o arcabouço jurídico regulamentador das competências das agências reguladoras e do TCU, por meio do exame do controle exercido por este sobre aquelas. A análise dessa interação possibilita testar a hipótese de que, no exercício do controle externo sobre as agências reguladoras, o TCU assume o papel de um agente ativo no exercício da função regulatória, o que comprometeria a autonomia arquitetada para essas entidades quando da concepção do modelo regulatório implementado com a reforma do Estado.

Na conclusão do trabalho são tecidas considerações sobre os achados de pesquisa e o seu impacto no teste da hipótese, buscando-se responder à seguinte questão: na prática, a atuação do TCU no controle da função regulatória desempenhada pelas agências coloca o tribunal na posição de uma segunda instância regulatória? 


\section{CONCLUSÃO - O TRIBUNAL DE CONTAS DA UNIÃO CONFIGURA-SE COMO A "AGÊNCIA DAS AGÊNCIAS"?}

Na abertura desta dissertação foi apresentada a seguinte pergunta: a atuação do Tribunal de Contas da União no controle da função regulatória desempenhada pelas agências reguladoras coloca o Tribunal na posição de uma segunda instância regulatória?

A resposta é sim. Porém, o TCU atua como se fosse uma segunda instância regulatória que também age de ofício e seletivamente.

Como apresentado nos capítulos 1 e 2 deste trabalho, às agências estudas (Anac, Anatel, Aneel, ANP, Antaq e ANTT) conferiu-se um desenho institucional específico e competências que se inserem âmbito da função regulatória. Com algumas particularidades, as leis que instituíram essas entidades estabeleceram mecanismos destinados a garantir o desempenho da função regulatória com independência e de forma equidistante em relação aos interesses dos regulados, dos beneficiários da regulação e ainda o próprio poder político. Porém, enquanto entidades da Administração Pública, as agências reguladoras não estão imunes à incidência de controles.

Em relação ao TCU, foi possível identificar que diante da ausência de clareza e objetividade das normas constantes dos artigos 70 e 71 da Constituição Federal, há divergências quanto aos limites das competências da Corte de Contas, sobretudo em relação a quais seriam os possíveis resultados do controle. Além disso, a partir de uma análise sistematizada de suas funções, é inegável a importância no exercício do controle da Administração. Para proceder à sua missão, o Tribunal conta com uma considerável estrutura técnica e dispõe de diversos instrumentos de controle, dos quais se destacam as auditorias e inspeções. Questiona-se, sobretudo, se poderia o TCU emitir comandos vinculativos como resultado do controle realizado por meio das auditorias operacionais. Apesar de oposição de considerável parte da doutrina, da análise de jurisprudência empreendida no capítulo 4, constatou-se que o Tribunal se enxerga competente para proferir tanto recomendações quanto determinações por meio das auditorias operacionais, quando verificadas irregularidades de qualquer natureza. $\mathrm{Na}$ prática, tanto as recomendações quanto as determinações possuem alta carga vinculativa.

Afirma-se que o TCU pode agir de ofício na medida em que as inspeções e auditorias podem também ser manejadas por iniciativa do próprio órgão. E, por meio destes procedimentos, são por vezes identificadas potenciais irregularidades que ou 
resultam em comandos às agências reguladoras no âmbito das próprias auditorias ou desdobram-se em representações e denúncias.

De outro lado, a necessária seletividade na escolha dos objetos a serem fiscalizados foi reconhecida pela própria Corte, quando da revogação da IN $n^{0} 43 / 2002$, que disciplinava o acompanhamento pelo Tribunal de Contas da União dos processos de revisão tarifária periódica dos contratos de concessão dos serviços de distribuição de energia elétrica, sob fundamento de que já haveria "baixo risco [...] pelo atual processo de revisão tarifária realizado pela Agência Nacional de Energia Elétrica (Aneel)". Diante do volume de temas, cabe ao Tribunal definir suas prioridades.

Nessa linha, os achados de pesquisa do capítulo 4 levaram às seguintes constatações:

(i) Diversos enunciados constantes da busca pela jurisprudência selecionada referiam-se a uma natureza de segunda ordem do controle exercido pelo TCU sobre as agências. Contudo, a análise atenta dos julgados permitiu constatar que os resultados do controle iam sempre além disso.

(ii) O Tribunal preocupa-se com a qualidade da regulação e dos serviços regulados, e entende apresentar potencial para a disseminação de boas práticas de regulação. As auditorias operacionais são o principal instrumento para isso.

(iii) Uma tentativa de sistematização da disciplina do controle do TCU sobre as agências reguladoras, por meio do Acórdão 1.703/2004-Plenário. A partir deste julgado, reiterou-se o entendimento de que o tribunal teria competência para o exercício do controle tanto dos atos situados na áreameio das agências como dos atos finalísticos das agências, mas em relação a estes últimos a atuação do tribunal seria complementar, para não ocorrer a substituição das agências reguladoras pelo órgão de controle. O resultado do exercício desse controle sobre as atividades finalísticas das agências seriam recomendações sobre providências destinadas a tornar mais eficiente a atuação finalística e discricionária das agências reguladoras, exceto eventual constatação de inobservância de norma jurídica, que demandaria a emissão de determinações para a adoção das medidas necessárias à sua correção.

(iv) Esses parâmetros, apesar de contemplados em outras decisões, sofreram um revés com o Acórdão 1.201/2009, por meio do qual foi validado entendimento de que independentemente da classificação do ato, vinculado 
ou discricionário, caberia ao TCU prolatar determinações quando verificado que o ato não atingiu a finalidade da norma e o interesse público.

(v) Não obstante essa sutil mudança de entendimento, o discurso formalmente adotado pela Corte de Contas manteve-se no sentido de que a fiscalização do TCU sobre a atuação das agências reguladoras deveria ser de "segunda ordem", para que a Corte não se substituísse à entidade reguladora. No entanto, além de alteração dos efetivos desdobramentos conferidos a esse discurso, constatou-se flexibilização dos limites desse controle. Na prática, o TCU se vale de conceitos jurídicos indeterminados e de sua função normativa para fundamentar um controle ativo de aspectos próprios da função regulatória. Quando projetados os resultados do controle, constata-se que o TCU controla amplamente aquilo que legalmente foi atribuído às agências reguladoras, emitindo determinações e recomendações (comandos que acabam apresentando resultados muito semelhantes), sob o pálio de um controle de eficiência, legitimidade, economicidade ou adequação ao ordenamento jurídico.

(vi) Os pareceres das unidades técnicas são largamente considerados pelos ministros em seus votos. Todas as vezes em que houve discordância do Plenário ou Relator em relação à análise ou à proposta de encaminhamento da unidade técnica, esta apresentou postura mais interventiva em relação ao controle da função regulatória. Ainda que as unidades técnicas estejam em constante diálogo com as agências reguladoras, por meio da solicitação de informações, documentos e realização de auditorias, esse achado se revela sensível na medida em que são as agências reguladoras entidades dotadas, ao menos no plano legal, de permeabilidade ao setor, sobretudo por meio: (a) da participação de membros da sociedade em conselhos superiores ou conselhos consultivos das agências; (b) da participação nos processos decisórios em consultas e audiências públicas; (c) da formulação de denúncias ou reclamações, cabendo à Agência Reguladora averiguar os fatos e tomar medidas administrativas aptas a corrigir o ilícito e punir o agente ou regulado responsável; (d) da participação popular em ouvidorias, além de outros mecanismos de pressão. Nessa linha, as agências teriam maior legitimidade para definir a regulação, bem como maior aderência às necessidades do setor. 
(vii) Há baixo nível de questionamento das agências reguladoras em relação à competência do TCU, quando do desempenho do seu controle externo, o que pode ser explicado, principalmente: (a) por possível reconhecimento da legitimidade da atuação do TCU pelas agências; (b) receio de responsabilização pessoal dos gestores; (c) a agência em ter sua prestação de contas julgada irregular.

Não se está a defender que as decisões técnicas das agências reguladoras sejam isentas de controle ou superiores àquelas exaradas pelo TCU. Na verdade, reconhece-se que o Tribunal apresenta um papel relevante no cenário do controle e aprimoramento da gestão pública. A crítica, porém, recai sobre dois principais aspectos: o modo como o controle é exercido e a insegurança jurídica que dele decorre.

Parte-se da premissa de que no controle da eficiência regulatória por meio de auditorias operacionais, seria atribuição da Corte de Contas a análise, publicação da auditoria e informação à entidade fiscalizada, sem qualquer tipo de vinculação ao posicionamento do controlador. Ao impor decisões de natureza eminentemente técnica e acompanhar a execução destas por meio de procedimentos específicos, o TCU impacta significativamente a autonomia funcional das agências reguladoras.

Essa postura do TCU produz efeitos notáveis. O maior deles é a submissão das agências a uma forma de tutela do órgão de controle externo que, ao final, erode a estrutura funcional da regulação na medida em que a sua definição final passa a ditada pela Corte de Contas. Trata-se de risco do deslocamento da função regulatória das agências para o TCU, que resulta em insegurança jurídica. 


\section{REFERÊNCIAS}

AGÊNCIA NACIONAL DE ENERGIA ELÉTRICA. Relatório Aneel 10 anos. Brasília: Aneel, 2008. Disponível em: <http://www2.aneel.gov.br/arquivos/pdf/aneel_10_anos.pdf $>$. Acesso em: 5 set. 2017.

ALMEIDA, Fernando Dias Menezes de. Considerações sobre a "regulação" no direito positivo brasileiro. Revista de Direito Público da Economia, Belo Horizonte, v. 12, p. 69-94, 2005.

ALMEIDA, Fernando Dias Menezes; ZAGO, Mariana Augusta dos Santos. Controle de políticas públicas pelo Poder Judiciário: breves ideias a partir do modo de estruturação da jurisdição. In: SUNDFELD, Carlos Ari; ROSILHO, André (Orgs.). Direito da regulação e políticas públicas. São Paulo: Malheiros, 2014.

ALVIM, Eduardo Arruda; TAVOLARO, Luiz Antonio (Org.). Licitação e contratos administrativos: uma visão atual à luz dos tribunais de contas. Curitiba: Juruá, 2006.

ARAGÃO, Alexandre Santos de. Agências reguladoras e a evolução do direito administrativo econômico. 3. ed. Rio de Janeiro: Forense, 2013.

ARAGÃO, Alexandre Santos de. Agências reguladoras: algumas perplexidades e desmistificações. Interesse Público, Belo Horizonte, n. 51, ano 10, set./out. 2008 Disponível em: $<$ http://www.bidforum.com.br/PDI0006.aspx?pdiCntd=55459 $>$. Acesso em: 24 jun. 2017.

ARAGÃO, Alexandre Santos de. As agências reguladoras e a evolução do direito administrativo econômico. 2. tir. Rio de Janeiro: Forense, 2004.

ARAGÃO, Alexandre Santos de. Atividades privadas regulamentadas: autorização administrativa, poder de polícia e regulação. Revista de Direito Público da Economia RDPE, Belo Horizonte, v. 3, n. 10, p. 9-48, abr./jun. 2005.

ARAGÃO, Alexandre Santos de. Agências reguladoras e a evolução do direito administrativo econômico. Rio de Janeiro: Forense, 2002.

ARAGÃO, Alexandre Santos de; MARQUES NETO, Floriano de Azevedo (Coords.). Direito administrativo e seus novos paradigmas. Belo Horizonte: Fórum, 2009.

AZEVEDO, Paulo Furquim de; FERRAZ JUNIOR, Tércio Sampaio; MARANHÃO, Juliano Souza de Albuquerque. As inter-relações entre o processo administrativo e o judicial sob a perspectiva da segurança jurídica do plano da concorrência econômica e da eficácia da regulação pública. São Paulo: USP, 2011. Relatório da pesquisa. Disponível em: <http://www.cnj.jus.br/images/pesquisasjudiciarias/Publicacoes/relat_pesquisa_usp_edital1_2009.pdf>. Acesso em: 15 jul. 2017. 
BARROSO, Luís Roberto. Apontamentos sobre as agências reguladoras. In:

FIGUEIREDO, Marcelo (Coord.). Direito e regulação no Brasil e nos EUA. São Paulo:

Malheiros, 2004.

BARROSO, Luis Roberto. Tribunal de Contas: algumas incompetências. RDA, v. 203, p. 138, jan./mar. 1996.

BRESSER-PEREIRA, Luiz Carlos. Da administração pública democrática à gerencial. In: BRESSER-PEREIRA, Luiz Carlos; SPINK, Peter (Orgs.). Reforma do Estado e administração pública gerencial. 2. ed. Rio de Janeiro: Fundação Getulio Vargas, 1998. p. $237-270$.

BUCCI, Maria Paula Dallari. Direito administrativo e políticas públicas. São Paulo: Saraiva, 2002.

CÂMARA, Jacintho Arruda. As autorizações da Lei Geral de Telecomunicações e a teoria geral do direito administrativo. Revista de Informática e Telecomunicações - RDIT, Belo Horizonte, v. 2, n. 3, p. 56-68, jul./dez. 2007.

CASSESE, Sabino. Le transformazioni del diritto amministrativo dal XIX al XXI secolo. Rivista Trimestrale di Diritto Pubblico, 2002. p.28.

CHANG, Ha-Joon. Understanding the Relationship between Institutions and Economic Development. UNU-WIDER Discussion Paper 2006/05.

CHEVALLIER, Jacques. O Estado pós-moderno, Belo Horizonte: Fórum, 2009.

COSTA, Valeriano Mendes Ferreira. A dinâmica institucional da reforma do Estado: um balanço do período FHC. In: ABRÚCIO, Fernando Luiz; LOUREIRO, Maria Rita (Orgs.). O Estado numa era de reformas: os anos FHC - parte 2. Brasília: MP; SEGES, 2002. p. 9-55.

COUTINHO, Diogo R. O direito nas políticas públicas. In: MARQUES, Eduardo; FARIA,Carlos A. Pimenta de (Orgs.). Política pública como campo disciplinar. São Paulo: Edunesp; Fiocruz, 2013.

COUTINHO, Diogo R. O direito no desenvolvimento econômico. Revista Eletrônica de Direito Administrativo Econômico (REDAE), Salvador, n. 28, nov. 2011/jan. 2012. Disponível em: <http:/www.direitodoestado.com/revista/REDAE-28-NOVEMBRO-2011DIOGOCOUTINHO.pdf $>$. Acesso em: 9 nov. 2016.

COUTINHO, Diogo Rosenthal. Regulação e redistribuição: a experiência brasileira de universalização das telecomunicações. 2003. Tese (Doutorado em Direito) - o Faculdade de Direito, Universidade de São Paulo, São Paulo. 2003.

DAL POZZO, Gabriela Tomaselli Bresser Pereira. As funções do Tribunal de Contas e o Estado de direito. Belo Horizonte: Fórum, 2010.

DI PIETRO, Maria Sylvia Zanella. Privatização e o novo exercício de funções públicas por particulares. In: Uma avaliação das tendências contemporâneas do direito 
administrativo: obra em homenagem a Eduardo García de Enterría. Rio de Janeiro: Renovar, 2003.

ENGISCH, Karl. Introdução ao pensamento jurídico. Traduzido por João Baptista Machado. Lisboa: Fundação Calouste Gulbernkian, 2008.

FAGUNDES, Maria Aparecida de Almeida Pinto S. Os novos rumos do direito da eletricidade. Revista de Direito Administrativo - RDA, n. 224, p. 1-29, abr./jun. 2001.

FERNANDES, Jorge Ulysses Jacoby. Tomada de contas especial: processo e procedimento na Administração Pública e nos Tribunais de Contas. Belo Horizonte: Fórum, 2015.

FERNANDES, Jorge Ulysses Jacoby. Tribunais de Contas no Brasil: jurisdição e competência. Belo Horizonte: Fórum, 2003.

FERRAZ JÚNIOR, Tércio Sampaio. Introdução ao estudo do direito: técnica, decisão, dominação. $5^{\mathrm{a}}$ ed., $2^{\mathrm{a}}$ reimpr. São Paulo: Atlas, 2007.

FIGUEIREDO, Lúcia Valle. Direito público: estudos. Belo Horizonte: Fórum, 2007.

GARCÍA DE ENTERRIA, Eduardo; FERNANDÉZ, Tomás-Ramón. Curso de derecho administrativo. 6. ed. Madrid: Civitas, 1999.

GIANNINI, Massimo Severo. Istitutzioni di diritto amministrativo. Giuffré, 2000.

GONÇALVES, Pedro. Direito administrativo da regulação. In: Regulação, electricidade e telecomunicações: estudos de direito administrativo da regulação. Coimbra: Coimbra, 2008.

GROTI, Dinorá Adelaide Musetti. Teorias do serviço público e suas transformações. In: SUNDFELD, Carlos Ari. Direito administrativo econômico. São Paulo: Malheiros, 2000. p. 39-71.

GUERRA, Sérgio. Discricionariedade, regulação e reflexividade: uma nova teoria sobre as escolhas administrativas. Belo Horizonte: Fórum, 2013.

GUIMARÃES, Bernardo Strobel. A regulação como função de direito administrativo. 2007. 159 p. Dissertação (Mestrado em Direito) - Faculdade de Direito, Universidade de São Paulo, São Paulo, 2007.

GUSTIN, Miracy Barbosa de Sousa; DIAS, Maria Tereza Fonseca. Repensando a pesquisa jurídica: teoria e prática. 2. ed. Belo Horizonte: Del Rey, 2006.

HALL, P. A.; TAYLOR, R. C. As três versões do neoinstitucionalismo. Lua Nova, v. 58, p. 1-32, 2003.

JUSTEN FILHO, Marçal. Agências reguladoras e democracia: existe um déficit democrático na "regulação independente"? In: ARAGÃO, Alexandre Santos de (Coord.). O poder normativo das agências reguladoras. Belo Horizonte: Fórum, 2008. 
JUSTEN FILHO, Marçal. Curso de direito administrativo. 10. ed. São Paulo: Revista dos Tribunais, 2014.

JUSTEN FILHO, Marçal. O direito das agências reguladoras independentes. São Paulo: Dialética, 2002.

KAAHN, Alfred E. The Economics of Regulation: Principles and Institutions. Cambridge, MA: MIT Press, 1988.

KLEIN, Aline Lícia; MARQUES NETO, Floriano de Azevedo. Funções administrativas do Estado. São Paulo: Revista dos Tribunais, 2014. (Tratado de direito administrativo, v. 4).

LIMA, Luiz Henrique. Controle externo: teoria e jurisprudência para os tribunais de contas. 6. ed. Rio de Janeiro: Método, 2015.

MANZETTI, L. (Ed.). Regulatory Policy in Latin America: Post Privatization Realities. North South Center, 2000.

MARANHÃO, Juliano Souza de Albuquerque. A revisão judicial de decisões das agências regulatórias: jurisdição exclusiva? In: PRADO, Mariana Mota (Org.). O Judiciário e o Estado regulador brasileiro. São Paulo: FGV Direito SP, 2016.

MARQUES NETO, Floriano de Azevedo et al. Reputação institucional e o controle das agências reguladoras pelo Tribunal de Contas da União. Mimeo.

MARQUES NETO, Floriano de Azevedo. A nova regulamentação dos serviços públicos. Revista Eletrônica de Direito Administrativo, n. 1, fev./abr. 2005.

MARQUES NETO, Floriano de Azevedo. A superação do ato administrativo autista. In: MEDAUAR, Odete; SCHIRATO, Vitor Rhein (Coords.). Os caminhos do ato administrativo. São Paulo: Revista dos Tribunais, 2011. p. 89-113.

MARQUES NETO, Floriano de Azevedo. Agências reguladoras independentes: fundamentos e seu regime jurídico. Belo Horizonte: Fórum, 2005.

MARQUES NETO, Floriano de Azevedo. Bens reversíveis nas concessões do setor de telecomunicações. Revista de Direito Público da Economia, Belo Horizonte, n. 8, out./dez. 2004.

MARQUES NETO, Floriano de Azevedo. Discricionariedade e regulação setorial: o caso do controle dos atos de concentração por regulador setorial. In: ARAGÃO, Alexandre Santos de (Org.). O poder normativo das agências reguladoras. Rio de Janeiro: Forense, 2006. p. 569-604.

MARQUES NETO, Floriano de Azevedo. Estado da arte do controle da Administração Pública no Brasil e na União Europeia. Disponível em:

$<$ http://www.gespublica.gov.br/sites/default/files/documentos/floriano_081215_estado_da_arte_do_controle_interno_ue_com.pdf $>$. Acesso em: 8 jan. 2018. 
MARQUES NETO, Floriano de Azevedo. Finalidades e fundamentos da moderna regulação econômica. Fórum Administrativo - FA, Belo Horizonte, v. 9, n. 100, jun. 2009.

MARQUES NETO, Floriano de Azevedo. Limites à abrangência e à intensidade da regulação estatal. Revista de Direito Público da Economia, Belo Horizonte, v. 1, jan./mar. 2003.

MARQUES NETO, Floriano de Azevedo. Os grandes desafios do controle da Administração Pública. In: MODESTO, Paulo (Coord.). Nova organização administrativa brasileira. Belo Horizonte: Fórum, 2009. p. 195-226.

MARQUES NETO, Floriano de Azevedo. Regulação estatal e interesses públicos. São Paulo: Malheiros, 2002.

MARQUES NETO, Floriano de Azevedo; PALMA, Juliana Bonacorsi de. Parte IV: Regulação. In: DI PIETRO, Maria Sylvia Zanella (Coord.). Tratado de direito administrativo: funções administrativas do Estado. São Paulo: Revista dos Tribunais, 2014. v. 4. p. 576-577.

MARQUES NETO, Floriano de Azevedo; PALMA, Juliana Bonacorsi. Os sete impasses da administração pública no Brasil. In: PEREZ, Marcos Augusto; SOUZA, Rodrigo Pagani de. Controle da administração pública. Belo Horizonte: Fórum, 2017.

MARQUES NETO, Floriano Peixoto de Azevedo. A nova regulação estatal e as agências reguladoras independentes. In: SUNDFELD, Carlos Ari (Org.). Direito administrativo econômico. São Paulo: Malheiros, 2002.

MASAGÃO, Mário. Curso de direito administrativo. São Paulo: Revista dos Tribunais, 1974.

MASHAW, Jerry. Prodelegation: Why Administrators Should Make Political Decisions. Journal of Law, Economics, \& Organization, v. 1, n. 1, p. 81-100, 1985.

MATTOS, Paulo Todescan Lessa. Direito, regulação e economia: estudos para o debate brasileiro. São Paulo: Revista dos Tribunais, 2017. (Coleção capitalismo \& democracia).

MATTOS, Paulo Todescan. O novo Estado regulador no Brasil: eficiência e legitimidade. São Paulo: Singular, 2006.

MEDAUAR, Odete. Controles internos da Administração Pública. Boletim de Direito Administrativo, São Paulo, v. 8, n. 6, 1992.

MEDAUAR, Odete. Direito administrativo moderno. 18. ed. São Paulo: RT, 2014.

MEDAUAR, Odete. Serviços públicos e serviços de interesse econômico geral. In: MOREIRA NETO, Diogo Figueiredo (Org.). Uma avaliação das tendências do direito administrativo. Rio de Janeiro: Renovar, 2003. 
MEDAUAR, Odete. Controle administrativo das autarquias. São Paulo: Bushatsky, 1976.

MEDAUAR, Odete. Controle da administração pública. 2. ed. São Paulo: Revista dos Tribunais, 2012.

MEDAUAR, Odete. Direito administrativo em evolução. 2. ed. São Paulo: Revista dos Tribunais, 2003.

MEIRELLES, Hely Lopes. Direito administrativo brasileiro. 27. ed. São Paulo: Malheiros, 2002.

MELLO, Celso Antônio Bandeira de. Curso de direito administrativo. 27. ed. São Paulo: Malheiros, 2010.

MELLO, Celso Antônio Bandeira de. Elementos de direito administrativo. São Paulo: Revista dos Tribunais, 1984.

MELLO, Celso Antonio Bandeira de. Prestação de serviços públicos e Administração indireta. São Paulo: Revista dos Tribunais, 1975.

MELLO, Oswaldo Aranha Bandeira de. Princípios gerais de direito administrativo. Rio de Janeiro: Forense, 1969. v. 1.

MONTEIRO, Vera; ROSILHO, André. As agências reguladoras e o controle da regulação pelo Tribunal de Contas da União. In: PEREIRA NETO, Caio Mario da Silva; PINHEIRO, Luís Felipe Valerim. Direito da infraestrutura. São Paulo. Saraiva, 2017. v. 2.

MORAND-DEVILLER, Jacqueline. Droit administratif. 12. ed. Montchrestien, 2011.

MOREIRA NETO, Diogo de Figueiredo. Uma avaliação das tendências do direito administrativo: obra em homenagem a Eduardo Garcia de Enterría, Rio de Janeiro: Renovar, 2003.

MOREIRA NETO, Diogo Figueiredo. Direito regulatório. Rio de Janeiro: Renovar, 2003.

MOREIRA NETO, Diogo Figueiredo. Mutações de direito público. Rio de Janeiro: Renovar, 2006.

MOREIRA, Egon Bockmann. Agências administrativas, contratos de serviços públicos e mutabilidade regulatória. Revista de Direito Público da Economia, Belo Horizonte, v. 25, jan./mar. 2009.

MOREIRA, Egon Bockmann. Desenvolvimento econômico, políticas públicas e pessoas privadas (passado, presente e futuro de uma perene transformação). Revista de Direito do Estado, Rio de Janeiro, v. 10, abr./jun. 2008.

MOREIRA, Egon Bockmann. Notas sobre os sistemas de controle dos atos e contratos administrativos. Fórum Administrativo, Belo Horizonte, v. 5, set. 2005. 
MOREIRA, Egon Bockmann. Os limites à competência normativa das agências reguladoras. In: ARAGÃO, Alexandre Santos de (Coord.). O poder normativo das agências reguladoras. Rio de Janeiro: Forense, 2006.

MOREIRA, Egon Bockmann. Passado, presente e futuro da regulação econômica no Brasil. Revista de Direito Público da Economia - RDPE, Belo Horizonte, v. 11, n. 44, p. 87-118, out./dez. 2013.

MOREIRA, Egon Bockmann. Processo administrativo: princípios constitucionais e a Lei 9.784/99. 3. ed. São Paulo: Malheiros, 2007.

ORGANIZAÇÃO PARA A COOPERAÇÃO E DESENVOLVIMENTO ECONÔMICO. Recomendação do Conselho sobre política regulatória e governança. Paris: OCDE, Paris, 2012. Disponível em: <http://dx.doi.org/10.1787/9789264209084-pt>. Acesso em: 5 ago. 2017.

ORTIZ, Gaspar Ariño, Lecciones de administración (y políticas públicas). Fundación Estudios de Regulación, Ilustes.

ORTIZ, Gaspar Ariño. Principios de derecho publico económico. Granada: Comares e Fundación de Estudios de Regulación, 1999.

PALMA, Juliana Bonacorsi de. Atividade normativa da Administração Pública: estudo do processo administrativo normativo. 2014. 480 p. Tese (Doutorado em Direito) Faculdade de Direito, Universidade de São Paulo, São Paulo, 2014.

PEREIRA NETO, Caio Mario da Silva; LANCIERI, Filippo Maria; ADAMI, Mateus Piva. O diálogo institucional das agências reguladoras com os Poderes Executivo, Legislativo e Judiciário: uma proposta de sistematização, In: SUNDFELD, Carlos Ari; ROSILHO, André (Orgs.). Direito da regulação e políticas públicas. São Paulo: Malheiros, 2014.

PEREZ, M. A.. As agências reguladoras no direito brasileiro: origem, natureza e função. Revista Trimestral de Direito Público, v. 23, p. 124-128, 1998.

PEREZ, M. A.. As vicissitudes da regulação econômica estatal: reflexão sobre as lições do direito norte-americano em comparação com o direito brasileiro. In: CARDOZO, José Eduardo Martins; QUEIROZ, João Eduardo Lopes; SANTOS, Márcia Walquiria Batista dos. (Orgs.). Curso de direto administrativo econômico. São Paulo: Malheiros, 2006. v. 3. p. 149-169.

PEREZ, M. A.. Controle da Administração Pública no Brasil: um breve resumo do tema. Revista Brasileira de Direito Público, v. 1, p. 69-74, 2016.

POLLITT, Christopher et al. Desempenho ou legalidade?: auditoria operacional e de gestão pública em cinco países. Tradução de Pedro Buck. Belo Horizonte: Forum, 2008.

RIBEIRO, Wladimir António. O saneamento básico como um direito social. Revista de Direito Público da Economia - RDPE, Belo Horizonte, ano 13, n. 52, p. 229-251, out./dez. 2015. 
RODRIK, D. Industrial Policy For The Twenty-First Century. Disponível em: $<$ https://www.sss.ias.edu/files/pdfs/Rodrik/Research/industrial-policy-twenty-firstcentury.pdf $>$. Acesso em: 14 jan. 2018.

RODRIK, Dani; SUBRAMANIAN, A.; TREBBI, F. Institutions Rule: The Primacy Of Institutions Over Geography And Integration In Economic Development. NBER WORKING, 2002. Disponível em:

$<$ https://www.imf.org/external/pubs/ft/wp/2002/wp02189.pdf $>$. Acesso em: 14 jan. 2018.

ROSILHO, André Janjácomo. Controle da Administração Pública pelo Tribunal de

Contas da União. 2016. Tese (Doutorado em Direito) - Faculdade de Direito, Universidade de São Paulo, São Paulo, 2016.

SALAMA, Bruno Meyerhof; BARRIONUEVO, Arthur. Dinâmica de nomeações das agências reguladoras. São Paulo: Escola de Direito FGV, 2016.

SALGADO, Lucia Helena. Agências regulatórias na experiência brasileira: um panorama do atual desenho institucional. Rio de Janeiro: Ipea, 2003. (Texto para Discussão, v. 941).

SALOMÃO FILHO, Calixto. Regulação da atividade econômica (princípios e fundamentos jurídicos). São Paulo: Malheiros, 2001.

SCHIRATO, Vitor Rhein. A deterioração do sistema regulatório brasileiro. Revista de Direito Público da Economia - RDPE, Belo Horizonte, v. 11, n. 44, out./dez. 2013.

SCHIRATO, Vitor Rhein. A experiência e as perspectivas da regulação do setor portuário no Brasil. Revista de Direito Público e Economia - RDPE, Belo Horizonte, n. 23, p. 171190, jul./set. 2008.

SCHIRATO, Vitor Rhein. As agências reguladoras independentes e alguns elementos da teoria geral do Estado. In: ARAGÃO, Alexandre Santos de; MARQUES NETO, Floriano de Azevedo (Orgs.). Direito administrativo e seus novos paradigmas. Belo Horizonte: Fórum, 2008.

SCHIRATO, Vitor Rhein. Geração de energia no Brasil: 15 anos fora do regime de serviço público. Revista de Direito Público e Economia - RDPE, Belo Horizonte, v. 8, n. 31, p. 141-168, jul./set. 2010.

SCHIRATO, Vitor Rhein. Livre iniciativa nos serviços públicos. Belo Horizonte: Fórum, 2012.

SCHIRATO, Vitor Rhein. Processo administrativo como instrumento do Estado de direito e da democracia. In: MEDAUAR; Odete; SCHIRATO, Vitor Rhein (Org.). Atuais rumos do processo administrativo.

SOUTO, Marcos Jurena Villela. Desestatização: privatizações, concessões, terceirizações e regulação. 4. ed. Rio de Janeiro: Lumen Juris, 2001. 
SPECK, Bruno Wilhelm, Inovação e rotina no Tribunal de Contas da União: o papel da instituição superior de controle financeiro no sistema político-administrativo do Brasil. São Paulo: Fundação Konrad Adenauer, 2000.

SUNDFELD, Carlos Ari (Coord.). Direito administrativo econômico. 3. tir. São Paulo: Malheiros. 2006.

SUNDFELD, Carlos Ari (Org.). Contratações públicas e seu controle. São Paulo, Malheiros, 2013.

SUNDFELD, Carlos Ari. Serviços públicos e regulação estatal: introdução às agências reguladoras. In: SUNDFELD, Carlos Ari. Direito administrativo econômico. São Paulo: Malheiros, 2000. p. 17-38.

SUNDFELD, Carlos Ari. Direito administrativo para céticos. São Paulo: Malheiros, 2012.

SUNDFELD, Carlos Ari; ARRUDA CÂMARA, Jacintho. Competências de controle dos Tribunais de Contas: possibilidades e limites. In: SUNDFELD, Carlos Ari. Contratações públicas e seu controle. São Paulo: Malheiros, 2013.

SUNDFELD, Carlos Ari; ARRUDA CÂMARA, Jacintho. Controle judicial dos atos administrativos: as questões técnicas e os limites da tutela de urgência. Interesse Público, v. 16, n. 16 , p. 23-38, 2002.

SUNDFELD, Carlos Ari; CÂMARA, Jacintho Arruda, Controle das contratações públicas pelos Tribunais de Contas. Revista de Direito Administrativo, Rio de Janeiro, v. 257, maio/ago. 2011.

SUNDFELD, Carlos Ari; CÂMARA, Jacintho Arruda. O Tribunal de Contas da União e a regulação. Fórum de Contratação e Gestão Pública - FCGP, Belo Horizonte, v. 14, n. 159, mar. 2015, p. 4. Disponível em:

$<$ http://www.bidforum.com.br/PDI0006.aspx?pdiCntd=231375>. Acesso em: 7 set. 2017.

SUNDFELD, Carlos Ari; CÂMARA, Jacintho Arruda. O Tribunal de Contas da União e a Regulação. In: FIGUEIREDO, Marcelo. (Org.). Novos rumos para o direito público: reflexões em homenagem à professora Lúcia Valle Figueiredo. Belo Horizonte: Fórum, 2012. p. 59-68.

SUNDFELD, Carlos Ari; SOUZA, Rodrigo Pagani de; PINTO, Henrique Motta. Empresas semiestatais. Revista de Direito Público da Economia - RDPE, Belo Horizonte, v. 9, n. 36, p. 75-99, out./dez. 2011.

SUNSTEIN, Cass R. As funções das normas reguladoras. Revista de Direito Público da Economia, Belo Horizonte, v. 3, jul./set. 2003.

TREBILCOCK, Michael; DAVIS, Kevin. The Relationship Between Law And Development: Optimists Versus Skeptics. The American Journal Of Comparative Law, v. 56, p. 895-946, 2008. 
TRIBUNAL DE CONTAS DA UNIÃO. Manual de auditoria operacional. 3. ed. Brasília:TCU, 2010. Disponível em: $<$ http://portal.tcu.gov.br/comunidades/fiscalizacao-econtrole/normas-de-auditoria-do-tcu/>. Acesso em: 20 ago. 2017.

VAN ARKADIE, B. The Role of Institutions in Development in the World Bank.

Proceedings of the World Bank Annual Conference on Development Economics: 1989. Washington, DC: World Bank, 1990.

VÉRAS, Rafael. As falhas na regulação brasileira. Disponível em:

$<$ http://www.direitodoestado.com.br/colunistas/Rafael-Veras/as-falhas-da-regulacaobrasileira $>$. Acesso em: 20 jun. 2016.

ZYMLER, Benjamin. Direito administrativo e controle. 3. ed. Belo Horizonte: Fórum, 2012. 


\section{APÊNDICE A - FUNDAMENTOS NORMATIVOS DA FUNÇÃO REGULATÓRIA}

Quadro 1 - Relação de dispositivos legais que atribuem à Anatel competências que compõem a função regulatória.

\begin{tabular}{|c|c|}
\hline FUNÇÃO & AGÊNCIA: ANATEL *- (Lei no 9.472/1997 - LGT) \\
\hline Normativa & $\begin{array}{l}\text { Arts. 19, IV, VIII, X, XII, XIII, XIV, XVI, XXVII }{ }^{1}, 79^{2}, 89 \text {, } \text { caput }^{3}, 97^{4}, 103^{5} \text {, } \\
109^{6}, 128^{7}, 145^{8}, 170^{9} \text {, LGT }\end{array}$ \\
\hline Fiscalizatória & $\begin{array}{l}\text { Arts. } 19 \text {, VI, IX, XI, XV, XVIII, XIX }{ }^{10}, 101^{11}, 105^{12}, 211, \S \text { único }^{13}, \text { LGT, 29, } \\
\text { caput e } \S \text { único }^{14} \text { da Lei } n^{\circ} 12.485 / 2011,4^{\circ}, I^{15} \text {, da Lei }{ }^{\circ} 9.998 / 2000\end{array}$ \\
\hline Sancionadora & Arts. 19, VI, IX, XI, XVIII, XIX ${ }^{16}, 140^{17}, 173$ a $182^{18}$, LGT \\
\hline Adjudicatória & Arts. $19, \mathrm{~V}, \mathrm{VI}, \mathrm{IX}, \mathrm{XI}^{19}, 131^{20}, 163^{21}, \mathrm{LGT}, 32, \S 7^{\mathrm{o}^{22}}$, da Lei $\mathrm{n}^{\mathrm{o}} 11.652 / 2008$ \\
\hline Recomendatória & Arts. $19, \mathrm{III}, \mathrm{XX}, \mathrm{XXX}^{23}, 35, \mathrm{I} \mathrm{II}^{24}, \mathrm{LGT}$ \\
\hline Arbitral & Art. $19, \mathrm{XVII}^{25}, \mathrm{LGT}$ \\
\hline $\begin{array}{l}\text { Celebração de } \\
\text { acordos } \\
\text { regulatórios }\end{array}$ & $\begin{array}{l}\text { Art. } 5 \text {, IV e } \$ 6^{\text {o26 }} \text {, da Lei } n^{\text {o }} 7.3471 / 1985 \text { (LACP); } \\
\text { Art. } 68^{27} \text {, da Lei } n^{\text {o }} 9.784 / 1999 \text { (LPA) }\end{array}$ \\
\hline
\end{tabular}

Fonte: Elaboração própria.

*Criação foi prevista na Constituição Federal - Art. 21, IX.

Quadro 2 - Relação de dispositivos legais que atribuem à ANTT competências que compõem a função regulatória.

\begin{tabular}{|c|c|}
\hline FUNÇÃO & AGÊNCIA: ANTT (Lei no 10.233/2001) \\
\hline Normativa & $\begin{array}{l}\text { Arts. } 14 \text {, caput, I, “j”, }{ }^{28} \text { e } 14-\mathrm{B}^{29}, 20 \text { caput, I, II }{ }^{30}, 24, \mathrm{X}^{31}, 25, \mathrm{~V}, \mathrm{VIII}^{32}, 26 \\
\mathrm{IX}^{33}, 28^{34} \text {, da Lei } \mathrm{n}^{\mathrm{o}} 10.233 / 2001\end{array}$ \\
\hline Fiscalizatória & $\begin{array}{l}\text { Arts. } 24 \text {, VI, VIII, XII, XIII, XVII }{ }^{35}, 25 \text { IV }^{36}, 26 \text { IV, VIII } \\
38^{40}, 32^{38}, 34-A^{39} \text {, da Lei } n^{\text {o }} 10.233 / 2001\end{array}$ \\
\hline Sancionadora & $\begin{array}{l}\text { Arts. } 24, \text { XVII }^{41}, 78-\mathrm{A}, \S 3^{\mathrm{o}^{42}}, 78-\mathrm{D}^{43}, 78-\mathrm{E}^{44}, 78-\mathrm{F}^{45}, 78-\mathrm{H}^{46}, 78-\mathrm{K}^{47} \text {, da Lei } \\
\mathrm{n}^{\mathrm{o}} 10.233 / 2001,6^{\mathrm{o} 48} \text {, da Lei } \mathrm{n}^{\mathrm{o}} 10.209 / 2001\end{array}$ \\
\hline Adjudicatória & $\begin{array}{l}\text { Arts. 24, V, VI, VII, IX, XIX }{ }^{49}, 25, \text { I, II, III }{ }^{50}, 26 \text { I, II, III, V, VI }{ }^{51}, 47-A^{52} \text {, } \\
47-B, \S \text { único }{ }^{53}, 48^{54}, 49^{55}, 82, \text { XIX, } 4^{0^{56}} \text {, da Lei n }{ }^{\mathrm{o}} 10.233 / 2001\end{array}$ \\
\hline Recomendatória & Art. 24, III $^{57}$, da Lei ${ }^{0} 10.233 / 2001$ \\
\hline Arbitral & Art. $25, \mathrm{~V}^{58}$, da Lei $\mathrm{n}^{\mathrm{o}} 10.233 / 2001$ \\
\hline \multirow{2}{*}{$\begin{array}{l}\text { Celebração de acordos } \\
\text { regulatórios }\end{array}$} & Art. 5, IV e $\S 6^{0^{59}}$, da Lei $n^{\mathrm{o}} 7.3471 / 1985$ (LACP); \\
\hline & Art. $68^{60}$, da Lei $n^{\circ} 9.784 / 1999$ (LPA) \\
\hline
\end{tabular}

Fonte: Elaboração própria. 
Quadro 3 - Relação de dispositivos legais que atribuem à Antaq competências que compõem a função regulatória.

\begin{tabular}{|c|c|}
\hline FUNÇÃO & AGÊNCIA: ANTAQ (Lei $n^{0}$ 10.233/2001; Lei $n^{0}$ 12.815/2013) \\
\hline Normativa & Arts. 20 caput, I, II ${ }^{61}, 27$, IV, XIV, XIX ${ }^{62}, 28^{63}$, da Lei $n^{0} 10.233 / 2001$ \\
\hline Fiscalizatória & $\begin{array}{l}\text { Arts. 20, II, 27, XII, XXI, XXII, XXVI }{ }^{64}, 32^{65}, 34-\mathrm{A}^{66}, 38^{67} \text {, da Lei } \mathrm{n}^{\mathrm{o}} \\
10.233 / 2001,16, \mathrm{III}^{68} \text {, da Lei } \mathrm{n}^{\mathrm{o}} 12.815 / 2013\end{array}$ \\
\hline Sancionadora & $\begin{array}{l}\text { Arts. } 78-\mathrm{A}, \S 2^{\mathrm{o} 69}, 78-\mathrm{D}^{70}, 78-\mathrm{E}^{71}, 78-\mathrm{F}^{72}, 78-\mathrm{H}^{73} \text {, da Lei } \mathrm{n}^{\mathrm{o}} 10.233 / 2001 \text {, } \\
8^{\mathrm{o}}, \S 3^{\mathrm{o} 74} \text {, da Lei } \mathrm{n}^{\mathrm{o}} 12.815 / 2013\end{array}$ \\
\hline Adjudicatória & $\begin{array}{l}\text { Arts. 20, I, 27, V, VII, XVI, XXV, } \S 1^{\mathrm{o}}, \mathrm{I} \mathrm{III}^{75}, \text {, da Lei } \mathrm{n}^{\mathrm{o}} 10.233 / 2001,6^{\mathrm{o}} \text {, } \\
\S 2^{\mathrm{o} 76}, 13^{77} \text {, da Lei } \mathrm{n}^{\mathrm{o}} 12.815 / 2013\end{array}$ \\
\hline Recomendatória & Art. $27, \mathrm{III}^{78}$, da Lei $\mathrm{n}^{\mathrm{o}} 10.233 / 2001$ \\
\hline Arbitral & Art. 20, II, "b"79, da Lei n ${ }^{\circ} 10.233 / 2001$ \\
\hline $\begin{array}{l}\text { Celebração de acordos } \\
\text { regulatórios }\end{array}$ & $\begin{array}{l}\text { Art. } 5 \text {, IV e } \S 6^{080} \text {, da Lei } n^{\circ} 7.3471 / 1985 \text { (LACP); } \\
\text { Art. } 68^{81} \text {, da Lei } n^{\circ} 9.784 / 1999 \text { (LPA) }\end{array}$ \\
\hline
\end{tabular}

Fonte: Elaboração própria.

Quadro 4 - Relação de dispositivos legais que atribuem à ANP competências que compõem a função regulatória.

\section{FUNÇÃO $\quad$ ANP* (Lei n* 9.478/1997; Lei n 12.351/2010)}

Normativa $\quad$ Arts. $8^{\mathrm{o}}, \mathrm{VI}, \mathrm{XXVII}{ }^{82}, 36^{83}, 53, \S 1^{\mathrm{o} 84}, 56, \S$ único $^{85}, 58, \S 1^{\mathrm{o} 86}$, da Lei no 9.478/1997

Fiscalizatória Arts. $8^{\circ}$, VII, XIII, XIX, XXIII ${ }^{87}, 8^{\circ}-A^{88}$, da Lei n ${ }^{\text {o } 9.478 / 1997, ~ 11, ~ I V, ~}$ VI $^{89}$, da Lei $n^{\circ} 12.351 / 2010,1^{\text {o90 }}$, da Lei $n^{\circ} 9.847 / 1999$

Sancionadora Arts. $8^{\circ}$, VII $^{91}, 44, V^{92}$, da Lei $n^{\circ} 9.478 / 1997$

Arts. $8^{\circ}, \mathrm{I}, \mathrm{IV}, \mathrm{V}, \mathrm{XV}, \mathrm{XVI}, \mathrm{XX}, \mathrm{XXV}, \mathrm{XXVI}^{93}, 23, \S 2^{\mathrm{o}^{94}}, 34^{95}, 51, \S$ único $^{96}$,

Adjudicatória $53, \S 2^{0^{97}}, 55^{98}, 60$, caput $^{99}, 68-\mathrm{A}^{100}$, da Lei $\mathrm{n}^{\mathrm{o}} 9.478 / 1997,11$, III, V ${ }^{101}, 24, \mathrm{I}, \mathrm{II}$, IV $^{102}, 38^{103}$, da Lei $n^{\circ} 12.351 / 2010$

Recomendatória Art. $26, \S 2^{\text {o104 }}$, da Lei no $9.478 / 1997$

Arbitral Arts. $18^{105}, 20^{106}, 43, X^{107}$, da Lei $n^{\circ} 9.478 / 1997$

Celebração de

Art. 5, IV e $\S 6^{{ }^{108}}$, da Lei n ${ }^{\text {o }} 7.3471 / 1985$ (LACP);

acordos regulatórios Art. $68^{109}$, da Lei no $9.784 / 1999$ (LPA)

Fonte: Elaboração própria.

* Criação foi prevista na Constituição Federal - art. 177, §2 , III. 
Quadro 5 - Relação de dispositivos legais que atribuem à Anac competências que compõem a função regulatória.

\begin{tabular}{|c|c|}
\hline FUNÇÃO & AGÊNCIA: ANAC (Lei no 11.182/2005) \\
\hline Normativa & Arts. $8^{\circ}, \mathrm{IV}, \mathrm{XI}, \mathrm{XXV}, \mathrm{XXIX}, \mathrm{XXX}, \mathrm{XLVI}^{110}, 11, \mathrm{~V}^{111}$ \\
\hline Fiscalizatória & Art. $8^{\circ}$, VII, X, XII, XIII, XVI, XXI, XXVIII, XXXII ${ }^{112}$ \\
\hline Sancionadora & Arts. $8^{\circ}, \mathrm{XXXV}^{113}, 11, \mathrm{VIII}^{114}$ \\
\hline Adjudicatória & $\begin{array}{l}\text { Arts. } 3^{\circ}, \mathrm{III}^{115}, 6^{\mathrm{o} 116}, 8^{\mathrm{o}}, \mathrm{V}, \mathrm{XIV}, \mathrm{XVII}, \mathrm{XXII}, \mathrm{XXIV}, \mathrm{XXXIII}, \\
\text { XLVIII }^{117}, 11, \mathrm{III}, \mathrm{IV}^{118}\end{array}$ \\
\hline Recomendatória & Arts. $8^{\mathrm{o}}, \mathrm{III}, \S 2^{\mathrm{o} 119}$ \\
\hline Arbitral & Art. $8^{\circ}, \mathrm{XX}^{120}$ \\
\hline $\begin{array}{l}\text { Celebração de acordos } \\
\text { regulatórios }\end{array}$ & $\begin{array}{l}\text { Art. } 5 \text {, IV e } \$ 6^{\mathrm{o}^{121}} \text {, da Lei } \mathrm{n}^{\mathrm{o}} 7.3471 / 1985 \text { (LACP); } \\
\text { Art. } 68^{122} \text {, da Lei } n^{\mathrm{o}} 9.784 / 1999 \text { (LPA) }\end{array}$ \\
\hline
\end{tabular}

Fonte: Elaboração própria.

Quadro 6 - Relação dedispositivos legais que atribuem à Aneel competências que compõem a função regulatória.

\begin{tabular}{|c|c|}
\hline FUNÇÃ̃ & $\begin{array}{l}\text { AGÊNCIA: ANEEL (Lei no 9.427/1996; Lei } n^{0} \text { 9.074/1995; Lei } n^{\circ} \\
\text { 12.783/2013) }\end{array}$ \\
\hline Normativa & 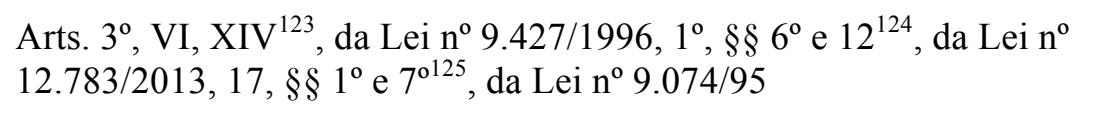 \\
\hline Fiscalizatória & $\begin{array}{l}\text { Arts. } 2^{\mathrm{o} 126}, 3^{\mathrm{o}}, \mathrm{IV}, \mathrm{IX}, \mathrm{XIII}, \mathrm{XIX}^{127} \text {, da Lei } \mathrm{n}^{\mathrm{o}} 9.427 / 1996,4^{\mathrm{o} 128}, 23 \text {, } \\
\text { parágrafo único }{ }^{129} \text {, da Lei } \mathrm{n}^{\mathrm{o}} 10.848 / 2004\end{array}$ \\
\hline Sancionadora & Arts. $3^{\circ}, X^{130}$, da Lei $n^{\circ} 9.427 / 1996,17^{131}$, da Lei n ${ }^{\circ} 12.767 / 2012$ \\
\hline Adjudicatória & $\begin{array}{l}\text { Arts. } 3^{\mathrm{o}}, \mathrm{II}, \mathrm{XV}^{132}, 20, \S 3^{\mathrm{o} 133} \text {, da Lei } \mathrm{n}^{\mathrm{o}} 9.427 / 1996 \text { e } 4^{\mathrm{o}}, \S \S 10^{\mathrm{o}}, 11, \\
13^{134}, 10^{135} \text {, da Lei } \mathrm{n}^{\mathrm{o}} 9.074 / 1995,3^{\mathrm{o} 136}, 13, \S \S 1^{\mathrm{o}} \text { e } 2^{\mathrm{o} 137} \text {, da Lei } \mathrm{n}^{\mathrm{o}} \\
12.783 / 2013,5^{\mathrm{o} 138} \text { e } 13^{139} \text {, da Lei } \mathrm{n}^{\mathrm{o}} 12.767 / 2012,2^{\mathrm{o}}, \S \S 2^{\mathrm{o}}, \mathrm{IV}, 11^{140} \mathrm{e} \\
2^{\mathrm{o}}-\mathrm{B}^{141}, \text { da Lei } \mathrm{n}^{\mathrm{o}} 10.848 / 2004,4^{\mathrm{o}}, \S 5^{\mathrm{o} 142} \text {, da Lei } \mathrm{n}^{\mathrm{o}} 10.438 / 2002\end{array}$ \\
\hline Recomendatória & Art. $2^{\circ}, \S 16^{143}$, da Lei $n^{o} 10.848 / 2004$ \\
\hline Arbitral & $\begin{array}{l}\text { Arts. } 3^{\circ}, V^{144} \text {, da Lei } n^{\circ} 9.427 / 1996,6^{\mathrm{o} 145} \text {, da Lei } n^{\mathrm{o}} 12.767 / 2012,4^{\mathrm{o}} \text {, } \\
\S \S 5^{\mathrm{o}}, \mathrm{V} \text { e } 8^{\mathrm{o}}{ }^{146} \text {, da Lei } \mathrm{n}^{\mathrm{o}} 10.438 / 2002\end{array}$ \\
\hline Celebração de acordos & Art. 5, IV e $\S 6^{0^{147}}$, da Lei no $7.3471 / 1985$ (LACP); \\
\hline regulatórios & Art. $68^{148}$, da Lei no 9.784/1999 (LPA) \\
\hline
\end{tabular}

Fonte: Elaboração própria. 
1 “Art. 19. À Agência compete adotar as medidas necessárias para o atendimento do interesse público e para o desenvolvimento das telecomunicações brasileiras, atuando com independência, imparcialidade, legalidade, impessoalidade e publicidade, e especialmente:

IV - expedir normas quanto à outorga, prestação e fruição dos serviços de telecomunicações no regime público;

VIII - administrar o espectro de radiofrequências e o uso de órbitas, expedindo as respectivas normas;

$\mathrm{X}$ - expedir normas sobre prestação de serviços de telecomunicações no regime privado;

XII - expedir normas e padrões a serem cumpridos pelas prestadoras de serviços de telecomunicações quanto aos equipamentos que utilizarem;

XIII - expedir ou reconhecer a certificação de produtos, observados os padrões e normas por ela estabelecidos;

XIV - expedir normas e padrões que assegurem a compatibilidade, a operação integrada e a interconexão entre as redes, abrangendo inclusive os equipamentos terminais;

XVI - deliberar na esfera administrativa quanto à interpretação da legislação de telecomunicações e sobre os casos omissos;

XXVII - aprovar o seu regimento interno; “

2 “Art. 79. A Agência regulará as obrigações de universalização e de continuidade atribuídas às prestadoras de serviço no regime público."

3 “Art. 89. A licitação será disciplinada pela Agência, observados os princípios constitucionais, as disposições desta Lei e, especialmente."

4 “Art. 97. Dependerão de prévia aprovação da Agência a cisão, a fusão, a transformação, a incorporação, a redução do capital da empresa ou a transferência de seu controle societário."

5 "Art. 103. Compete à Agência estabelecer a estrutura tarifária para cada modalidade de serviço."

6 “Art. 109. A Agência estabelecerá: I - os mecanismos para acompanhamento das tarifas praticadas pela concessionária, inclusive a antecedência a ser observada na comunicação de suas alterações; II - os casos de serviço gratuito, como os de emergência; III - os mecanismos para garantir a publicidade das tarifas."

7 “Art. 128. Ao impor condicionamentos administrativos ao direito de exploração das diversas modalidades de serviço no regime privado, sejam eles limites, encargos ou sujeições, a Agência observará a exigência de mínima intervenção na vida privada, assegurando que [...]."

8 “Art. 145. A implantação e o funcionamento de redes de telecomunicações destinadas a dar suporte à prestação de serviços de interesse coletivo, no regime público ou privado, observarão o disposto neste Título."

9 “Art. 170. A Agência disporá sobre os requisitos e critérios específicos para execução de serviço de telecomunicações que utilize satélite, geoestacionário ou não, independentemente de o acesso a ele ocorrer a partir do território nacional ou do exterior."

10 “Art. 19. À Agência compete adotar as medidas necessárias para o atendimento do interesse público e para o desenvolvimento das telecomunicações brasileiras, atuando com independência, imparcialidade, legalidade, impessoalidade e publicidade, e especialmente:"

11 "Art. 101. A alienação, oneração ou substituição de bens reversíveis dependerá de prévia aprovação da Agência."

12 “Art. 105. Quando da implantação de novas prestações, utilidades ou comodidades relativas ao objeto da concessão, suas tarifas serão previamente levadas à Agência, para aprovação, com os estudos correspondentes."

13 “Art. 211. A outorga dos serviços de radiodifusão sonora e de sons e imagens fica excluída da jurisdição da Agência, permanecendo no âmbito de competências do Poder Executivo, devendo a Agência elaborar e manter os respectivos planos de distribuição de canais, levando em conta, inclusive, os aspectos concernentes à evolução tecnológica. Parágrafo único. Caberá à Agência a fiscalização, quanto aos aspectos técnicos, das respectivas estações."

14 “Art. 29. A atividade de distribuição por meio do serviço de acesso condicionado é livre para empresas constituídas sob as leis brasileiras, com sede e administração no País, sendo regida pelas disposições previstas nesta Lei, na Lei no 9.472, de 16 de julho de 1997, e na regulamentação editada pela Agência Nacional de Telecomunicações - Anatel. Parágrafo único. A Anatel regulará e físcalizará a atividade de distribuição."

15 “Art. $4^{\circ}$ Compete à Anatel: I - implementar, acompanhar e fiscalizar os programas, projetos e atividades que aplicarem recursos do Fust;"

16 “Art. 19. À Agência compete adotar as medidas necessárias para o atendimento do interesse público e para o desenvolvimento das telecomunicações brasileiras, atuando com independência, imparcialidade, legalidade, impessoalidade e publicidade, e especialmente: 
VI - celebrar e gerenciar contratos de concessão e fiscalizar a prestação do serviço no regime público, aplicando sanções e realizando intervenções;

IX - editar atos de outorga e extinção do direito de uso de radiofrequência e de órbita, fiscalizando e aplicando sanções;

XI - expedir e extinguir autorização para prestação de serviço no regime privado, fiscalizando e aplicando sanções;

XVIII - reprimir infrações dos direitos dos usuários;

XIX - exercer, relativamente às telecomunicações, as competências legais em matéria de controle, prevenção e repressão das infrações da ordem econômica, ressalvadas as pertencentes ao Conselho Administrativo de Defesa Econômica - CADE;"

17 “Art. 140. Em caso de prática de infrações graves, de transferência irregular da autorização ou de descumprimento reiterado de compromissos assumidos, a Agência poderá extinguir a autorização decretando-lhe a caducidade."

18 “Art. 173. A infração desta Lei ou das demais normas aplicáveis, bem como a inobservância dos deveres decorrentes dos contratos de concessão ou dos atos de permissão, autorização de serviço ou autorização de uso de radiofrequência, sujeitará os infratores às seguintes sanções, aplicáveis pela Agência, sem prejuízo das de natureza civil e penal: I - advertência; II - multa; III - suspensão temporária; IV caducidade; V - declaração de inidoneidade.

Art. 174. Toda acusação será circunstanciada, permanecendo em sigilo até sua completa apuração.

Art. 175. Nenhuma sanção será aplicada sem a oportunidade de prévia e ampla defesa. Parágrafo único. Apenas medidas cautelares urgentes poderão ser tomadas antes da defesa.

Art. 176. Na aplicação de sanções, serão considerados a natureza e a gravidade da infração, os danos dela resultantes para o serviço e para os usuários, a vantagem auferida pelo infrator, as circunstâncias agravantes, os antecedentes do infrator e a reincidência específica. Parágrafo único. Entende-se por reincidência específica a repetição de falta de igual natureza após o recebimento de notificação anterior.

Art. 177. Nas infrações praticadas por pessoa jurídica, também serão punidos com a sanção de multa seus administradores ou controladores, quando tiverem agido de má-fé.

Art. 178. A existência de sanção anterior será considerada como agravante na aplicação de outra sanção.

Art. 179. A multa poderá ser imposta isoladamente ou em conjunto com outra sanção, não devendo ser superior a R \$ 50.000.000,00 (cinquenta milhões de reais) para cada infração cometida. $\S 1^{\circ} \mathrm{Na}$ aplicação de multa serão considerados a condição econômica do infrator e o princípio da proporcionalidade entre a gravidade da falta e a intensidade da sanção. $\S 2^{\circ}$ A imposição, a prestadora de serviço de telecomunicações, de multa decorrente de infração da ordem econômica, observará os limites previstos na legislação especifica.

Art. 180. A suspensão temporária será imposta, em relação à autorização de serviço ou de uso de radiofrequência, em caso de infração grave cujas circunstâncias não justifiquem a decretação de caducidade. Parágrafo único. O prazo da suspensão não será superior a trinta dias.

Art. 181. A caducidade importará na extinção de concessão, permissão, autorização de serviço ou autorização de uso de radiofrequência, nos casos previstos nesta Lei.

Art. 182. A declaração de inidoneidade será aplicada a quem tenha praticado atos ilícitos visando frustrar os objetivos de licitação. Parágrafo único. O prazo de vigência da declaração de inidoneidade não será superior a cinco anos."

19 “Art. 19. À Agência compete adotar as medidas necessárias para o atendimento do interesse público e para o desenvolvimento das telecomunicações brasileiras, atuando com independência, imparcialidade, legalidade, impessoalidade e publicidade, e especialmente:

V - editar atos de outorga e extinção de direito de exploração do serviço no regime público;

VI - celebrar e gerenciar contratos de concessão e fiscalizar a prestação do serviço no regime público, aplicando sanções e realizando intervenções;

IX - editar atos de outorga e extinção do direito de uso de radiofrequência e de órbita, fiscalizando e aplicando sanções;

XI - expedir e extinguir autorização para prestação de serviço no regime privado, fiscalizando e aplicando sanções."

20 “Art. 131. A exploração de serviço no regime privado dependerá de prévia autorização da Agência, que acarretará direito de uso das radiofrequências necessárias."

21 "Art. 163. O uso de radiofrequência, tendo ou não caráter de exclusividade, dependerá de prévia outorga da Agência, mediante autorização, nos termos da regulamentação."

22 “Art. 32. Fica instituída a Contribuição para o Fomento da Radiodifusão Pública, com o objetivo de propiciar meios para a melhoria dos serviços de radiodifusão pública e para a ampliação de sua penetração mediante a utilização de serviços de telecomunicações. $\S 7^{\circ}$ À Agência Nacional de 
Telecomunicações - ANATEL compete planejar, executar, acompanhar e avaliar as atividades relativas a tributação, fiscalização, arrecadação, cobrança e recolhimento da contribuição prevista neste artigo, cabendo-lhe promover as demais atividades necessárias à sua administração."

23 “Art. 19. À Agência compete adotar as medidas necessárias para o atendimento do interesse público e para o desenvolvimento das telecomunicações brasileiras, atuando com independência, imparcialidade, legalidade, impessoalidade e publicidade, e especialmente:

III - elaborar e propor ao Presidente da República, por intermédio do Ministro de Estado das Comunicações, a adoção das medidas a que se referem os incisos I a IV do artigo anterior, submetendo previamente a consulta pública as relativas aos incisos I a III;

XX - propor ao Presidente da República, por intermédio do Ministério das Comunicações, a declaração de utilidade pública, para fins de desapropriação ou instituição de servidão administrativa, dos bens necessários à implantação ou manutenção de serviço no regime público;

XXX - rever, periodicamente, os planos enumerados nos incisos II e III do artigo anterior, submetendoos, por intermédio do Ministro de Estado das Comunicações, ao Presidente da República, para aprovação."

24 “Art. 35. Cabe ao Conselho Consultivo: I - opinar, antes de seu encaminhamento ao Ministério das Comunicações, sobre o plano geral de outorgas, o plano geral de metas para universalização de serviços prestados no regime público e demais políticas governamentais de telecomunicações; II - aconselhar quanto à instituição ou eliminação da prestação de serviço no regime público."

25 “Art. 19. À Agência compete adotar as medidas necessárias para o atendimento do interesse público e para o desenvolvimento das telecomunicações brasileiras, atuando com independência, imparcialidade, legalidade, impessoalidade e publicidade, e especialmente: XVII - compor administrativamente conflitos de interesses entre prestadoras de serviço de telecomunicações."

26 “Art. 5 $5^{\circ}$ Têm legitimidade para propor a ação principal e a ação cautelar: IV - a autarquia, empresa pública, fundação ou sociedade de economia mista. $\S 6^{\circ}$ Os órgãos públicos legitimados poderão tomar dos interessados compromisso de ajustamento de sua conduta às exigências legais, mediante cominações, que terá eficácia de título executivo extrajudicial."

27 “Art. 68. As sanções, a serem aplicadas por autoridade competente, terão natureza pecuniária ou consistirão em obrigação de fazer ou de não fazer, assegurado sempre o direito de defesa."

28 “Art. 14. Ressalvado o disposto em legislação específica, o disposto no art. 13 aplica-se conforme as seguintes diretrizes: I - depende de concessão: j) transporte rodoviário coletivo regular interestadual e internacional de passageiros, que terá regulamentação específica expedida pela ANTT.”

29 “Art. 14-B. A realização de transporte rodoviário de carga própria, de cargas especiais e de produtos perigosos depende de inscrição do transportador no RNTRC em categoria específica na forma estabelecida pela ANTT."

30 “Art. 20. São objetivos das Agências Nacionais de Regulação dos Transportes Terrestre e Aquaviário: I - implementar, nas respectivas esferas de atuação, as políticas formuladas pelo Conselho Nacional de Integração de Políticas de Transporte, pelo Ministério dos Transportes e pela Secretaria de Portos da Presidência da República, nas respectivas áreas de competência, segundo os princípios e diretrizes estabelecidos nesta Lei;

II - regular ou supervisionar, em suas respectivas esferas e atribuições, as atividades de prestação de serviços e de exploração da infraestrutura de transportes, exercidas por terceiros, com vistas a: a) garantir a movimentação de pessoas e bens, em cumprimento a padrões de eficiência, segurança, conforto, regularidade, pontualidade e modicidade nos fretes e tarifas; b) harmonizar, preservado o interesse público, os objetivos dos usuários, das empresas concessionárias, permissionárias, autorizadas e arrendatárias, e de entidades delegadas, arbitrando conflitos de interesses e impedindo situações que configurem competição imperfeita ou infração da ordem econômica."

31 “Art. 24. Cabe à ANTT, em sua esfera de atuação, como atribuições gerais: X - adotar procedimentos para a incorporação ou desincorporação de bens, no âmbito dos arrendamentos contratados."

32 “Art. 25. Cabe à ANTT, como atribuições específicas pertinentes ao Transporte Ferroviário: V - regular e coordenar a atuação dos concessionários, assegurando neutralidade com relação aos interesses dos usuários, orientando e disciplinando o tráfego mútuo e o direito de passagem de trens de passageiros e cargas e arbitrando as questões não resolvidas pelas partes; VIII - regular os procedimentos e as condições para cessão a terceiros de capacidade de tráfego disponível na infraestrutura ferroviária explorada por concessionários."

33 “Art. 26. Cabe à ANTT, como atribuições específicas pertinentes ao Transporte Rodoviário: IX - dispor sobre os requisitos mínimos a serem observados pelos terminais rodoviários de passageiros e pontos de parada dos veículos para a prestação dos serviços disciplinados por esta Lei." 
34 “Art. 28. A ANTT e a ANTAQ, em suas respectivas esferas de atuação, adotarão as normas e os procedimentos estabelecidos nesta Lei para as diferentes formas de outorga previstos nos arts. 13 e 14 , visando a que:"

35 “Art. 24. Cabe à ANTT, em sua esfera de atuação, como atribuições gerais: VI - reunir, sob sua administração, os instrumentos de outorga para exploração de infraestrutura e prestação de serviços de transporte terrestre já celebrados antes da vigência desta Lei, resguardando os direitos das partes e o equilíbrio econômico-financeiro dos respectivos contratos; VIII - fiscalizar a prestação dos serviços e a manutenção dos bens arrendados, cumprindo e fazendo cumprir as cláusulas e condições avençadas nas outorgas e aplicando penalidades pelo seu descumprimento; XII - habilitar o Operador do Transporte Multimodal, em articulação com as demais agências reguladoras de transportes; XIII - promover levantamentos e organizar cadastro relativos ao sistema de dutovias do Brasil e às empresas proprietárias de equipamentos e instalações de transporte dutoviário; XVII - exercer, diretamente ou mediante convênio, as competências expressas no inciso VIII do art. 21 da Lei no 9.503, de 23 de setembro de 1997 - Código de Trânsito Brasileiro, nas rodovias federais por ela administradas."

36 “Art. 25. Cabe à ANTT, como atribuições específicas pertinentes ao Transporte Ferroviário: IV fiscalizar diretamente, com o apoio de suas unidades regionais, ou por meio de convênios de cooperação, o cumprimento das cláusulas contratuais de prestação de serviços ferroviários e de manutenção e reposição dos ativos arrendados."

37 “Art. 26. Cabe à ANTT, como atribuições específicas pertinentes ao Transporte Rodoviário: IV promover estudos e levantamentos relativos à frota de caminhões, empresas constituídas e operadores autônomos, bem como organizar e manter um registro nacional de transportadores rodoviários de cargas; VII - fiscalizar diretamente, com o apoio de suas unidades regionais, ou por meio de convênios de cooperação, o cumprimento das condições de outorga de autorização e das cláusulas contratuais de permissão para prestação de serviços ou de concessão para exploração da infraestrutura."

38 "Art. 32. As Agências acompanharão as atividades dos operadores estrangeiros que atuam no transporte internacional com o Brasil, visando a identificar práticas operacionais, legislações e procedimentos, adotados em outros países, que restrinjam ou conflitem com regulamentos e acordos internacionais firmados pelo Brasil."

39 “Art. 34-A. As concessões e as suas prorrogações, a serem outorgadas pela ANTT e pela Antaq para a exploração de infraestrutura, precedidas ou não de obra pública, ou para prestação de serviços de transporte ferroviário associado à exploração de infraestrutura, poderão ter caráter de exclusividade quanto a seu objeto, nos termos do edital e do contrato, devendo as novas concessões serem precedidas de licitação disciplinada em regulamento próprio, aprovado pela Diretoria da Agência."

40 “Art. 38. As permissões a serem outorgadas pela ANTT para o transporte rodoviário interestadual semiurbano e para o transporte ferroviário e pela ANTAQ aplicar-se-ão à prestação regular de serviços de transporte de passageiros que independam da exploração da infraestrutura utilizada e não tenham caráter de exclusividade ao longo das rotas percorridas, devendo também ser precedidas de licitação regida por regulamento próprio, aprovado pela diretoria da Agência e pelo respectivo edital."

41 “Art. 24. Cabe à ANTT, em sua esfera de atuação, como atribuições gerais: XVII - exercer, diretamente ou mediante convênio, as competências expressas no inciso VIII do art. 21 da Lei no 9.503, de 23 de setembro de 1997 - Código de Trânsito Brasileiro, nas rodovias federais por ela administradas."

42 “Art. 78-A. A infração a esta Lei e o descumprimento dos deveres estabelecidos no contrato de concessão, no termo de permissão e na autorização sujeitará o responsável às seguintes sanções, aplicáveis pela ANTT e pela ANTAQ, sem prejuízo das de natureza civil e penal: I - advertência; II multa; III - suspensão; IV - cassação; V - declaração de inidoneidade; VI - perdimento do veículo. $\S 3^{\circ}$ Caberá exclusivamente à ANTT a aplicação da sanção referida no inciso VI do caput."

43 “Art. 78-D. Na aplicação de sanções serão consideradas a natureza e a gravidade da infração, os danos dela resultantes para o serviço e para os usuários, a vantagem auferida pelo infrator, as circunstâncias agravantes e atenuantes, os antecedentes do infrator e a reincidência genérica ou específica."

44 “Art. 78-E. Nas infrações praticadas por pessoa jurídica, também serão punidos com sanção de multa seus administradores ou controladores, quando tiverem agido com dolo ou culpa."

45 "Art. 78-F. A multa poderá ser imposta isoladamente ou em conjunto com outra sanção e não deve ser superior a R\$10.000.000,00 (dez milhões de reais)."

46 “Art. 78-H. Na ocorrência de infração grave, apurada em processo regular instaurado na forma do regulamento, a ANTT e a ANTAQ poderão cassar a autorização."

47 “Art. 78-K. O perdimento do veículo aplica-se quando houver reincidência no seu uso, dentro do período de 1 (um) ano, no transporte terrestre coletivo interestadual ou internacional de passageiros remunerado, realizado por pessoa física ou jurídica que não possua ato de outorga expedido pela ANTT.” 
48 “Art. $6^{\circ}$ Compete à ANTT a adoção das medidas indispensáveis à implantação do Vale-Pedágio obrigatório, a regulamentação, a coordenação, a delegação e a fiscalização, o processamento e a aplicação das penalidades por infrações a esta Lei."

49 “Art. 24. Cabe à ANTT, em sua esfera de atuação, como atribuições gerais: V - editar atos de outorga e de extinção de direito de exploração de infraestrutura e de prestação de serviços de transporte terrestre, celebrando e gerindo os respectivos contratos e demais instrumentos administrativos: VI - reunir, sob sua administração, os instrumentos de outorga para exploração de infraestrutura e prestação de serviços de transporte terrestre já celebrados antes da vigência desta Lei, resguardando os direitos das partes e o equilíbrio econômico-financeiro dos respectivos contratos; VII - proceder à revisão e ao reajuste de tarifas dos serviços prestados, segundo as disposições contratuais, após prévia comunicação ao Ministério da Fazenda; IX - autorizar projetos e investimentos no âmbito das outorgas estabelecidas; XIX - declarar a utilidade pública para fins de desapropriação ou de servidão administrativa de bens e propriedades necessários à execução de obras no âmbito das outorgas estabelecidas."

50 “Art. 25. Cabe à ANTT, como atribuições específicas pertinentes ao Transporte Ferroviário: I - publicar os editais, julgar as licitações e celebrar os contratos de concessão para prestação de serviços de transporte ferroviário, permitindo-se sua vinculação com contratos de arrendamento de ativos operacionais; II - administrar os contratos de concessão e arrendamento de ferrovias celebrados até a vigência desta Lei, em consonância com o inciso VI do art. 24; III - publicar editais, julgar as licitações e celebrar contratos de concessão para construção e exploração de novas ferrovias, com cláusulas de reversão à União dos ativos operacionais edificados e instalados."

51 “Art. 26. Cabe à ANTT, como atribuições específicas pertinentes ao Transporte Rodoviário: I - publicar os editais, julgar as licitações e celebrar os contratos de permissão para prestação de serviços regulares de transporte rodoviário interestadual semiurbano de passageiros; II - autorizar o transporte de passageiros, realizado por empresas de turismo, com a finalidade de turismo; III - autorizar o transporte de passageiros, sob regime de fretamento; V - habilitar o transportador internacional de carga; VI - publicar os editais, julgar as licitações e celebrar os contratos de concessão de rodovias federais a serem exploradas e administradas por terceiros."

52 “Art. 47-A. Em função das características de cada mercado, a ANTT poderá estabelecer condições específicas para a outorga de autorização para o serviço regular de transporte rodoviário interestadual e internacional de passageiros."

53 “Art. 47-B. Não haverá limite para o número de autorizações para o serviço regular de transporte rodoviário interestadual e internacional de passageiros, salvo no caso de inviabilidade operacional. Parágrafo único. Na hipótese do caput, a ANTT poderá realizar processo seletivo público para outorga da autorização, observados os princípios da legalidade, impessoalidade, moralidade, publicidade e eficiência, na forma do regulamento."

54 “Art. 48. Em caso de perda das condições indispensáveis ao cumprimento do objeto da autorização, ou de sua transferência irregular, a Agência extingui-la-á mediante cassação.”

55 “Art. 49. É facultado à Agência autorizar a prestação de serviços de transporte sujeitos a outras formas de outorga, em caráter especial e de emergência."

56 “Art. 82. São atribuições do DNIT, em sua esfera de atuação: XIX - propor ao Ministério dos Transportes, em conjunto com a ANTT, a destinação dos ativos operacionais ao término dos contratos de arrendamento. $\S 4^{\circ} \mathrm{O}$ DNIT e a ANTT celebrarão, obrigatoriamente, instrumento para execução das atribuições de que trata o inciso XVII do caput deste artigo, cabendo à ANTT a responsabilidade concorrente pela execução do controle patrimonial e contábil dos bens operacionais recebidos pelo DNIT vinculados aos contratos de arrendamento referidos nos incisos II e IV do caput do art. 25 desta Lei."

57 “Art. 24. Cabe à ANTT, em sua esfera de atuação, como atribuições gerais: III - propor ao Ministério dos Transportes, nos casos de concessão e permissão, os planos de outorgas, instruídos por estudos específicos de viabilidade técnica e econômica, para exploração da infraestrutura e a prestação de serviços de transporte terrestre."

58 “Art. 25. Cabe à ANTT, como atribuições específicas pertinentes ao Transporte Ferroviário: V - regular e coordenar a atuação dos concessionários, assegurando neutralidade com relação aos interesses dos usuários, orientando e disciplinando o tráfego mútuo e o direito de passagem de trens de passageiros e cargas e arbitrando as questões não resolvidas pelas partes."

59 “Art. 5 $5^{\circ}$ Têm legitimidade para propor a ação principal e a ação cautelar: IV - a autarquia, empresa pública, fundação ou sociedade de economia mista. $\S 6^{\circ}$ Os órgãos públicos legitimados poderão tomar dos interessados compromisso de ajustamento de sua conduta às exigências legais, mediante cominações, que terá eficácia de título executivo extrajudicial."

60 “Art. 68. As sanções, a serem aplicadas por autoridade competente, terão natureza pecuniária ou consistirão em obrigação de fazer ou de não fazer, assegurado sempre o direito de defesa." 
61 “Art. 20. São objetivos das Agências Nacionais de Regulação dos Transportes Terrestre e Aquaviário: I implementar, nas respectivas esferas de atuação, as políticas formuladas pelo Conselho Nacional de Integração de Políticas de Transporte, pelo Ministério dos Transportes e pela Secretaria de Portos da Presidência da República, nas respectivas áreas de competência, segundo os princípios e diretrizes estabelecidos nesta Lei; II - regular ou supervisionar, em suas respectivas esferas e atribuições, as atividades de prestação de serviços e de exploração da infraestrutura de transportes, exercidas por terceiros, com vistas a: a) garantir a movimentação de pessoas e bens, em cumprimento a padrões de eficiência, segurança, conforto, regularidade, pontualidade e modicidade nos fretes e tarifas; b) harmonizar, preservado o interesse público, os objetivos dos usuários, das empresas concessionárias, permissionárias, autorizadas e arrendatárias, e de entidades delegadas, arbitrando conflitos de interesses e impedindo situações que configurem competição imperfeita ou infração da ordem econômica."

62 “Art. 27. Cabe à ANTAQ, em sua esfera de atuação: IV - elaborar e editar normas e regulamentos relativos à prestação de serviços de transporte e à exploração da infraestrutura aquaviária e portuária, garantindo isonomia no seu acesso e uso, assegurando os direitos dos usuários e fomentando a competição entre os operadores; XIV - estabelecer normas e padrões a serem observados pelas administrações portuárias, concessionários, arrendatários, autorizatários e operadores portuários, nos termos da Lei na qual foi convertida a Medida Provisória $n^{0}$ 595, de 6 de dezembro de 2012; XIX estabelecer padrões e normas técnicas relativos às operações de transporte aquaviário de cargas especiais e perigosas."

63 “Art. 28. A ANTT e a ANTAQ, em suas respectivas esferas de atuação, adotarão as normas e os procedimentos estabelecidos nesta Lei para as diferentes formas de outorga previstas nos arts. 13 e 14 , visando a que:"

64 “Art. 27. Cabe à ANTAQ, em sua esfera de atuação: XXII - fiscalizar a execução dos contratos de adesão das autorizações de instalação portuária de que trata o art. 80 da Lei na qual foi convertida a Medida Provisória $n^{\circ}$ 595, de 6 de dezembro de 2012; XXI - fiscalizar o funcionamento e a prestação de serviços das empresas de navegação de longo curso, de cabotagem, de apoio marítimo, de apoio portuário, fluvial e lacustre; XXII - fiscalizar a execução dos contratos de adesão das autorizações de instalação portuária de que trata o art. 80 da Lei na qual foi convertida a Medida Provisória $n^{\circ}$ 595, de 6 de dezembro de 2012; XXVI - fiscalizar a execução dos contratos de concessão de porto organizado e de arrendamento de instalação portuária, em conformidade com o disposto na Lei na qual foi convertida a Medida Provisória n 595 , de 6 de dezembro de 2012."

65 “Art. 32. As Agências acompanharão as atividades dos operadores estrangeiros que atuam no transporte internacional com o Brasil, visando a identificar práticas operacionais, legislações e procedimentos, adotados em outros países, que restrinjam ou conflitem com regulamentos e acordos internacionais firmados pelo Brasil."

66 “Art. 34-A. As concessões e as suas prorrogações, a serem outorgadas pela ANTT e pela Antaq para a exploração de infraestrutura, precedidas ou não de obra pública, ou para prestação de serviços de transporte ferroviário associado à exploração de infraestrutura, poderão ter caráter de exclusividade quanto a seu objeto, nos termos do edital e do contrato, devendo as novas concessões serem precedidas de licitação disciplinada em regulamento próprio, aprovado pela Diretoria da Agência."

67 "Art. 38. As permissões a serem outorgadas pela ANTT para o transporte rodoviário interestadual semiurbano e para o transporte ferroviário e pela ANTAQ aplicar-se-ão à prestação regular de serviços de transporte de passageiros que independam da exploração da infraestrutura utilizada e não tenham caráter de exclusividade ao longo das rotas percorridas, devendo também ser precedidas de licitação regida por regulamento próprio, aprovado pela diretoria da Agência e pelo respectivo edital.

68 "Art. 16. Ao poder concedente compete: III - celebrar os contratos de concessão e arrendamento e expedir as autorizações de instalação portuária, devendo a Antaq fiscalizá-los em conformidade com o disposto na Lei no 10.233, de 5 de junho de 2001."

69 "Art. 78-A. A infração a esta Lei e o descumprimento dos deveres estabelecidos no contrato de concessão, no termo de permissão e na autorização sujeitará o responsável às seguintes sanções, aplicáveis pela ANTT e pela ANTAQ, sem prejuízo das de natureza civil e penal: I - advertência; II multa; III - suspensão; IV - cassação; V - declaração de inidoneidade; VI - perdimento do veículo. $\S 2^{\circ} \mathrm{A}$ aplicação da sanção prevista no inciso IV do caput, quando se tratar de concessão de porto organizado ou arrendamento e autorização de instalação portuária, caberá ao poder concedente, mediante proposta da Antaq."

70 "Art. 78-D. Na aplicação de sanções serão consideradas a natureza e a gravidade da infração, os danos dela resultantes para o serviço e para os usuários, a vantagem auferida pelo infrator, as circunstâncias agravantes e atenuantes, os antecedentes do infrator e a reincidência genérica ou específica." 
71 “Art. 78-E. Nas infrações praticadas por pessoa jurídica, também serão punidos com sanção de multa seus administradores ou controladores, quando tiverem agido com dolo ou culpa."

72 “Art. 78-F. A multa poderá ser imposta isoladamente ou em conjunto com outra sanção e não deve ser superior a R\$10.000.000,00 (dez milhões de reais)."

73 “Art. 78-H. Na ocorrência de infração grave, apurada em processo regular instaurado na forma do regulamento, a ANTT e a ANTAQ poderão cassar a autorização."

74 "§ $3^{\circ}$ A Antaq adotará as medidas para assegurar o cumprimento dos cronogramas de investimento previstos nas autorizações e poderá exigir garantias ou aplicar sanções, inclusive a cassação da autorização."

75 “Art. 27. Cabe à ANTAQ, em sua esfera de atuação: V - celebrar atos de outorga de permissão ou autorização de prestação de serviços de transporte pelas empresas de navegação fluvial, lacustre, de travessia, de apoio marítimo, de apoio portuário, de cabotagem e de longo curso, observado o disposto nos art. 13 e 14, gerindo os respectivos contratos e demais instrumentos administrativos; VII - promover as revisões e os reajustes das tarifas portuárias, assegurada a comunicação prévia, com antecedência mínima de 15 (quinze) dias úteis, ao poder concedente e ao Ministério da Fazenda; XVI - cumprir e fazer cumprir as cláusulas e condições dos contratos de concessão de porto organizado ou dos contratos de arrendamento de instalações portuárias quanto à manutenção e reposição dos bens e equipamentos reversíveis à União de que trata o inciso VIII do caput do art. 5o da Lei na qual foi convertida a Medida Provisória $\mathrm{n}^{\mathrm{o}}$ 595, de 6 de dezembro de 2012; XXV - celebrar atos de outorga de concessão para a exploração da infraestrutura aquaviária, gerindo e fiscalizando os respectivos contratos e demais instrumentos administrativos. $\S 1^{\circ}$ No exercício de suas atribuições a ANTAQ poderá: I - firmar convênios de cooperação técnica e administrativa com órgãos e entidades da Administração Pública Federal, dos Estados, do Distrito Federal e dos Municípios, tendo em vista a descentralização e a fiscalização eficiente das outorgas; III - firmar convênios de cooperação técnica com entidades e organismos internacionais."

76 “Art. $6^{\circ}$ Nas licitações dos contratos de concessão e arrendamento, serão considerados como critérios para julgamento, de forma isolada ou combinada, a maior capacidade de movimentação, a menor tarifa ou o menor tempo de movimentação de carga, e outros estabelecidos no edital, na forma do regulamento. $\S 2^{\circ}$ Compete à Antaq, com base nas diretrizes do poder concedente, realizar os procedimentos licitatórios de que trata este artigo."

77 “Art. 13. A Antaq poderá disciplinar as condições de acesso, por qualquer interessado, em caráter excepcional, às instalações portuárias autorizadas, assegurada remuneração adequada ao titular da autorização."

78 “Art. 27. Cabe à ANTAQ, em sua esfera de atuação: II - promover estudos aplicados às definições de tarifas, preços e fretes, em confronto com os custos e os benefícios econômicos transferidos aos usuários pelos investimentos realizados;"

79 “Art. 20. São objetivos das Agências Nacionais de Regulação dos Transportes Terrestre e Aquaviário: II - regular ou supervisionar, em suas respectivas esferas e atribuições, as atividades de prestação de serviços e de exploração da infraestrutura de transportes, exercidas por terceiros, com vistas a: b) harmonizar, preservado o interesse público, os objetivos dos usuários, das empresas concessionárias, permissionárias, autorizadas e arrendatárias, e de entidades delegadas, arbitrando conflitos de interesses e impedindo situações que configurem competição imperfeita ou infração da ordem econômica."

80 “Art. $5^{\circ}$ Têm legitimidade para propor a ação principal e a ação cautelar: IV - a autarquia, empresa pública, fundação ou sociedade de economia mista. $\S 6^{\circ}$ Os órgãos públicos legitimados poderão tomar dos interessados compromisso de ajustamento de sua conduta às exigências legais, mediante cominações, que terá eficácia de título executivo extrajudicial."

81 “Art. 68. As sanções, a serem aplicadas por autoridade competente, terão natureza pecuniária ou consistirão em obrigação de fazer ou de não fazer, assegurado sempre o direito de defesa."

82 “Art. $8^{\circ}$ A ANP terá como finalidade promover a regulação, a contratação e a fiscalização das atividades econômicas integrantes da indústria do petróleo, do gás natural e dos biocombustíveis, cabendo-lhe: VI estabelecer critérios para o cálculo de tarifas de transporte dutoviário e arbitrar seus valores, nos casos e da forma previstos nesta Lei; XXVII - estabelecer critérios para a aferição da capacidade dos gasodutos de transporte e de transferência."

83 “Art. 36. A licitação para outorga dos contratos de concessão referidos no art. 23 obedecerá ao disposto nesta Lei, na regulamentação a ser expedida pela ANP e no respectivo edital."

84 “Art. 53. Qualquer empresa ou consórcio de empresas que atenda ao disposto no art. 5o desta Lei poderá submeter à ANP proposta, acompanhada do respectivo projeto, para a construção e operação de refinarias e de unidades de processamento, de liquefação, de regaseificação e de estocagem de gás natural, bem como para a ampliação de sua capacidade. $\S 1^{\circ}$ A ANP estabelecerá os requisitos técnicos, econômicos e 
jurídicos a serem atendidos pelos proponentes e as exigências de projeto quanto à proteção ambiental e à segurança industrial e das populações."

85 “Art. 56. Observadas as disposições das leis pertinentes, qualquer empresa ou consórcio de empresas que atender ao disposto no art. $5^{\circ}$ poderá receber autorização da ANP para construir instalações e efetuar qualquer modalidade de transporte de petróleo, seus derivados e gás natural, seja para suprimento interno ou para importação e exportação. Parágrafo único. A ANP baixará normas sobre a habilitação dos interessados e as condições para a autorização e para transferência de sua titularidade, observado o atendimento aos requisitos de proteção ambiental e segurança de tráfego."

86 “Art. 58. Será facultado a qualquer interessado o uso dos dutos de transporte e dos terminais marítimos existentes ou a serem construídos, com exceção dos terminais de Gás Natural Liquefeito - GNL, mediante remuneração adequada ao titular das instalações ou da capacidade de movimentação de gás natural, nos termos da lei e da regulamentação aplicável. $\S 1^{\circ}$ A ANP fixará o valor e a forma de pagamento da remuneração adequada com base em critérios previamente estabelecidos, caso não haja acordo entre as partes, cabendo-lhe também verificar se o valor acordado é compatível com o mercado."

87 “Art. $8^{\circ}$ A ANP terá como finalidade promover a regulação, a contratação e a físcalização das atividades econômicas integrantes da indústria do petróleo, do gás natural e dos biocombustíveis, cabendo-lhe: VII fiscalizar diretamente e de forma concorrente nos termos da Lei no 8.078, de 11 de setembro de 1990, ou mediante convênios com órgãos dos Estados e do Distrito Federal as atividades integrantes da indústria do petróleo, do gás natural e dos biocombustíveis, bem como aplicar as sanções administrativas e pecuniárias previstas em lei, regulamento ou contrato; XIII - fiscalizar o adequado funcionamento do Sistema Nacional de Estoques de Combustíveis e o cumprimento do Plano Anual de Estoques Estratégicos de Combustíveis, de que trata o art. $4^{\text {o }}$ da Lei $\mathrm{n}^{\circ}$ 8.176, de 8 de fevereiro de 1991; XIX regular e fiscalizar o acesso à capacidade dos gasodutos; XXIII - regular e fiscalizar o exercício da atividade de estocagem de gás natural, inclusive no que se refere ao direito de acesso de terceiros às instalações concedidas."

88 “Art. $8^{\circ}$-A. Caberá à ANP supervisionar a movimentação de gás natural na rede de transporte e coordenála em situações caracterizadas como de contingência."

89 “Art. 11. Caberá à ANP, entre outras competências definidas em lei: IV - fazer cumprir as melhores práticas da indústria do petróleo; VI - regular e fiscalizar as atividades realizadas sob o regime de partilha de produção, nos termos do inciso VII do art. 80 da Lei no 9.478, de 6 de agosto de 1997."

90 “Art. $1^{\circ} \mathrm{A}$ físcalização das atividades relativas às indústrias do petróleo e dos biocombustíveis e ao abastecimento nacional de combustíveis, bem como do adequado funcionamento do Sistema Nacional de Estoques de Combustíveis e do cumprimento do Plano Anual de Estoques Estratégicos de Combustíveis, de que trata a Lei no 9.478, de 6 de agosto de 1997, será realizada pela Agência Nacional do Petróleo, Gás Natural e Biocombustíveis (ANP) ou, mediante convênios por ela celebrados, por órgãos da administração pública direta e indireta da União, dos Estados, do Distrito Federal e dos Municípios.”

91 “Art. $8^{\circ}$ A ANP terá como finalidade promover a regulação, a contratação e a fiscalização das atividades econômicas integrantes da indústria do petróleo, do gás natural e dos biocombustíveis, cabendo-lhe: VII fiscalizar diretamente e de forma concorrente nos termos da Lei no 8.078, de 11 de setembro de 1990, ou mediante convênios com órgãos dos Estados e do Distrito Federal as atividades integrantes da indústria do petróleo, do gás natural e dos biocombustíveis, bem como aplicar as sanções administrativas e pecuniárias previstas em lei, regulamento ou contrato."

92 “Art. 44. O contrato estabelecerá que o concessionário estará obrigado a: V - responsabilizar-se civilmente pelos atos de seus prepostos e indenizar todos e quaisquer danos decorrentes das atividades de exploração, desenvolvimento e produção contratadas, devendo ressarcir à ANP ou à União os ônus que venham a suportar em consequência de eventuais demandas motivadas por atos de responsabilidade do concessionário;"

93 “Art. 80 A ANP terá como finalidade promover a regulação, a contratação e a fiscalização das atividades econômicas integrantes da indústria do petróleo, do gás natural e dos biocombustíveis, cabendo-lhe: I implementar, em sua esfera de atribuições, a política nacional de petróleo, gás natural e biocombustíveis, contida na política energética nacional, nos termos do Capítulo I desta Lei, com ênfase na garantia do suprimento de derivados de petróleo, gás natural e seus derivados, e de biocombustíveis, em todo o território nacional, e na proteção dos interesses dos consumidores quanto a preço, qualidade e oferta dos produtos; IV - elaborar os editais e promover as licitações para a concessão de exploração, desenvolvimento e produção, celebrando os contratos delas decorrentes e fiscalizando a sua execução; V autorizar a prática das atividades de refinação, liquefação, regaseificação, carregamento, processamento, tratamento, transporte, estocagem e acondicionamento; XV - regular e autorizar as atividades relacionadas com o abastecimento nacional de combustíveis, fiscalizando-as diretamente ou mediante convênios com outros órgãos da União, Estados, Distrito Federal ou Municípios; XVI - regular e 
autorizar as atividades relacionadas à produção, à importação, à exportação, à armazenagem, à estocagem, ao transporte, à transferência, à distribuição, à revenda e à comercialização de biocombustíveis, assim como avaliação de conformidade e certificação de sua qualidade, fiscalizando-as diretamente ou mediante convênios com outros órgãos da União, Estados, Distrito Federal ou Municípios; $\mathrm{XX}$ - promover, direta ou indiretamente, as chamadas públicas para a contratação de capacidade de transporte de gás natural, conforme as diretrizes do Ministério de Minas e Energia; XXV - celebrar, mediante delegação do Ministério de Minas e Energia, os contratos de concessão para a exploração das atividades de transporte e estocagem de gás natural sujeitas ao regime de concessão; XXVI - autorizar a prática da atividade de comercialização de gás natural, dentro da esfera de competência da União."

94 “Art. 23. As atividades de exploração, desenvolvimento e produção de petróleo e de gás natural serão exercidas mediante contratos de concessão, precedidos de licitação, na forma estabelecida nesta Lei, ou sob o regime de partilha de produção nas áreas do pré-sal e nas áreas estratégicas, conforme legislação específica. $\S 2^{\circ}$ A ANP poderá outorgar diretamente ao titular de direito de lavra ou de autorização de pesquisa de depósito de carvão mineral concessão para o aproveitamento do gás metano que ocorra associado a esse depósito, dispensada a licitação prevista no caput deste artigo."

95 “Art. 34. Cumprido o disposto no art. 31 e dentro do prazo de um ano a partir da data de publicação desta Lei, a ANP celebrará com a PETROBRÁS, dispensada a licitação prevista no art. 23, contratos de concessão dos blocos que atendam às condições estipuladas nos arts. 32 e 33, definindo-se, em cada um desses contratos, as participações devidas, nos termos estabelecidos na Seção VI."

96 “Art. 51. O edital e o contrato disporão sobre o pagamento pela ocupação ou retenção de área, a ser feito anualmente, fixado por quilômetro quadrado ou fração da superfície do bloco, na forma da regulamentação por decreto do Presidente da República. Parágrafo único. O valor do pagamento pela ocupação ou retenção de área será aumentado em percentual a ser estabelecido pela ANP, sempre que houver prorrogação do prazo de exploração."

97 “Art. 53. Qualquer empresa ou consórcio de empresas que atenda ao disposto no art. 5o desta Lei poderá submeter à ANP proposta, acompanhada do respectivo projeto, para a construção e operação de refinarias e de unidades de processamento, de liquefação, de regaseificação e de estocagem de gás natural, bem como para a ampliação de sua capacidade. $\S 2^{\circ}$ Atendido o disposto no parágrafo anterior, a ANP outorgará a autorização a que se refere o inciso V do art. $8^{\circ}$, definindo seu objeto e sua titularidade."

98 “Art. 55. No prazo de cento e oitenta dias, a partir da publicação desta Lei, a ANP expedirá as autorizações relativas às refinarias e unidades de processamento de gás natural existentes, ratificando sua titularidade e seus direitos."

99 “Art. 60. Qualquer empresa ou consórcio de empresas que atender ao disposto no art. $5^{\circ}$ poderá receber autorização da ANP para exercer a atividade de importação e exportação de petróleo e seus derivados, de gás natural e condensado."

100 “Art. 68-A. Qualquer empresa ou consórcio de empresas constituídas sob as leis brasileiras com sede e administração no País poderá obter autorização da ANP para exercer as atividades econômicas da indústria de biocombustíveis."

101 “Art. 11. Caberá à ANP, entre outras competências definidas em lei: II - promover as licitações previstas no inciso II do art. 80 desta Lei; V - analisar e aprovar, de acordo com o disposto no inciso IV deste artigo, os planos de exploração, de avaliação e de desenvolvimento da produção, bem como os programas anuais de trabalho e de produção relativos aos contratos de partilha de produção."

102 “Art. 24. Caberá ao comitê operacional: I - definir os planos de exploração, a serem submetidos à análise e à aprovação da ANP; II - definir o plano de avaliação de descoberta de jazida de petróleo e de gás natural a ser submetido à análise e à aprovação da ANP; IV - definir os programas anuais de trabalho e de produção, a serem submetidos à análise e à aprovação da ANP."

103 “Art. 38. A ANP poderá contratar diretamente a Petrobras para realizar as atividades de avaliação das jazidas previstas nos arts. 36 e 37."

104 “Art. 26. A concessão implica, para o concessionário, a obrigação de explorar, por sua conta e risco e, em caso de êxito, produzir petróleo ou gás natural em determinado bloco, conferindo-lhe a propriedade desses bens, após extraídos, com os encargos relativos ao pagamento dos tributos incidentes e das participações legais ou contratuais correspondentes. $\S 2^{\circ}$ A ANP emitirá seu parecer sobre os planos e projetos referidos no parágrafo anterior no prazo máximo de cento e oitenta dias."

105 "Art. 18. As sessões deliberativas da Diretoria da ANP que se destinem a resolver pendências entre agentes econômicos e entre esses e consumidores e usuários de bens e serviços da indústria de petróleo, de gás natural ou de biocombustíveis serão públicas, permitida a sua gravação por meios eletrônicos e assegurado aos interessados o direito de delas obter transcrições." 
106 “Art. 20. O regimento interno da ANP disporá sobre os procedimentos a serem adotados para a solução de conflitos entre agentes econômicos, e entre estes e usuários e consumidores, com ênfase na conciliação e no arbitramento."

107 "Art. 43. O contrato de concessão deverá refletir fielmente as condições do edital e da proposta vencedora e terá como cláusulas essenciais: $\mathrm{X}$ - as regras sobre solução de controvérsias, relacionadas com o contrato e sua execução, inclusive a conciliação e a arbitragem internacional."

108 “Art. 5 $5^{\circ}$ Têm legitimidade para propor a ação principal e a ação cautelar: IV - a autarquia, empresa pública, fundação ou sociedade de economia mista. $\S 6^{\circ}$ Os órgãos públicos legitimados poderão tomar dos interessados compromisso de ajustamento de sua conduta às exigências legais, mediante cominações, que terá eficácia de título executivo extrajudicial."

109 “Art. 68. As sanções, a serem aplicadas por autoridade competente, terão natureza pecuniária ou consistirão em obrigação de fazer ou de não fazer, assegurado sempre o direito de defesa."

110 “Art. $8^{\circ}$ Cabe à ANAC adotar as medidas necessárias para o atendimento do interesse público e para o desenvolvimento e fomento da aviação civil, da infraestrutura aeronáutica e aeroportuária do País, atuando com independência, legalidade, impessoalidade e publicidade, competindo-lhe: IV - realizar estudos, estabelecer normas, promover a implementação das normas e recomendações internacionais de aviação civil, observados os acordos, tratados e convenções internacionais de que seja parte a República Federativa do Brasil; XI - expedir regras sobre segurança em área aeroportuária e a bordo de aeronaves civis, porte e transporte de cargas perigosas, inclusive o porte ou transporte de armamento, explosivos, material bélico ou de quaisquer outros produtos, substâncias ou objetos que possam pôr em risco os tripulantes ou passageiros, ou a própria aeronave ou, ainda, que sejam nocivos à saúde; XXV estabelecer o regime tarifário da exploração da infraestrutura aeroportuária, no todo ou em parte; XXIX expedir normas e padrões que assegurem a compatibilidade, a operação integrada e a interconexão de informações entre aeródromos; XXX - expedir normas e estabelecer padrões mínimos de segurança de voo, de desempenho e eficiência, a serem cumpridos pelas prestadoras de serviços aéreos e de infraestrutura aeronáutica e aeroportuária, inclusive quanto a equipamentos, materiais, produtos e processos que utilizarem e serviços que prestarem; XLVI - editar e dar publicidade às instruções e aos regulamentos necessários à aplicação desta Lei."

111 "Art. 11. Compete à Diretoria: V - exercer o poder normativo da Agência."

112 "Art. $8^{\circ}$ Cabe à ANAC adotar as medidas necessárias para o atendimento do interesse público e para o desenvolvimento e fomento da aviação civil, da infraestrutura aeronáutica e aeroportuária do País, atuando com independência, legalidade, impessoalidade e publicidade, competindo-lhe: VII - regular e fiscalizar a operação de serviços aéreos prestados, no País, por empresas estrangeiras, observados os acordos, tratados e convenções internacionais de que seja parte a República Federativa do Brasil; X regular e fiscalizar os serviços aéreos, os produtos e processos aeronáuticos, a formação e o treinamento de pessoal especializado, os serviços auxiliares, a segurança da aviação civil, a facilitação do transporte aéreo, a habilitação de tripulantes, as emissões de poluentes e o ruído aeronáutico, os sistemas de reservas, a movimentação de passageiros e carga e as demais atividades de aviação civil; XII - regular e fiscalizar as medidas a serem adotadas pelas empresas prestadoras de serviços aéreos, e exploradoras de infraestrutura aeroportuária, para prevenção quanto ao uso por seus tripulantes ou pessoal técnico de manutenção e operação que tenha acesso às aeronaves, de substâncias entorpecentes ou psicotrópicas, que possam determinar dependência física ou psíquica, permanente ou transitória; XIII - regular e fiscalizar a outorga de serviços aéreos; XVI - fiscalizar as aeronaves civis, seus componentes, equipamentos e serviços de manutenção, com o objetivo de assegurar o cumprimento das normas de segurança de voo; XXI - regular e fiscalizar a infraestrutura aeronáutica e aeroportuária, com exceção das atividades e procedimentos relacionados com o sistema de controle do espaço aéreo e com o sistema de investigação e prevenção de acidentes aeronáuticos; XXVIII - fiscalizar a observância dos requisitos técnicos na construção, reforma e ampliação de aeródromos e aprovar sua abertura ao tráfego; XXXII - regular, fiscalizar e autorizar os serviços aéreos prestados por aeroclubes, escolas e cursos de aviação civil."

113 “Art. $8^{\circ}$ Cabe à ANAC adotar as medidas necessárias para o atendimento do interesse público e para o desenvolvimento e fomento da aviação civil, da infraestrutura aeronáutica e aeroportuária do País, atuando com independência, legalidade, impessoalidade e publicidade, competindo-lhe: XXXV reprimir infrações à legislação, inclusive quanto aos direitos dos usuários, e aplicar as sanções cabíveis."

114 "Art. 11. Compete à Diretoria: VIII - apreciar, em grau de recurso, as penalidades impostas pela ANAC."

115 "Art. $3^{\circ}$ A Anac, no exercício de suas competências, deverá observar e implementar as orientações, diretrizes e políticas estabelecidas pelo governo federal, especialmente no que se refere a: III - a outorga de serviços aéreos." 
116 “Art. $6^{\circ}$ Com o objetivo de harmonizar suas ações institucionais na área da defesa e promoção da concorrência, a ANAC celebrará convênios com os órgãos e entidades do Governo Federal, competentes sobre a matéria."

117 “Art. $8^{\circ}$ Cabe à ANAC adotar as medidas necessárias para o atendimento do interesse público e para o desenvolvimento e fomento da aviação civil, da infraestrutura aeronáutica e aeroportuária do País, atuando com independência, legalidade, impessoalidade e publicidade, competindo-lhe: V - negociar o estabelecimento de acordos e tratados sobre transporte aéreo internacional, observadas as diretrizes do CONAC; XIV - conceder, permitir ou autorizar a exploração de serviços aéreos; XVII - proceder à homologação e emitir certificados, atestados, aprovações e autorizações, relativos às atividades de competência do sistema de segurança de voo da aviação civil, bem como licenças de tripulantes e certificados de habilitação técnica e de capacidade física e mental, observados os padrões e normas por ela estabelecidos; XXII - aprovar os planos diretores dos aeroportos; XXIV - conceder ou autorizar a exploração da infraestrutura aeroportuária, no todo ou em parte; XXXIII - expedir, homologar ou reconhecer a certificação de produtos e processos aeronáuticos de uso civil, observados os padrões e normas por ela estabelecidos; XLVIII - firmar convênios de cooperação técnica e administrativa com órgãos e entidades governamentais, nacionais ou estrangeiros, tendo em vista a descentralização e fiscalização eficiente dos setores de aviação civil e infraestrutura aeronáutica e aeroportuária."

118 “Art. 11. Compete à Diretoria: III - conceder, permitir ou autorizar a prestação de serviços aéreos; IV conceder ou autorizar a exploração da infraestrutura aeronáutica e aeroportuária."

119 “Art. $8^{\circ}$ Cabe à ANAC adotar as medidas necessárias para o atendimento do interesse público e para o desenvolvimento e fomento da aviação civil, da infraestrutura aeronáutica e aeroportuária do País, atuando com independência, legalidade, impessoalidade e publicidade, competindo-lhe: III - elaborar relatórios e emitir pareceres sobre acordos, tratados, convenções e outros atos relativos ao transporte aéreo internacional, celebrados ou a ser celebrados com outros países ou organizações internacionais. $\S 2^{\circ}$ A ANAC observará as prerrogativas específicas da Autoridade Aeronáutica, atribuídas ao Comandante da Aeronáutica, devendo ser previamente consultada sobre a edição de normas e procedimentos de controle do espaço aéreo que tenham repercussão econômica ou operacional na prestação de serviços aéreos e de infraestrutura aeronáutica e aeroportuária."

120 "Art. $8^{\circ}$ Cabe à ANAC adotar as medidas necessárias para o atendimento do interesse público e para o desenvolvimento e fomento da aviação civil, da infraestrutura aeronáutica e aeroportuária do País, atuando com independência, legalidade, impessoalidade e publicidade, competindo-lhe: XX - compor, administrativamente, conflitos de interesses entre prestadoras de serviços aéreos e de infraestrutura aeronáutica e aeroportuária."

121 “Art. 5 $5^{\circ}$ Têm legitimidade para propor a ação principal e a ação cautelar: IV - a autarquia, empresa pública, fundação ou sociedade de economia mista. $\S 6^{\circ}$ Os órgãos públicos legitimados poderão tomar dos interessados compromisso de ajustamento de sua conduta às exigências legais, mediante cominações, que terá eficácia de título executivo extrajudicial."

122 "Art. 68. As sanções, a serem aplicadas por autoridade competente, terão natureza pecuniária ou consistirão em obrigação de fazer ou de não fazer, assegurado sempre o direito de defesa."

123 “Art. $3^{\circ}$ Além das atribuições previstas nos incisos II, III, V, VI, VII, X, XI e XII do art. 29 e no art. 30 da Lei no 8.987, de 13 de fevereiro de 1995, de outras incumbências expressamente previstas em lei e observado o disposto no $\S 1^{\circ}$, compete à ANEEL: VI - fixar os critérios para cálculo do preço de transporte de que trata o $\S 60$ do art. 15 da Lei no 9.074, de 7 de julho de 1995, e arbitrar seus valores nos casos de negociação frustrada entre os agentes envolvidos; XIV - aprovar as regras e os procedimentos de comercialização de energia elétrica, contratada de formas regulada e livre."

124 “Art. $1^{\circ}$ A partir de 12 de setembro de 2012, as concessões de geração de energia hidrelétrica alcançadas pelo art. 19 da Lei $\mathrm{n}^{\circ}$ 9.074, de 7 de julho de 1995, poderão ser prorrogadas, a critério do poder concedente, uma única vez, pelo prazo de até 30 (trinta) anos, de forma a assegurar a continuidade, a eficiência da prestação do serviço e a modicidade tarifária. $\S 6^{\circ}$ Caberá à Aneel disciplinar a realização de investimentos que serão considerados nas tarifas, com vistas a manter a qualidade e continuidade da prestação do serviço pelas usinas hidrelétricas, conforme regulamento do poder concedente. $\S 12$. Caberá à Aneel a definição do procedimento de que tratam os $\S \S 10$ e 11 , conforme regulamento do poder concedente."

125 "§ $1^{\circ}$ As instalações de transmissão de energia elétrica componentes da rede básica do Sistema Interligado Nacional - SIN serão objeto de concessão, mediante licitação, na modalidade de concorrência ou de leilão e funcionarão integradas ao sistema elétrico, com regras operativas aprovadas pela Aneel, de forma a assegurar a otimização dos recursos eletroenergéticos existentes ou futuros. $\S 7^{\circ}$ As instalações de transmissão necessárias aos intercâmbios internacionais de energia elétrica outorgadas até 31 de dezembro de 2010 poderão ser equiparadas, para efeitos técnicos e comerciais, aos concessionários de 
serviço público de transmissão de que trata o $\S 60$, conforme regulação da Aneel, que definirá, em especial, a receita do agente, as tarifas de que tratam os incisos XVIII e XX do art. 3o da Lei no 9.427, de 26 de dezembro de 1996, e a forma de ajuste dos contratos atuais de importação e exportação de energia."

126 “Art. 2 ${ }^{\circ}$ A Agência Nacional de Energia Elétrica - ANEEL tem por finalidade regular e fiscalizar a produção, transmissão, distribuição e comercialização de energia elétrica, em conformidade com as políticas e diretrizes do governo federal."

127 “Art. $3^{\circ}$ Além das atribuições previstas nos incisos II, III, V, VI, VII, X, XI e XII do art. 29 e no art. 30 da Lei no 8.987, de 13 de fevereiro de 1995, de outras incumbências expressamente previstas em lei e observado o disposto no $\S 1^{\circ}$, compete à ANEEL: IV - gerir os contratos de concessão ou de permissão de serviços públicos de energia elétrica, de concessão de uso de bem público, bem como fiscalizar, diretamente ou mediante convênios com órgãos estaduais, as concessões, as permissões e a prestação dos serviços de energia elétrica; IX - zelar pelo cumprimento da legislação de defesa da concorrência, monitorando e acompanhando as práticas de mercado dos agentes do setor de energia elétrica; XIII efetuar o controle prévio e a posteriori de atos e negócios jurídicos a serem celebrados entre concessionárias, permissionárias, autorizadas e seus controladores, suas sociedades controladas ou coligadas e outras sociedades controladas ou coligadas de controlador comum, impondo-lhes restrições à mútua constituição de direitos e obrigações, especialmente comerciais e, no limite, a abstenção do próprio ato ou contrato; XIX - regular o serviço concedido, permitido e autorizado e fiscalizar permanentemente sua prestação."

128 “Art. $4^{\circ}$ Fica autorizada a criação da Câmara de Comercialização de Energia Elétrica - CCEE, pessoa jurídica de direito privado, sem fins lucrativos, sob autorização do Poder Concedente e regulação e fiscalização pela Agência Nacional de Energia Elétrica - ANEEL, com a finalidade de viabilizar a comercialização de energia elétrica de que trata esta Lei.’

129 "Parágrafo único. A ANEEL deverá regular e fiscalizar o processo de adequação do ONS à regulamentação prevista no art. 14 da Lei no 9.648, de 27 de maio de 1998, com a redação dada por esta Lei, incluindo o critério de não-coincidência de mandatos de diretores, no prazo máximo de 90 (noventa) dias, contados da publicação da regulamentação desta Lei, nos termos do art. 27 desta Lei."

130 “Art. $3^{\circ}$ Além das atribuições previstas nos incisos II, III, V, VI, VII, X, XI e XII do art. 29 e no art. 30 da Lei no 8.987, de 13 de fevereiro de 1995, de outras incumbências expressamente previstas em lei e observado o disposto no $\S 1^{\circ}$, compete à ANEEL: X - fixar as multas administrativas a serem impostas aos concessionários, permissionários e autorizados de instalações e serviços de energia elétrica, observado o limite, por infração, de $2 \%$ (dois por cento) do faturamento, ou do valor estimado da energia produzida nos casos de autoprodução e produção independente, correspondente aos últimos doze meses anteriores à lavratura do auto de infração ou estimados para um período de doze meses caso o infrator não esteja em operação ou esteja operando por um período inferior a doze meses."

131 “Art. 17. A Aneel poderá estabelecer regime excepcional de sanções regulatórias durante o período de prestação temporária do serviço público de energia elétrica de que trata o art. 2o e nas hipóteses de intervenção."

132 “Art. $3^{\circ}$ Além das atribuições previstas nos incisos II, III, V, VI, VII, X, XI e XII do art. 29 e no art. 30 da Lei no 8.987, de 13 de fevereiro de 1995, de outras incumbências expressamente previstas em lei e observado o disposto no $\S 1^{\circ}$, compete à ANEEL: II - promover, mediante delegação, com base no plano de outorgas e diretrizes aprovadas pelo Poder Concedente, os procedimentos licitatórios para a contratação de concessionárias e permissionárias de serviço público para produção, transmissão e distribuição de energia elétrica e para a outorga de concessão para aproveitamento de potenciais hidráulicos; XV - promover processos licitatórios para atendimento às necessidades do mercado."

133 “Art. 20. Sem prejuízo do disposto na alínea b do inciso XII do art. 21 e no inciso XI do art. 23 da Constituição Federal, a execução das atividades complementares de regulação, controle e fiscalização dos serviços e instalações de energia elétrica poderá ser descentralizada pela União para os Estados e para o Distrito Federal visando à gestão associada de serviços públicos, mediante convênio de cooperação. $\S 3^{\circ}$ A execução pelos Estados e Distrito Federal das atividades delegadas será disciplinada por meio de contrato de metas firmado entre a Aneel e a Agência Estadual ou Distrital, conforme regulamentação da Aneel, que observará os seguintes parâmetros: I - controle de resultado voltado para a eficiência da gestão; II - contraprestação baseada em custos de referência; III - vinculação ao Convênio de Cooperação firmado por prazo indeterminado."

134 “Art. $4^{\circ}$ As concessões, permissões e autorizações de exploração de serviços e instalações de energia elétrica e de aproveitamento energético dos cursos de água serão contratadas, prorrogadas ou outorgadas nos termos desta e da Lei $n^{0} 8.987$, e das demais. § 10. Fica a Agência Nacional de Energia Elétrica ANEEL autorizada a celebrar aditivos aos contratos de concessão de uso de bem público de aproveitamentos de potenciais hidráulicos feitos a título oneroso em favor da União, mediante solicitação 
do respectivo titular, com a finalidade de permitir que o início do pagamento pelo uso de bem público coincida com uma das seguintes situações, a que ocorrer primeiro: I - o início da entrega da energia objeto de Contratos de Comercialização de Energia no Ambiente Regulado - CCEAR; ou II - a efetiva entrada em operação comercial do aproveitamento. $\S 11$. Quando da solicitação de que trata o $\S 10$ deste artigo resultar postergação do início de pagamento pelo uso de bem público, a celebração do aditivo contratual estará condicionada à análise e à aceitação pela ANEEL das justificativas apresentadas pelo titular da concessão para a postergação solicitada. § 13. As concessionárias do serviço público de distribuição de energia elétrica poderão, conforme regulação da Aneel, negociar com consumidores de que tratam os arts. 15 e 16 desta Lei, afastada a vedação de que trata o inciso III do $\S 50$, contratos de venda de energia elétrica lastreados no excesso de energia contratada para atendimento à totalidade do mercado."

135 “Art. 10. Cabe à Agência Nacional de Energia Elétrica - ANEEL, declarar a utilidade pública, para fins de desapropriação ou instituição de servidão administrativa, das áreas necessárias à implantação de instalações de concessionários, permissionários e autorizados de energia elétrica."

136 “Art. $3^{\circ}$ Caberá à Aneel, conforme regulamento do poder concedente, instituir mecanismo para compensar as variações no nível de contratação das concessionárias e permissionárias de distribuição do SIN, decorrentes da alocação de cotas a que se refere o inciso II do $\S 1$ o do art. $1^{\circ}$."

137 “Art. 13. Na antecipação dos efeitos da prorrogação de que trata o art. 12, o poder concedente definirá, conforme regulamento, a tarifa ou receita inicial para os concessionários de geração, transmissão e distribuição. $\S 1^{\circ}$ A Aneel realizará revisão extraordinária das tarifas de uso dos sistemas de transmissão para contemplar a receita a que se refere o caput. $\S 2^{\circ} \mathrm{A}$ Aneel procederá à revisão tarifária extraordinária das concessionárias de distribuição de energia elétrica, sem prejuízo do reajuste tarifário anual previsto nos contratos de concessão, para contemplar as tarifas a que se refere este artigo."

138 “Art. $5^{\circ} \mathrm{O}$ poder concedente, por intermédio da Aneel, poderá intervir na concessão de serviço público de energia elétrica, com o fim de assegurar sua prestação adequada e o fiel cumprimento das normas contratuais, regulamentares e legais pertinentes."

139 “Art. 13. O deferimento pela Aneel do plano de recuperação e correção das falhas e transgressões cessará a intervenção, devendo a concessionária: I - apresentar certidão de regularidade físcal com a Fazenda Federal e o Fundo de Garantia do Tempo de Serviço - FGTS, no prazo de 180 (cento e oitenta) dias; e II enviar trimestralmente à Aneel relatório sobre o cumprimento do plano de recuperação e correção das falhas e transgressões até a sua efetiva conclusão."

140 "§ $2^{\circ}$ A contratação regulada de que trata o caput deste artigo deverá ser formalizada por meio de contratos bilaterais denominados Contrato de Comercialização de Energia no Ambiente Regulado CCEAR, celebrados entre cada concessionária ou autorizada de geração e todas as concessionárias, permissionárias e autorizadas do serviço público de distribuição, devendo ser observado o seguinte: IV o início da entrega da energia objeto dos CCEARs poderá ser antecipado, mantido o preço e os respectivos critérios de reajuste, com vistas no atendimento à quantidade demandada pelos compradores, cabendo à ANEEL disciplinar os ajustes nos contratos, de acordo com diretrizes do Ministério de Minas e Energia. § 11. As licitações para contratação de energia elétrica de que trata este artigo serão reguladas e realizadas pela Agência Nacional de Energia Elétrica - ANEEL, observado o disposto no art. $3^{\circ}$-A da Lei $n^{\circ}$ 9.427, de 26 de dezembro de 1996, com a redação dada por esta Lei, que poderá promovê-las diretamente ou por intermédio da Câmara de Comercialização de Energia Elétrica - CCEE."

141 “Art. $2^{\circ}$-B. Na contratação da geração distribuída prevista na alínea a do inciso II do $\S 80$ do art. 2o, a Aneel autorizará o repasse integral dos custos de aquisição de energia elétrica pelos agentes de distribuição para a tarifa de seus consumidores finais, até o maior valor entre o Valor Anual de Referência - VR e o Valor Anual de Referência Específico - VRES."

142 “§ $5^{\circ}$ A recomposição tarifária extraordinária estará sujeita a homologação pela Aneel e observará as seguintes regras:"

143 "§ 16. Caberá à Aneel dirimir conflitos entre compradores e vendedores de energia elétrica, que tenham celebrado CCEARs, utilizando lastro em contratos de importação de energia elétrica ou à base de gás natural, cujas obrigações tenham sido alteradas em face de acontecimentos extraordinários e imprevisíveis, decorrentes de eventos alheios à vontade do vendedor, nos termos do inciso $\mathrm{V}$ do art. $3^{\circ}$ da Lei $n^{\circ} 9.427$, de 26 de dezembro de 1996."

144 “Art. $3^{\circ}$ Além das atribuições previstas nos incisos II, III, V, VI, VII, X, XI e XII do art. 29 e no art. 30 da Lei no 8.987, de 13 de fevereiro de 1995, de outras incumbências expressamente previstas em lei e observado o disposto no $\S 1^{\circ}$, compete à ANEEL: $\mathrm{V}$ - dirimir, no âmbito administrativo, as divergências entre concessionárias, permissionárias, autorizadas, produtores independentes e autoprodutores, bem como entre esses agentes e seus consumidores." 
145 “Art. $6^{\circ}$ Declarada a intervenção na concessão de serviço público de energia elétrica, a Aneel deverá, no prazo de 30 (trinta) dias, instaurar procedimento administrativo para comprovar as causas determinantes da medida e apurar responsabilidades, assegurado o direito de ampla defesa."

146 "V - para atender aos fins previstos no inciso IV, a homologação da recomposição tarifária extraordinária estará condicionada, nos termos de resolução da Aneel, à solução de controvérsias contratuais e normativas e à eliminação e prevenção de eventuais litígios judiciais ou extrajudiciais, inclusive por meio de arbitragem levada a efeito pela Aneel. $\S 8^{\circ}$ Os contratos iniciais e equivalentes, assim reconhecidos em resolução da Aneel, serão aditados para contemplar uma fórmula compulsória de solução de controvérsias, para que a Aneel instaure ex officio, caso as partes não o façam em prazo determinado, os mecanismos de solução de controvérsias existentes, sem prejuízo da atuação subsidiária da Aneel na arbitragem de controvérsias."

147 "Art. $5^{\circ}$ Têm legitimidade para propor a ação principal e a ação cautelar: IV - a autarquia, empresa pública, fundação ou sociedade de economia mista. $\S 6^{\circ}$ Os órgãos públicos legitimados poderão tomar dos interessados compromisso de ajustamento de sua conduta às exigências legais, mediante cominações, que terá eficácia de título executivo extrajudicial."

148 "Art. 68. As sanções, a serem aplicadas por autoridade competente, terão natureza pecuniária ou consistirão em obrigação de fazer ou de não fazer, assegurado sempre o direito de defesa." 


\section{APÊNDICE B - LEVANTAMENTO DOS DISPOSITIVOS LEGAIS QUE DISCIPLINAM A AUTONOMIA DAS AGÊNCIAS REGULADORAS}

\section{ANEEL:}

Dispositivos normativos referentes a:

1.1. Estabilidade dos dirigentes e "quarentena": art. $6^{\circ}$, caput e $\S$ único ${ }^{343}, 9^{\circ 344}, 10^{345}$, $29^{346}$ da Lei $n^{\circ}$ 9.427/1996.

1.2. Ausência de controle hierárquico.

1.3. Autonomia financeira: arts. $3^{\circ}, \S 2^{0347}, 33^{348}$ da Lei $n^{\circ} 9.427 / 1996,22^{349}$ da Lei $n^{\text {o }}$ $9.986 / 2000$.

343 “Art. $6^{\circ}$ Está impedida de exercer cargo de direção na ANEEL a pessoa que mantiver os seguintes vínculos com qualquer empresa concessionária, permissionária, autorizada, produtor independente, autoprodutor ou prestador de serviço contratado dessas empresas sob regulamentação ou fiscalização da autarquia: I - acionista ou sócio com participação individual direta superior a três décimos por cento no capital social ou superior a dois por cento no capital social de empresa controladora; II - membro do conselho de administração, fiscal ou de diretoria executiva; III - empregado, mesmo com o contrato de trabalho suspenso, inclusive das empresas controladoras ou das fundações de previdência de que sejam patrocinadoras.

Parágrafo único. Também está impedido de exercer cargo de direção da ANEEL membro do conselho ou diretoria de associação regional ou nacional, representativa de interesses dos agentes mencionados no caput, de categoria profissional de empregados desses agentes, bem como de conjunto ou classe de consumidores de energia."

344 “Art. 9 $\mathrm{O}$ ex-dirigente da ANEEL continuará vinculado à autarquia nos doze meses seguintes ao exercício do cargo, durante os quais estará impedido de prestar, direta ou indiretamente, independentemente da forma ou natureza do contrato, qualquer tipo de serviço às empresas sob sua regulamentação ou fiscalização, inclusive controladas, coligadas ou subsidiárias."

345 “Art. 10. Os cargos em comissão da autarquia serão exercidos, preferencialmente, por servidores ocupantes de cargo de carreira técnica ou profissional da autarquia, aplicando-se-lhes as mesmas restrições do art. 6o quando preenchidos por pessoas estranhas aos quadros da ANEEL, exceto no período a que se refere o art. 29."

346 “Art. 29. Na primeira gestão da autarquia, visando implementar a transição para o sistema de mandatos não coincidentes, o Diretor-Geral e dois Diretores serão nomeados pelo Presidente da República, por indicação do Ministério de Minas e Energia, e dois Diretores nomeados na forma do disposto no parágrafo único do art. $5^{\circ} . "$

347 "Art. $3^{\circ}$ Além das atribuições previstas nos incisos II, III, V, VI, VII, X, XI e XII do art. 29 e no art. 30 da Lei no 8.987, de 13 de fevereiro de 1995, de outras incumbências expressamente previstas em lei e observado o disposto no $\S 1^{\circ}$, compete à ANEEL: $\S 2^{\circ}$ No exercício da competência prevista no inciso XI, a Aneel deverá definir o valor da subvenção prevista no inciso XIII do art. 13 da Lei no 10.438 , de 26 de abril de 2002, a ser recebida por cooperativas de eletrificação rural, concessionárias ou permissionárias, para compensar a reduzida densidade de carga de seu mercado, quando for o caso."

348 “Art. 33. No prazo máximo de vinte e quatro meses, a contar da sua organização, a ANEEL promoverá a simplificação do Plano de Contas específico para as empresas concessionárias de serviços públicos de energia elétrica, com a segmentação das contas por tipo de atividade de geração, transmissão e distribuição."

349 “Art. 22. Ficam as Agências autorizadas a custear as despesas com remoção e estada para os profissionais que, em virtude de nomeação para Cargos Comissionados de Direção, de Gerência Executiva e de Assessoria dos níveis CD I e II, CGE I, II, III e IV, CA I e II, e para os Cargos Comissionados Técnicos, nos níveis CCT V e IV, vierem a ter exercício em cidade diferente da de seu domicílio, conforme disposto em regulamento de cada Agência, observados os limites de valores estabelecidos para a Administração Pública Federal direta." 
1.4. Autonomia de gestão: art. $3^{\circ}$, $\mathrm{I}^{350}$, da Lei $\mathrm{n}^{\mathrm{o}} 9.427 / 1996,31^{351}$ da Lei $\mathrm{n}^{\mathrm{o}}$ 9.986/2000.

1.5. Prerrogativa de organização de seus serviços: art. $4^{0352}$ da Lei $n^{0} 9.427 / 1996$.

1.6. Regime de pessoal específico (normas que indiquem se a agência tem o comando — ou não — de sua política de pessoal): art. $2^{\mathrm{o} 353}, 14^{354}, 19, \S \S 3^{\mathrm{o}}$ e $4^{\mathrm{o} 355}, 29^{356} \mathrm{da}$ Lei $n^{\circ} 9.986 / 2000$.

350 “Art. $3^{\circ}$ Além das atribuições previstas nos incisos II, III, V, VI, VII, X, XI e XII do art. 29 e no art. 30 da Lei no 8.987, de 13 de fevereiro de 1995, de outras incumbências expressamente previstas em lei e observado o disposto no $\S 1^{\circ}$, compete à ANEEL: I - implementar as políticas e diretrizes do governo federal para a exploração da energia elétrica e o aproveitamento dos potenciais hidráulicos, expedindo os atos regulamentares necessários ao cumprimento das normas estabelecidas pela Lei $\mathrm{n}^{\circ} 9.074$, de 7 de julho de 1995."

351 “Art. 31. As Agências Reguladoras, no exercício de sua autonomia, poderão desenvolver sistemas próprios de administração de recursos humanos, inclusive cadastro e pagamento, sendo obrigatória a alimentação dos sistemas de informações mantidos pelo órgão central do Sistema de Pessoal Civil SIPEC."

352 “Art. 4 A ANEEL será dirigida por um Diretor-Geral e quatro Diretores, em regime de colegiado, cujas funções serão estabelecidas no ato administrativo que aprovar a estrutura organizacional da autarquia."

353 “Art. $2^{\circ}$ Ficam criados, para exercício exclusivo nas Agências Reguladoras, os cargos Comissionados de Direção - CD, de Gerência Executiva - CGE, de Assessoria - CA e de Assistência - CAS, e os Cargos Comissionados Técnicos - CCT, constantes do Anexo I desta Lei."

354 “Art. 14. Os quantitativos dos empregos públicos e dos cargos comissionados de cada Agência serão estabelecidos em lei, ficando as Agências autorizadas a efetuar a alteração dos quantitativos e da distribuição dos Cargos Comissionados de Gerência Executiva, de Assessoria, de Assistência e dos Cargos Comissionados Técnicos, observados os valores de retribuição correspondentes e desde que não acarrete aumento de despesa."

355 “Art. 19. Mediante lei, poderão ser criados Quadro de Pessoal Específico, destinado, exclusivamente, à absorção de servidores públicos federais regidos pela Lei no 8.112, de 11 de dezembro de 1990, e Quadro de Pessoal em Extinção, destinado exclusivamente à absorção de empregados de empresas públicas federais liquidadas ou em processo de liquidação, regidos pelo regime celetista, que se encontrarem exercendo atividades a serem absorvidas pelas Agências.

$\S 3^{\circ}$ À medida que forem extintos os cargos ou empregos dos Quadros de que trata este artigo, é facultado à Agência o preenchimento de empregos de pessoal concursado para o Quadro de Pessoal Efetivo.

$\S 4^{\circ}$ Se o quantitativo de cargos ou empregos dos Quadros de que trata este artigo for inferior ao Quadro de Pessoal Efetivo, é facultada à Agência a realização de concurso para preenchimento dos empregos excedentes."

356 “Art. 29. Fica criado, dentro do limite quantitativo do Quadro Efetivo da ANATEL, ANEEL, ANP e ANS, Quadro de Pessoal Específico a que se refere o art. 19, composto por servidores que tenham sido redistribuídos para as Agências até a data da promulgação desta Lei." 


\section{ANATEL:}

Dispositivos normativos referentes a:

2.1. Estabilidade dos dirigentes e "quarentena": art. $8^{\mathrm{o}}, \S 2^{\mathrm{o} 357}, 24^{358}, 25^{359}, 30^{360} \mathrm{da}$ LGT.

2.2. Ausência de controle hierárquico: arts. $8^{\circ}, \S 2^{\circ}, 32$, caput ${ }^{361}$, da LGT.

2.3. Autonomia financeira: arts. $8^{\circ}, \S 2^{\circ}, 19, \mathrm{XXI}^{362}, 49, \S \S 1^{\mathrm{o}}, 2^{\mathrm{o}}, 3^{\mathrm{o}}$ e $4^{\mathrm{o} 363}, 50^{364} \mathrm{da}$ LGT, $22^{365}$ da Lei $n^{\circ}$ 9.986/2000.

2.4. Autonomia de gestão: arts. $8^{\circ}, \S 2^{\circ}, 19, X_{\text {XII, }} X_{X I V}^{366}$, da LGT, $31^{367}$ da Lei $n^{\circ}$ $9.986 / 2000$.

357 “Art. $8^{\circ}$ Fica criada a Agência Nacional de Telecomunicações, entidade integrante da Administração Pública Federal indireta, submetida a regime autárquico especial e vinculada ao Ministério das Comunicações, com a função de órgão regulador das telecomunicações, com sede no Distrito Federal, podendo estabelecer unidades regionais. $\S 2^{\circ}$ A natureza de autarquia especial conferida à Agência é caracterizada por independência administrativa, ausência de subordinação hierárquica, mandato fixo e estabilidade de seus dirigentes e autonomia financeira."

358 “Art. 24. O mandato dos membros do Conselho Diretor será de cinco anos. Parágrafo único: Em caso de vaga no curso do mandato, este será completado por sucessor investido na forma prevista no artigo anterior, que o exercerá pelo prazo remanescente."

359 “Art. 25. Os mandatos dos primeiros membros do Conselho Diretor serão de três, quatro, cinco, seis e sete anos, a serem estabelecidos no decreto de nomeação."

360 “Art. 30. Até um ano após deixar o cargo, é vedado ao ex-conselheiro representar qualquer pessoa ou interesse perante a Agência."

361 “Art. 32. Cabe ao Presidente a representação da Agência, o comando hierárquico sobre o pessoal e o serviço, exercendo todas as competências administrativas correspondentes, bem como a presidência das sessões do Conselho Diretor."

362 “Art. 19. À Agência compete adotar as medidas necessárias para o atendimento do interesse público e para o desenvolvimento das telecomunicações brasileiras, atuando com independência, imparcialidade, legalidade, impessoalidade e publicidade, e especialmente: XXI - arrecadar e aplicar suas receitas;"

363 “Art. 49. A Agência submeterá anualmente ao Ministério das Comunicações a sua proposta de orçamento, bem como a do FISTEL, que serão encaminhadas ao Ministério do Planejamento e Orçamento para inclusão no projeto de lei orçamentária anual a que se refere o $\S 5^{\circ}$ do art. 165 da Constituição Federal. $\S 1^{\circ}$ A Agência fará acompanhar as propostas orçamentárias de um quadro demonstrativo do planejamento plurianual das receitas e despesas, visando ao seu equilíbrio orçamentário e financeiro nos cinco exercícios subsequentes. $\S 2^{\circ} \mathrm{O}$ planejamento plurianual preverá o montante a ser transferido ao fundo de universalização a que se refere o inciso II do art. 81 desta Lei, e os saldos a serem transferidos ao Tesouro Nacional. $\S 3^{\circ}$ A lei orçamentária anual consignará as dotações para as despesas de custeio e capital da Agência, bem como o valor das transferências de recursos do FISTEL ao Tesouro Nacional e ao fundo de universalização, relativos ao exercício a que ela se referir. $\S 4^{\circ}$ As transferências a que se refere o parágrafo anterior serão formalmente feitas pela Agência ao final de cada mês."

364 “Art. 50. O Fundo de Fiscalização das Telecomunicações - FISTEL, criado pela Lei n 5.070, de 7 de julho de 1966, passará à administração exclusiva da Agência, a partir da data de sua instalação, com os saldos nele existentes, incluídas as receitas que sejam produto da cobrança a que se refere o art. 14 da Lei no 9.295, de 19 de julho de 1996."

365 “Art. 22. Ficam as Agências autorizadas a custear as despesas com remoção e estada para os profissionais que, em virtude de nomeação para Cargos Comissionados de Direção, de Gerência Executiva e de Assessoria dos níveis CD I e II, CGE I, II, III e IV, CA I e II, e para os Cargos Comissionados Técnicos, nos níveis CCT V e IV, vierem a ter exercício em cidade diferente da de seu domicílio, conforme disposto em regulamento de cada Agência, observados os limites de valores estabelecidos para a Administração Pública Federal direta." 
2.5. Prerrogativa de organização de seus serviços: arts. 19, caput, XXVII ${ }^{368}, 22$, XII $^{369}$, $59^{370}, 103^{371}, 151^{372}$ da LGT, $32, \S 7^{\text {o373 }}$, da Lei $n^{\mathrm{o}} 11.652 / 2008$.

2.6. Regime de pessoal específico: arts. $19, \mathrm{XXIII}^{374}$, da LGT, $2^{0375}, 14^{376}, 19, \S \S 3^{\circ} \mathrm{e}$ $4^{\text {o377 }}, 29^{378}$ da Lei n 9 $^{\text {9.986/2000. }}$

366 "Art. 19. À Agência compete adotar as medidas necessárias para o atendimento do interesse público e para o desenvolvimento das telecomunicações brasileiras, atuando com independência, imparcialidade, legalidade, impessoalidade e publicidade, e especialmente: XVII - compor administrativamente conflitos de interesses entre prestadoras de serviço de telecomunicações; XXIV - adquirir, administrar e alienar seus bens."

367 "Art. 31. As Agências Reguladoras, no exercício de sua autonomia, poderão desenvolver sistemas próprios de administração de recursos humanos, inclusive cadastro e pagamento, sendo obrigatória a alimentação dos sistemas de informações mantidos pelo órgão central do Sistema de Pessoal Civil SIPEC."

368 "Art. 19. À Agência compete adotar as medidas necessárias para o atendimento do interesse público e para o desenvolvimento das telecomunicações brasileiras, atuando com independência, imparcialidade, legalidade, impessoalidade e publicidade, e especialmente: XXVII - aprovar o seu regimento interno."

369 "Art. 22. Compete ao Conselho Diretor: XII - autorizar a contratação de serviços de terceiros, na forma da legislação em vigor."

370 "Art. 59. A Agência poderá utilizar, mediante contrato, técnicos ou empresas especializadas, inclusive consultores independentes e auditores externos, para executar atividades de sua competência, vedada a contratação para as atividades de fiscalização, salvo para as correspondentes atividades de apoio."

371 "Art. 103. Compete à Agência estabelecer a estrutura tarifária para cada modalidade de serviço."

372 "Art. 151. A Agência disporá sobre os planos de numeração dos serviços, assegurando sua administração de forma não discriminatória e em estímulo à competição, garantindo o atendimento aos compromissos internacionais."

373 "Art. 32. Fica instituída a Contribuição para o Fomento da Radiodifusão Pública, com o objetivo de propiciar meios para a melhoria dos serviços de radiodifusão pública e para a ampliação de sua penetração mediante a utilização de serviços de telecomunicações. $\S 7^{\circ}$ À Agência Nacional de Telecomunicações - ANATEL compete planejar, executar, acompanhar e avaliar as atividades relativas a tributação, fiscalização, arrecadação, cobrança e recolhimento da contribuição prevista neste artigo, cabendo-lhe promover as demais atividades necessárias à sua administração."

374 "Art. 19. À Agência compete adotar as medidas necessárias para o atendimento do interesse público e para o desenvolvimento das telecomunicações brasileiras, atuando com independência, imparcialidade, legalidade, impessoalidade e publicidade, e especialmente: XXIII - contratar pessoal por prazo determinado, de acordo com o disposto na Lei no 8.745 , de 9 de dezembro de 1993."

375 "Art. $2^{\circ}$ Ficam criados, para exercício exclusivo nas Agências Reguladoras, os cargos Comissionados de Direção - CD, de Gerência Executiva - CGE, de Assessoria - CA e de Assistência - CAS, e os Cargos Comissionados Técnicos - CCT, constantes do Anexo I desta Lei."

376 "Art. 14. Os quantitativos dos empregos públicos e dos cargos comissionados de cada Agência serão estabelecidos em lei, ficando as Agências autorizadas a efetuar a alteração dos quantitativos e da distribuição dos Cargos Comissionados de Gerência Executiva, de Assessoria, de Assistência e dos Cargos Comissionados Técnicos, observados os valores de retribuição correspondentes e desde que não acarrete aumento de despesa."

377 "Art. 19. Mediante lei, poderão ser criados Quadro de Pessoal Específico, destinado, exclusivamente, à absorção de servidores públicos federais regidos pela Lei no 8.112, de 11 de dezembro de 1990, e Quadro de Pessoal em Extinção, destinado exclusivamente à absorção de empregados de empresas públicas federais liquidadas ou em processo de liquidação, regidos pelo regime celetista, que se encontrarem exercendo atividades a serem absorvidas pelas Agências."

$\S 3^{\circ}$ À medida que forem extintos os cargos ou empregos dos Quadros de que trata este artigo, é facultado à Agência o preenchimento de empregos de pessoal concursado para o Quadro de Pessoal Efetivo.

$\S 4^{\circ} \mathrm{Se}$ o quantitativo de cargos ou empregos dos Quadros de que trata este artigo for inferior ao Quadro de Pessoal Efetivo, é facultada à Agência a realização de concurso para preenchimento dos empregos excedentes."

378 "Art. 29. Fica criado, dentro do limite quantitativo do Quadro Efetivo da ANATEL, ANEEL, ANP e ANS, Quadro de Pessoal Específico a que se refere o art. 19, composto por servidores que tenham sido redistribuídos para as Agências até a data da promulgação desta Lei." 


\section{ANP:}

Dispositivos normativos referentes a:

3.1. Estabilidade dos dirigentes e "quarentena": arts. $11, \S 3^{0379}, 14$, caput e $\S 2^{\mathrm{o}^{380}}$, $75^{381}$ da Lei $n^{\circ} 9.478 / 1997$.

3.2. Ausência de controle hierárquico.

3.3. Autonomia financeira: arts. $47, \S 1^{\mathrm{o}^{382}}, 51, \S$ único $^{383}$, da Lei $n^{\mathrm{o}} 9.478 / 1997,22^{384}$ da Lei ${ }^{\circ}$ 9.986/2000.

3.4. Autonomia de gestão: arts. $7^{\circ}, \S$ único ${ }^{385}, 8^{\circ}$, XX, XXVIII ${ }^{386}, 28, \S 1^{\text {o387 }}$, da Lei ${ }^{\text {o }}$ 9.478/1997, 34, caput e $\S 1^{1^{388}}$, da Lei $n^{\text {o }} 12.351 / 2010,31^{389}$ da Lei $n^{\circ} 9.986 / 2000$.

379 “Art. 11. A ANP será dirigida, em regime de colegiado, por uma Diretoria composta de um Diretor-Geral e quatro Diretores. $\S 3^{\circ}$ Os membros da Diretoria cumprirão mandatos de quatro anos, não coincidentes, permitida a recondução, observado o disposto no art. 75 desta Lei."

380 “Art. 14. Terminado o mandato, ou uma vez exonerado do cargo, o ex-Diretor da ANP ficará impedido, por um período de 12 (doze) meses, contado da data de sua exoneração, de prestar, direta ou indiretamente, qualquer tipo de serviço a empresa integrante das indústrias do petróleo e dos biocombustíveis ou de distribuição. $\S 2^{\circ}$ Incorre na prática de advocacia administrativa, sujeitando-se às penas da lei, o ex-Diretor que violar o impedimento previsto neste artigo."

381 “Art. 75. Na composição da primeira Diretoria da ANP, visando implementar a transição para o sistema de mandatos não coincidentes, o Diretor-Geral e dois Diretores serão nomeados pelo Presidente da República, por indicação do Ministro de Estado de Minas e Energia, respectivamente com mandatos de três, dois e um ano, e dois Diretores serão nomeados conforme o disposto nos $\S \S 2^{\circ}$ e $3^{\circ}$ do art. 11."

382 “Art. 47. Os royalties serão pagos mensalmente, em moeda nacional, a partir da data de início da produção comercial de cada campo, em montante correspondente a dez por cento da produção de petróleo ou gás natural. $\S 1^{\mathrm{o}}$ Tendo em conta os riscos geológicos, as expectativas de produção e outros fatores pertinentes, a ANP poderá prever, no edital de licitação correspondente, a redução do valor dos royalties estabelecido no caput deste artigo para um montante correspondente a, no mínimo, cinco por cento da produção."

383 "Art. 51. O edital e o contrato disporão sobre o pagamento pela ocupação ou retenção de área, a ser feito anualmente, fixado por quilômetro quadrado ou fração da superfície do bloco, na forma da regulamentação por decreto do Presidente da República. Parágrafo único. O valor do pagamento pela ocupação ou retenção de área será aumentado em percentual a ser estabelecido pela ANP, sempre que houver prorrogação do prazo de exploração."

384 "Art. 22. Ficam as Agências autorizadas a custear as despesas com remoção e estada para os profissionais que, em virtude de nomeação para Cargos Comissionados de Direção, de Gerência Executiva e de Assessoria dos níveis CD I e II, CGE I, II, III e IV, CA I e II, e para os Cargos Comissionados Técnicos, nos níveis CCT V e IV, vierem a ter exercício em cidade diferente da de seu domicílio, conforme disposto em regulamento de cada Agência, observados os limites de valores estabelecidos para a Administração Pública Federal direta."

385 “Art. $7^{\circ}$ Fica instituída a Agência Nacional do Petróleo, Gás Natural e Biocombustíves - ANP, entidade integrante da Administração Federal Indireta, submetida ao regime autárquico especial, como órgão regulador da indústria do petróleo, gás natural, seus derivados e biocombustíveis, vinculada ao Ministério de Minas e Energia. Parágrafo único. A ANP terá sede e foro no Distrito Federal e escritórios centrais na cidade do Rio de Janeiro, podendo instalar unidades administrativas regionais."

386 “Art. $8^{\circ}$ A ANP terá como finalidade promover a regulação, a contratação e a fiscalização das atividades econômicas integrantes da indústria do petróleo, do gás natural e dos biocombustíveis, cabendo-lhe: XX promover, direta ou indiretamente, as chamadas públicas para a contratação de capacidade de transporte de gás natural, conforme as diretrizes do Ministério de Minas e Energia; XVIII - articular-se com órgãos reguladores estaduais e ambientais, objetivando compatibilizar e uniformizar as normas aplicáveis à indústria e aos mercados de gás natural." 
3.5. Prerrogativa de organização de seus serviços: art. $21^{390}$ da Lei $n^{\circ} 9.478 / 1997$.

3.6. Regime de pessoal específico: art. $76^{391}$ da Lei $n^{\circ} 9.478 / 1997,2^{\circ}, 14,19, \S \S 3^{\circ}$ e $4^{\text {o }}, 29^{392}$ da Lei no $9.986 / 2000$.

\section{ANTT:}

\section{Dispositivos normativos referentes a:}

4.1. Estabilidade dos dirigentes e "quarentena": art. $21, \S 2^{\mathrm{o} 393}, 54^{394}, 56^{395}, 57^{396}, 58^{397}$ da Lei $n^{\circ} 10.233 / 2001$.

4.2. Ausência de controle hierárquico: art. $61^{398}$ da Lei $n^{\circ} 10.233 / 2001$.

387 “\$ $1^{\circ} \mathrm{A}$ devolução de áreas, assim como a reversão de bens, não implicará ônus de qualquer natureza para a União ou para a ANP, nem conferirá ao concessionário qualquer direito de indenização pelos serviços, poços, imóveis e bens reversíveis, os quais passarão à propriedade da União e à administração da ANP, na forma prevista no inciso VI do art. 43."

388 “Art. 34. A ANP regulará os procedimentos e as diretrizes para elaboração do acordo de individualização da produção, o qual estipulará: I - a participação de cada uma das partes na jazida individualizada, bem como as hipóteses e os critérios de sua revisão; II - o plano de desenvolvimento da área objeto de individualização da produção; e III - os mecanismos de solução de controvérsias.

Parágrafo único. A ANP acompanhará a negociação entre os interessados sobre os termos do acordo de individualização da produção."

389 “Art. 31. As Agências Reguladoras, no exercício de sua autonomia, poderão desenvolver sistemas próprios de administração de recursos humanos, inclusive cadastro e pagamento, sendo obrigatória a alimentação dos sistemas de informações mantidos pelo órgão central do Sistema de Pessoal Civil SIPEC."

390 “Art. 21. Todos os direitos de exploração e produção de petróleo, de gás natural e de outros hidrocarbonetos fluidos em território nacional, nele compreendidos a parte terrestre, o mar territorial, a plataforma continental e a zona econômica exclusiva, pertencem à União, cabendo sua administração à ANP, ressalvadas as competências de outros órgãos e entidades expressamente estabelecidas em lei.”

391 “Art. 76. A ANP poderá contratar especialistas para a execução de trabalhos nas áreas técnica, econômica e jurídica, por projetos ou prazos limitados, com dispensa de licitação nos casos previstos na legislação aplicável."

392 "Art. 29. Fica criado, dentro do limite quantitativo do Quadro Efetivo da ANATEL, ANEEL, ANP e ANS, Quadro de Pessoal Específico a que se refere o art. 19, composto por servidores que tenham sido redistribuídos para as Agências até a data da promulgação desta Lei."

393 "§ $2^{\circ} \mathrm{O}$ regime autárquico especial conferido à ANTT e à ANTAQ é caracterizado pela independência administrativa, autonomia financeira e funcional e mandato fixo de seus dirigentes."

394 “Art. 54. Os membros da Diretoria cumprirão mandatos de quatro anos, não coincidentes, admitida uma recondução."

395 “Art. 56. Os membros da Diretoria perderão o mandato em virtude de renúncia, condenação judicial transitada em julgado, processo administrativo disciplinar, ou descumprimento manifesto de suas atribuições."

396 “Art. 57. Aos membros das Diretorias das Agências é vedado o exercício de qualquer outra atividade profissional, empresarial, sindical ou de direção político-partidária."

397 “Art. 58. Está impedida de exercer cargo de direção na ANTT e na ANTAQ a pessoa que mantenha, ou tenha mantido, nos doze meses anteriores à data de início do mandato, um dos seguintes vínculos com empresa que explore qualquer das atividades reguladas pela respectiva Agência: I - participação direta como acionista ou sócio; II - administrador, gerente ou membro do Conselho Fiscal; III - empregado, ainda que com contrato de trabalho suspenso, inclusive de sua instituição controladora, ou de fundação de previdência de que a empresa ou sua controladora seja patrocinadora ou custeadora." 
4.3. Autonomia financeira: arts. $21, \S 2^{\circ}, 24, \mathrm{XV}^{399}$, da Lei $\mathrm{n}^{\mathrm{o}} 10.233 / 2001,22^{400} \mathrm{da}$ Lei $n^{\circ} 9.986 / 2000$.

4.4. Autonomia de gestão: arts. $21, \S 2^{\circ}, 25$, VI, VII ${ }^{401}, 122^{402}$ da Lei $n^{\circ} 10.233 / 2001$, $31^{403}$ da Lei $n^{\circ} 9.986 / 2000$.

4.5. Prerrogativa de organização de seus serviços: art. 61 da Lei no 10.233/2001.

4.6. Regime de pessoal específico: arts. $70^{404}, 72^{405}, 113^{406}, 113-\mathrm{A}^{407}, 122$ da Lei $\mathrm{n}^{\mathrm{o}}$ $10.233 / 2001,2^{\mathrm{o}^{408}}, 14^{409}, 19, \S \S 3^{\mathrm{o}}$ e $4^{\mathrm{u}^{410}}$, da Lei $\mathrm{n}^{\mathrm{o}} 9.986 / 2000$.

398 “Art. 61. Cabe ao Diretor-Geral a representação da Agência e o comando hierárquico sobre pessoal e serviços, exercendo a coordenação das competências administrativas, bem como a presidência das reuniões da Diretoria."

399 “Art. 24. Cabe à ANTT, em sua esfera de atuação, como atribuições gerais: XV - elaborar o seu orçamento e proceder à respectiva execução financeira."

400 "Art. 22. Ficam as Agências autorizadas a custear as despesas com remoção e estada para os profissionais que, em virtude de nomeação para Cargos Comissionados de Direção, de Gerência Executiva e de Assessoria dos níveis CD I e II, CGE I, II, III e IV, CA I e II, e para os Cargos Comissionados Técnicos, nos níveis CCT V e IV, vierem a ter exercício em cidade diferente da de seu domicílio, conforme disposto em regulamento de cada Agência, observados os limites de valores estabelecidos para a Administração Pública Federal direta."

401 "VI - articular-se com órgãos e instituições dos Estados, do Distrito Federal e dos Municípios para conciliação do uso da via permanente sob sua jurisdição com as redes locais de metrôs e trens urbanos destinados ao deslocamento de passageiros; VII - contribuir para a preservação do patrimônio histórico e da memória das ferrovias, em cooperação com as instituições associadas à cultura nacional, orientando e estimulando a participação dos concessionários do setor."

402 “Art. 122. A ANTT, a ANTAQ e o DNIT poderão contratar especialistas ou empresas especializadas, inclusive consultores independentes e auditores externos, para execução de trabalhos técnicos, por projetos ou por prazos determinados, nos termos da legislação em vigor."

403 “Art. 31. As Agências Reguladoras, no exercício de sua autonomia, poderão desenvolver sistemas próprios de administração de recursos humanos, inclusive cadastro e pagamento, sendo obrigatória a alimentação dos sistemas de informações mantidos pelo órgão central do Sistema de Pessoal Civil SIPEC."

404 “Art. 70. Para constituir os quadros de pessoal efetivo e de cargos comissionados da ANTT e da ANTAQ, ficam criados: III - os cargos efetivos de nível superior de Procurador; IV - os Cargos Comissionados de Direção - CD, de Gerência Executiva - CGE, de Assessoria - CA e de Assistência - CAS; V - os Cargos Comissionados Técnicos - CCT."

405 “Art. 72. Os Cargos Comissionados de Gerência Executiva, de Assessoria e de Assistência são de livre nomeação e exoneração da Diretoria da Agência."

406 “Art. 113. Ficam criados os quadros de Pessoal Específico na ANTT, na ANTAQ e no DNIT, com a finalidade de absorver servidores do Regime Jurídico Único, dos quadros de pessoal do Departamento Nacional de Estradas de Rodagem - DNER e do Ministério dos Transportes."

407 “Art. 113-A O ingresso nos cargos de que trata o art. 113 será feito por redistribuição do cargo, na forma do disposto na Lei $\mathrm{n}^{\circ} 9.986$, de 18 de julho de 2000."

408 “Art. 2o Ficam criados, para exercício exclusivo nas Agências Reguladoras, os cargos Comissionados de Direção - CD, de Gerência Executiva - CGE, de Assessoria - CA e de Assistência - CAS, e os Cargos Comissionados Técnicos - CCT, constantes do Anexo I desta Lei."

409 “Art. 14. Os quantitativos dos empregos públicos e dos cargos comissionados de cada Agência serão estabelecidos em lei, ficando as Agências autorizadas a efetuar a alteração dos quantitativos e da distribuição dos Cargos Comissionados de Gerência Executiva, de Assessoria, de Assistência e dos Cargos Comissionados Técnicos, observados os valores de retribuição correspondentes e desde que não acarrete aumento de despesa."

410 “Art. 19. Mediante lei, poderão ser criados Quadro de Pessoal Específico, destinado, exclusivamente, à absorção de servidores públicos federais regidos pela Lei no 8.112, de 11 de dezembro de 1990, e Quadro de Pessoal em Extinção, destinado exclusivamente à absorção de empregados de empresas públicas federais liquidadas ou em processo de liquidação, regidos pelo regime celetista, que se encontrarem exercendo atividades a serem absorvidas pelas Agências. $\S 3^{\circ}$ À medida que forem extintos os cargos ou 


\section{ANTAQ:}

Dispositivos normativos referentes a:

5.1. Estabilidade dos dirigentes e "quarentena": art. $21, \S 2^{\circ}, 54,56,57,58$ da Lei $n^{\circ}$ $10.233 / 2001$.

5.2. Ausência de controle hierárquico: art. 61 da Lei $n^{\circ} 10.233 / 2001$.

5.3. Autonomia financeira: arts. 21, $\S 2^{\circ}, 24, \mathrm{XV}, 27, \mathrm{XX}^{411}$, da Lei $\mathrm{n}^{\mathrm{o}} 10.233 / 2001,22$ da Lei $n^{\circ}$ 9.986/2000.

5.4. Autonomia de gestão: arts. $21, \S 2^{\circ}, 122$ da Lei $n^{\circ} 10.233 / 2001,31$ da Lei $n^{\circ}$ 9.986/2000.

5.5. Prerrogativa de organização de seus serviços: art. 61 da Lei $n^{0} 10.233 / 2001$.

5.6. Regime de pessoal específico: arts. 70, 72, 113, 113-A e 122 da Lei $\mathrm{n}^{\mathrm{o}}$ $10.233 / 2001,2^{\circ}, 14,19, \S \S 3^{\circ}$ e $4^{\text {o }}$, da Lei no $9.986 / 2000$.

\section{ANAC:}

Dispositivos normativos referentes a:

6.1. Estabilidade dos dirigentes e “quarentena": arts. $4^{0412}, 12^{413}, 13, \S 1^{0414}, 14$, caput $^{415}$, da Lei $\mathrm{n}^{\mathrm{o}} 11.182 / 2005$.

6.2. Ausência de controle hierárquico: arts. $4^{\circ}, 16^{416}$ da Lei $n^{\circ} 11.182 / 2005$.

empregos dos Quadros de que trata este artigo, é facultado à Agência o preenchimento de empregos de pessoal concursado para o Quadro de Pessoal Efetivo. $\S 4^{\circ}$ Se o quantitativo de cargos ou empregos dos Quadros de que trata este artigo for inferior ao Quadro de Pessoal Efetivo, é facultada à Agência a realização de concurso para preenchimento dos empregos excedentes."

411 “Art. 27. Cabe à ANTAQ, em sua esfera de atuação: XX - elaborar o seu orçamento e proceder à respectiva execução financeira."

412 "Art. 4 ${ }^{\circ}$ A natureza de autarquia especial conferida à ANAC é caracterizada por independência administrativa, autonomia financeira, ausência de subordinação hierárquica e mandato fixo de seus dirigentes."

413 “Art. 12. Os diretores serão brasileiros, de reputação ilibada, formação universitária e elevado conceito no campo de especialidade dos cargos para os quais serão nomeados pelo Presidente da República, após serem aprovados pelo Senado Federal, nos termos da alínea f do inciso III do art. 52 da Constituição Federal."

414 “Art. 13. O mandato dos diretores será de 5 (cinco) anos. $§ 1^{\circ}$ Os mandatos dos 1 os (primeiros) membros da Diretoria serão, respectivamente, 1 (um) diretor por 3 (três) anos, 2 (dois) diretores por 4 (quatro) anos e 2 (dois) diretores por 5 (cinco) anos, a serem estabelecidos no decreto de nomeação."

415 “Art. 14. Os diretores somente perderão o mandato em virtude de renúncia, de condenação judicial transitada em julgado, ou de pena demissória decorrente de processo administrativo disciplinar."

416 “Art. 16. Cabe ao Diretor-Presidente a representação da ANAC, o comando hierárquico sobre o pessoal e o serviço, exercendo todas as competências administrativas correspondentes, bem como a presidência das reuniões da Diretoria." 
6.3. Autonomia financeira: arts. $4^{\circ}, 8^{\circ}, \mathrm{XXXVI}^{417}, 33^{418}, 50^{419}$ da Lei $\mathrm{n}^{\mathrm{o}} 11.182 / 2005$, $22^{420}$ da Lei $n^{\circ} 9.986 / 2000$.

6.4. Autonomia de gestão: arts. $4^{\mathrm{o}}, 8^{\mathrm{o}}, \mathrm{XXXVIII}^{421}, 16^{422}, 37^{423}, 43^{424}$ da Lei $\mathrm{n}^{\mathrm{o}}$ $11.182 / 2005,31^{425}$ da Lei ${ }^{\circ}$ 9.986/2000.

6.5. Prerrogativa de organização de seus serviços: art. $4^{\circ}, 39$, caput $^{426}, 43^{427}$ da Lei $\mathrm{n}^{\mathrm{o}}$ $11.182 / 2005$.

6.6. Regime de pessoal específico: arts. $8^{\circ}$, XXXVII, XLII ${ }^{428}, 21^{429}, 24^{430}, 25^{431}, 36$, caput $^{432}, 38-\mathrm{A}^{433}$ da Lei $\mathrm{n}^{\mathrm{o}} 11.182 / 2005,2^{\mathrm{o} 434}, 14^{435}, 19, \S \S 3^{\mathrm{o}}$ e $4^{\mathrm{o} 436}$, da Lei $\mathrm{n}^{\mathrm{o}}$ $9.986 / 2000$.

417 “Art. $8^{\circ}$ Cabe à ANAC adotar as medidas necessárias para o atendimento do interesse público e para o desenvolvimento e fomento da aviação civil, da infraestrutura aeronáutica e aeroportuária do País, atuando com independência, legalidade, impessoalidade e publicidade, competindo-lhe: XXXVI arrecadar, administrar e aplicar suas receitas."

418 “Art. 33. O Fundo Aeroviário, fundo de natureza contábil e de interesse da defesa nacional, criado pelo Decreto-Lei ${ }^{\circ}$ 270, de 28 de fevereiro de 1967, alterado pela Lei $n^{\circ}$ 5.989, de 17 de dezembro de 1973, incluídos seu saldo financeiro e seu patrimônio existentes nesta data, passa a ser administrado pela Agência Nacional de Aviação Civil."

419 “Art. 50. As despesas decorrentes da aplicação desta Lei correrão à conta do Orçamento da ANAC.

420 “Art. 22. Ficam as Agências autorizadas a custear as despesas com remoção e estada para os profissionais que, em virtude de nomeação para Cargos Comissionados de Direção, de Gerência Executiva e de Assessoria dos níveis CD I e II, CGE I, II, III e IV, CA I e II, e para os Cargos Comissionados Técnicos, nos níveis CCT V e IV, vierem a ter exercício em cidade diferente da de seu domicílio, conforme disposto em regulamento de cada Agência, observados os limites de valores estabelecidos para a Administração Pública Federal direta."

421 “Art. $8^{\circ}$ Cabe à ANAC adotar as medidas necessárias para o atendimento do interesse público e para o desenvolvimento e fomento da aviação civil, da infraestrutura aeronáutica e aeroportuária do País, atuando com independência, legalidade, impessoalidade e publicidade, competindo-lhe: XXXVIII adquirir, administrar e alienar seus bens."

422 “Art. 16. Cabe ao Diretor-Presidente a representação da ANAC, o comando hierárquico sobre o pessoal e o serviço, exercendo todas as competências administrativas correspondentes, bem como a presidência das reuniões da Diretoria."

423 “Art. 37. A ANAC poderá requisitar, com ônus, servidores e empregados de órgãos e entidades integrantes da Administração Pública."

424 “Art. 43. Aprovado seu regulamento, a ANAC passará a ter o controle sobre todas as atividades, contratos de concessão e permissão, e autorizações de serviços aéreos, celebrados por órgãos ou entidades da Administração direta ou indireta da União.

425 “Art. 31. As Agências Reguladoras, no exercício de sua autonomia, poderão desenvolver sistemas próprios de administração de recursos humanos, inclusive cadastro e pagamento, sendo obrigatória a alimentação dos sistemas de informações mantidos pelo órgão central do Sistema de Pessoal Civil SIPEC."

426 "Art. 39. Nos termos do inciso IX do art. 37 da Constituição Federal, fica a ANAC autorizada a efetuar a contratação temporária do pessoal imprescindível à implantação de suas atividades, por prazo não excedente a 36 (trinta e seis) meses, a contar de sua instalação."

427 “Art. 43. Aprovado seu regulamento, a ANAC passará a ter o controle sobre todas as atividades, contratos de concessão e permissão, e autorizações de serviços aéreos, celebrados por órgãos ou entidades da Administração direta ou indireta da União."

428 “Art. $8^{\circ}$ Cabe à ANAC adotar as medidas necessárias para o atendimento do interesse público e para o desenvolvimento e fomento da aviação civil, da infraestrutura aeronáutica e aeroportuária do País, atuando com independência, legalidade, impessoalidade e publicidade, competindo-lhe: XXXVII contratar pessoal por prazo determinado, de acordo com a legislação aplicável; XLII - administrar os cargos efetivos, os cargos comissionados e as gratificações de que trata esta Lei." 
429 “Art. 21. Ficam criados, para exercício exclusivo na ANAC, os Cargos Comissionados de Direção - CD, de Gerência Executiva - CGE, de Assessoria - CA e de Assistência - CAS, e os Cargos Comissionados Técnicos - CCT, nos quantitativos constantes da Tabela B do Anexo I desta Lei."

430 “Art. 24. Na estrutura dos cargos da ANAC, o provimento por um servidor civil, de Cargo Comissionado de Gerência Executiva, de Assessoria, de Assistência e de Técnico, implicará o bloqueio, para um militar, da concessão de uma correspondente Gratificação de Exercício em Cargo de Confiança e de Gratificação de Representação pelo Exercício de Função, e vice-versa."

431 “Art. 25. Os Cargos Comissionados Técnicos são de ocupação privativa de servidores e empregados do Quadro de Pessoal Efetivo, do Quadro de Pessoal Específico e de requisitados de outros órgãos e entidades da Administração Pública."

432 “Art. 36. Fica criado o Quadro de Pessoal Específico, integrado por servidores regidos pela Lei n ${ }^{\circ} 8.112$, de 11 de dezembro de 1990."

433 “Art. 38-A. O quantitativo de servidores ocupantes dos cargos do Quadro de Pessoal Específico, acrescido dos servidores ou empregados requisitados, não poderá exceder o número de cargos efetivos."

434 “Art. $2^{\circ}$ Ficam criados, para exercício exclusivo nas Agências Reguladoras, os cargos Comissionados de Direção - CD, de Gerência Executiva - CGE, de Assessoria - CA e de Assistência - CAS, e os Cargos Comissionados Técnicos - CCT, constantes do Anexo I desta Lei."

435 “Art. 14. Os quantitativos dos empregos públicos e dos cargos comissionados de cada Agência serão estabelecidos em lei, ficando as Agências autorizadas a efetuar a alteração dos quantitativos e da distribuição dos Cargos Comissionados de Gerência Executiva, de Assessoria, de Assistência e dos Cargos Comissionados Técnicos, observados os valores de retribuição correspondentes e desde que não acarrete aumento de despesa."

436 “Art. 19. Mediante lei, poderão ser criados Quadro de Pessoal Específico, destinado, exclusivamente, à absorção de servidores públicos federais regidos pela Lei no 8.112, de 11 de dezembro de 1990, e Quadro de Pessoal em Extinção, destinado exclusivamente à absorção de empregados de empresas públicas federais liquidadas ou em processo de liquidação, regidos pelo regime celetista, que se encontrarem exercendo atividades a serem absorvidas pelas Agências.

$\S 3^{\circ}$ À medida que forem extintos os cargos ou empregos dos Quadros de que trata este artigo, é facultado à Agência o preenchimento de empregos de pessoal concursado para o Quadro de Pessoal Efetivo.

$\S 4^{\circ} \mathrm{Se}$ o quantitativo de cargos ou empregos dos Quadros de que trata este artigo for inferior ao Quadro de Pessoal Efetivo, é facultada à Agência a realização de concurso para preenchimento dos empregos excedentes." 



\section{APÊNDICE C - UNIVERSO DE ACÓRDÃOS ANALISADOS}

Quadro 1 - Universo de acórdãos analisados (continua).

\begin{tabular}{|c|c|c|c|c|c|c|c|c|c|c|}
\hline Item & Acórdão & $\begin{array}{l}\text { Data da } \\
\text { sessão }\end{array}$ & Relator & Subtema & Tipo do processo & Agência & $\begin{array}{c}\text { Emissão de } \\
\text { comando } \\
\text { relacionado à } \\
\text { função reguladora }\end{array}$ & $\begin{array}{c}\text { A análise da unidade } \\
\text { técnica instrutiva foi } \\
\text { acolhida pelo Relator e } \\
\text { pelo Plenário? }\end{array}$ & Enquadramento & Resultado do controle \\
\hline 1 & $\begin{array}{l}\text { 1089/2016 } \\
\text { - Plenário }\end{array}$ & $04 / 05 / 2016$ & $\begin{array}{l}\text { Bruno } \\
\text { Dantas }\end{array}$ & Abrangência & $\begin{array}{l}\text { Solicitação do } \\
\text { congresso nacional }\end{array}$ & Anatel & Não & Sim & $\begin{array}{c}\text { Função } \\
\text { fiscalizadora; } \\
\text { Função } \\
\text { adjudicatória }\end{array}$ & $\begin{array}{l}\text { Ausência de } \\
\text { reverberação na função } \\
\text { reguladora }\end{array}$ \\
\hline 2 & $\begin{array}{l}\text { 943/2016 - } \\
\text { Plenário }\end{array}$ & $20 / 04 / 2016$ & $\begin{array}{l}\text { Augusto } \\
\text { Nardes }\end{array}$ & Pedágio & $\begin{array}{l}\text { Desestatização. } \\
\text { Acompanhamento }\end{array}$ & ANTT & Sim & Sim & $\begin{array}{c}\text { Função } \\
\text { adjudicatória }\end{array}$ & $\begin{array}{l}\text { Determinação e } \\
\text { recomendação }\end{array}$ \\
\hline 3 & $\begin{array}{l}\text { 644/2016 - } \\
\text { Plenário }\end{array}$ & $23 / 03 / 2016$ & $\begin{array}{c}\text { Walton } \\
\text { Alencar } \\
\text { Rodrigues }\end{array}$ & Abrangência & Desestatização & Aneel & Sim & Sim & $\begin{array}{c}\text { Função } \\
\text { adjudicatória }\end{array}$ & Determinação \\
\hline 4 & $\begin{array}{l}\text { 2071/2015 } \\
\text { - Plenário }\end{array}$ & $19 / 08 / 2015$ & $\begin{array}{l}\text { Vital do } \\
\text { Rêgo }\end{array}$ & Abrangência & Relatório de auditoria & Aneel & Sim & Sim & $\begin{array}{l}\text { Função } \\
\text { fiscalizadora; } \\
\text { Função } \\
\text { normativa }\end{array}$ & Determinação \\
\hline 5 & $\begin{array}{l}\text { 909/2015 - } \\
\text { Plenário }\end{array}$ & $22 / 04 / 2015$ & $\begin{array}{l}\text { Vital do } \\
\text { Rêgo }\end{array}$ & Abrangência & $\begin{array}{c}\text { Solicitação do } \\
\text { congresso nacional }\end{array}$ & Aneel & Não & Sim & $\begin{array}{c}\text { Função } \\
\text { adjudicatória }\end{array}$ & $\begin{array}{l}\text { Solicitação de envio de } \\
\text { informação }\end{array}$ \\
\hline 6 & $\begin{array}{l}\text { 2314/2014 } \\
\text { - Plenário }\end{array}$ & $03 / 09 / 2014$ & José Jorge & Abrangência & $\begin{array}{c}\text { Solicitação do } \\
\text { congresso nacional }\end{array}$ & Aneel & Não & Sim & $\begin{array}{l}\text { Função } \\
\text { fiscalizadora }\end{array}$ & $\begin{array}{l}\text { Solicitação de envio de } \\
\text { informação }\end{array}$ \\
\hline 7 & $\begin{array}{l}\text { 2241/2013 } \\
\text { - Plenário }\end{array}$ & $21 / 08 / 2013$ & $\begin{array}{c}\text { José } \\
\text { Múcio } \\
\text { Monteiro }\end{array}$ & Abrangência & Acompanhamento & Antaq & Não & Parcialmente & $\begin{array}{l}\text { Função } \\
\text { fiscalizadora }\end{array}$ & $\begin{array}{l}\text { Solicitação de envio de } \\
\text { informação }\end{array}$ \\
\hline
\end{tabular}


Quadro 1 - Universo de acórdãos analisados (continuação).

\begin{tabular}{|c|c|c|c|c|c|c|c|c|c|c|}
\hline Item & Acórdão & $\begin{array}{l}\text { Data da } \\
\text { sessão }\end{array}$ & Relator & Subtema & Tipo do processo & Agência & $\begin{array}{c}\text { Emissão de } \\
\text { comando } \\
\text { relacionado à } \\
\text { função reguladora }\end{array}$ & $\begin{array}{c}\text { A análise da unidade } \\
\text { técnica instrutiva foi } \\
\text { acolhida pelo Relator e } \\
\text { pelo Plenário? }\end{array}$ & Enquadramento & Resultado do controle \\
\hline 8 & $\begin{array}{l}\text { 402/2013 - } \\
\text { Plenário }\end{array}$ & $06 / 03 / 2013$ & $\begin{array}{l}\text { Raimundo } \\
\text { Carreiro }\end{array}$ & Abrangência & Representação & Antaq & Não & Não & $\begin{array}{l}\text { Função } \\
\text { fiscalizadora; } \\
\text { Função } \\
\text { normativa }\end{array}$ & $\begin{array}{l}\text { Ausência de } \\
\text { reverberação na função } \\
\text { reguladora }\end{array}$ \\
\hline 9 & $\begin{array}{l}\text { 210/2013 - } \\
\text { Plenário }\end{array}$ & $20 / 02 / 2013$ & José Jorge & Abrangência & $\begin{array}{l}\text { Solicitação do } \\
\text { congresso nacional }\end{array}$ & Anatel & Sim & Parcialmente & $\begin{array}{l}\text { Função } \\
\text { fiscalizadora; } \\
\text { Função } \\
\text { normativa }\end{array}$ & Recomendação \\
\hline 10 & $\begin{array}{l}\text { 2302/2012 } \\
\text { - Plenário }\end{array}$ & $29 / 08 / 2012$ & $\begin{array}{l}\text { Raimundo } \\
\text { Carreiro }\end{array}$ & Abrangência & Representação & ANTT & Não & $\begin{array}{l}\text { Pelo relator, não. Pelo } \\
\text { plenário, sim. }\end{array}$ & $\begin{array}{c}\text { Função } \\
\text { adjudicatória }\end{array}$ & $\begin{array}{l}\text { Ausência de } \\
\text { reverberação na função } \\
\text { reguladora }\end{array}$ \\
\hline 11 & $\begin{array}{l}3234 / 2011 \\
\text { - Plenário }\end{array}$ & 07/12/2011 & $\begin{array}{l}\text { Aroldo } \\
\text { Cedraz }\end{array}$ & $\begin{array}{l}\text { Revisão } \\
\text { tarifária }\end{array}$ & Desestatização & Anac & Sim & $\operatorname{Sim}$ & $\begin{array}{c}\text { Função } \\
\text { adjudicatória }\end{array}$ & $\begin{array}{l}\text { Determinação e } \\
\text { recomendação }\end{array}$ \\
\hline 12 & $\begin{array}{l}\text { 3233/2011 } \\
\text { - Plenário }\end{array}$ & 07/12/2011 & $\begin{array}{l}\text { Aroldo } \\
\text { Cedraz }\end{array}$ & $\begin{array}{l}\text { Revisão } \\
\text { tarifária }\end{array}$ & Desestatização & Anac & Sim & $\operatorname{Sim}$ & $\begin{array}{c}\text { Função } \\
\text { adjudicatória }\end{array}$ & $\begin{array}{l}\text { Determinação e } \\
\text { recomendação }\end{array}$ \\
\hline 13 & $\begin{array}{l}3232 / 2011 \\
\text { - Plenário }\end{array}$ & $07 / 12 / 2011$ & $\begin{array}{l}\text { Aroldo } \\
\text { Cedraz }\end{array}$ & $\begin{array}{l}\text { Revisão } \\
\text { tarifária }\end{array}$ & Desestatização & Anac & Sim & $\operatorname{Sim}$ & $\begin{array}{c}\text { Função } \\
\text { adjudicatória }\end{array}$ & $\begin{array}{l}\text { Determinação e } \\
\text { recomendação }\end{array}$ \\
\hline 14 & $\begin{array}{l}\text { 683/2010 - } \\
\text { Plenário }\end{array}$ & 07/04/2010 & $\begin{array}{l}\text { Walton } \\
\text { Alencar } \\
\text { Rodrigues }\end{array}$ & Pedágio & Desestatização & ANTT & Sim & Sim & $\begin{array}{c}\text { Função } \\
\text { adjudicatória }\end{array}$ & $\begin{array}{l}\text { Determinação e } \\
\text { recomendação }\end{array}$ \\
\hline 15 & $\begin{array}{l}\text { 1904/2009 } \\
\text { - Plenário }\end{array}$ & $26 / 08 / 2009$ & $\begin{array}{l}\text { Walton } \\
\text { Alencar } \\
\text { Rodrigues }\end{array}$ & $\begin{array}{l}\text { Revisão } \\
\text { tarifária }\end{array}$ & $\begin{array}{l}\text { Relatório de } \\
\text { Auditoria }\end{array}$ & Antaq & Sim & Parcialmente & $\begin{array}{c}\text { Função } \\
\text { fiscalizadora; } \\
\text { Função } \\
\text { adjudicatória; } \\
\text { Função } \\
\text { normativa }\end{array}$ & Determinação \\
\hline
\end{tabular}

Quadro 1 - Universo de acórdãos analisados (continuação). 


\begin{tabular}{|c|c|c|c|c|c|c|c|c|c|c|}
\hline Item & Acórdão & $\begin{array}{l}\text { Data da } \\
\text { sessão }\end{array}$ & Relator & Subtema & Tipo do processo & Agência & $\begin{array}{c}\text { Emissão de } \\
\text { comando } \\
\text { relacionado à } \\
\text { função reguladora }\end{array}$ & $\begin{array}{l}\text { A análise da unidade } \\
\text { técnica instrutiva foi } \\
\text { acolhida pelo Relator e } \\
\text { pelo Plenário? }\end{array}$ & Enquadramento & Resultado do controle \\
\hline 16 & $\begin{array}{l}\text { 1201/2009 } \\
\text { - Plenário }\end{array}$ & 03/06/2009 & $\begin{array}{l}\text { Aroldo } \\
\text { Cedraz }\end{array}$ & Abrangência & Representação & Aneel & Não & Sim & $\begin{array}{l}\text { Função } \\
\text { adjudicatória; } \\
\text { Função } \\
\text { normativa }\end{array}$ & $\begin{array}{l}\text { Ausência de } \\
\text { reverberação na função } \\
\text { reguladora }\end{array}$ \\
\hline 17 & $\begin{array}{l}\text { 715/2008 - } \\
\text { Plenário }\end{array}$ & $23 / 04 / 2008$ & $\begin{array}{l}\text { Augusto } \\
\text { Nardes }\end{array}$ & Abrangência & Representação & ANTT & Não & Parcialmente & $\begin{array}{c}\text { Função } \\
\text { adjudicatória }\end{array}$ & Recomendação \\
\hline 18 & $\begin{array}{l}\text { 620/2008 - } \\
\text { Plenário }\end{array}$ & $11 / 03 / 2008$ & $\begin{array}{l}\text { Benjamin } \\
\text { Zymler }\end{array}$ & Abrangência & Denúncia & Aneel & Não & Não & $\begin{array}{l}\text { Função } \\
\text { fiscalizadora }\end{array}$ & $\begin{array}{l}\text { Ausência de } \\
\text { reverberação na função } \\
\text { reguladora }\end{array}$ \\
\hline 19 & $\begin{array}{l}\text { 602/2008 - } \\
\text { Plenário }\end{array}$ & $11 / 03 / 2008$ & $\begin{array}{l}\text { Benjamin } \\
\text { Zymler }\end{array}$ & Abrangência & Acompanhamento & Aneel & Sim & Parcialmente & $\begin{array}{c}\text { Função } \\
\text { adjudicatória }\end{array}$ & Recomendação \\
\hline 20 & $\begin{array}{l}\text { 2138/2007 } \\
\text { - Plenário }\end{array}$ & $10 / 10 / 2007$ & $\begin{array}{c}\text { Benjamin } \\
\text { Zymler }\end{array}$ & Abrangência & Acompanhamento & Aneel & Sim & Parcialmente & $\begin{array}{c}\text { Função } \\
\text { adjudicatória }\end{array}$ & Recomendação \\
\hline 21 & $\begin{array}{l}\text { 632/2007 - } \\
\text { Plenário }\end{array}$ & $18 / 04 / 2007$ & $\begin{array}{l}\text { Augusto } \\
\text { Nardes }\end{array}$ & Abrangência & $\begin{array}{l}\text { Solicitação do } \\
\text { congresso nacional }\end{array}$ & Antaq & Sim & $\operatorname{Sim}$ & $\begin{array}{l}\text { Função } \\
\text { fiscalizadora; } \\
\text { Função } \\
\text { adjudicatória }\end{array}$ & Determinação \\
\hline 22 & $\begin{array}{l}\text { 200/2007 - } \\
\text { Plenário }\end{array}$ & $28 / 02 / 2007$ & $\begin{array}{l}\text { Valmir } \\
\text { Campelo }\end{array}$ & Abrangência & Desestatização & Aneel & $\operatorname{Sim}$ & Não & $\begin{array}{l}\text { Função } \\
\text { adjudicatória; } \\
\text { Função } \\
\text { normativa }\end{array}$ & $\begin{array}{l}\text { Determinação e } \\
\text { recomendação }\end{array}$ \\
\hline 23 & $\begin{array}{l}\text { 1369/2006 } \\
\text { - Plenário }\end{array}$ & 09/08/2006 & $\begin{array}{l}\text { Valmir } \\
\text { Campelo }\end{array}$ & Abrangência & $\begin{array}{l}\text { Relatório de } \\
\text { Auditoria }\end{array}$ & ANTT & Sim & Parcialmente & $\begin{array}{l}\text { Função } \\
\text { fiscalizadora; } \\
\text { Função } \\
\text { normativa }\end{array}$ & $\begin{array}{l}\text { Determinação e } \\
\text { recomendação }\end{array}$ \\
\hline
\end{tabular}


Quadro 1 - Universo de acórdãos analisados (conclusão).

\begin{tabular}{|c|c|c|c|c|c|c|c|c|c|c|}
\hline Item & Acórdão & $\begin{array}{l}\text { Data da } \\
\text { sessão }\end{array}$ & Relator & Subtema & Tipo do processo & Agência & $\begin{array}{c}\text { Emissão de } \\
\text { comando } \\
\text { relacionado à } \\
\text { função reguladora }\end{array}$ & $\begin{array}{l}\text { A análise da unidade } \\
\text { técnica instrutiva foi } \\
\text { acolhida pelo Relator e } \\
\text { pelo Plenário? }\end{array}$ & Enquadramento & Resultado do controle \\
\hline 24 & $\begin{array}{l}\text { 649/2005 - } \\
\text { Plenário }\end{array}$ & $25 / 05 / 2005$ & $\begin{array}{c}\text { Walton } \\
\text { Alencar } \\
\text { Rodrigues }\end{array}$ & $\begin{array}{l}\text { Revisão } \\
\text { tarifária }\end{array}$ & Desestatização & Aneel & Sim & Parcialmente & $\begin{array}{c}\text { Função } \\
\text { adjudicatória; } \\
\text { Função } \\
\text { normativa }\end{array}$ & $\begin{array}{l}\text { Determinação e } \\
\text { recomendação }\end{array}$ \\
\hline 25 & $\begin{array}{l}\text { 1926/2004 } \\
\text { - Plenário }\end{array}$ & $01 / 12 / 2004$ & $\begin{array}{l}\text { Adylson } \\
\text { Motta }\end{array}$ & $\begin{array}{l}\text { Revisão } \\
\text { tarifária }\end{array}$ & $\begin{array}{l}\text { Relatório De } \\
\text { Auditoria }\end{array}$ & Aneel & Sim & Sim & $\begin{array}{c}\text { Função } \\
\text { adjudicatória; } \\
\text { Função } \\
\text { normativa }\end{array}$ & $\begin{array}{l}\text { Determinação e } \\
\text { recomendação }\end{array}$ \\
\hline 26 & $\begin{array}{l}\text { 1757/2004 } \\
\text { - Plenário }\end{array}$ & $10 / 11 / 2004$ & $\begin{array}{l}\text { Benjamin } \\
\text { Zymler }\end{array}$ & Abrangência & Desestatização & Aneel & Sim & Não & $\begin{array}{l}\text { Função } \\
\text { adjudicatória; } \\
\text { Função } \\
\text { normativa }\end{array}$ & Recomendação \\
\hline 27 & $\begin{array}{l}\text { 1756/2004 } \\
\text { - Plenário }\end{array}$ & $10 / 11 / 2004$ & $\begin{array}{l}\text { Benjamin } \\
\text { Zymler }\end{array}$ & Abrangência & Desestatização & Aneel & Sim & $\begin{array}{l}\text { Pelo Relator, sim. Pelo } \\
\text { Plenário, não. }\end{array}$ & $\begin{array}{l}\text { Função } \\
\text { adjudicatória; } \\
\text { Função } \\
\text { normativa }\end{array}$ & Recomendação \\
\hline 28 & $\begin{array}{l}\text { 1703/2004 } \\
\text { - Plenário }\end{array}$ & $03 / 11 / 2004$ & $\begin{array}{l}\text { Benjamin } \\
\text { Zymler }\end{array}$ & Abrangência & $\begin{array}{l}\text { Relatório de } \\
\text { Auditoria }\end{array}$ & ANTT & Sim & Parcialmente & $\begin{array}{c}\text { Função } \\
\text { adjudicatória }\end{array}$ & $\begin{array}{l}\text { Determinação e } \\
\text { recomendação }\end{array}$ \\
\hline
\end{tabular}




\section{APÊNDICE D - SISTEMATIZAÇÃO DOS DADOS DO CONTROLE}

1) Acórdão 1.089/2016 - Plenário ..........................................................2212

2) Acórdão 943/2016 - Plenário.................................................................. 213

3) Acórdão 644/2016 - Plenário............................................................. 214

4) Acórdão 2.320/2015 - Plenário................................................................... 215

5) Acórdão 2.071/2015 - Plenário..........................................................2216

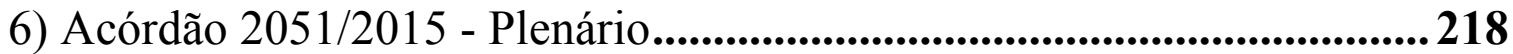

7) Acórdão 909/2015 - Plenário......................................................................... 219

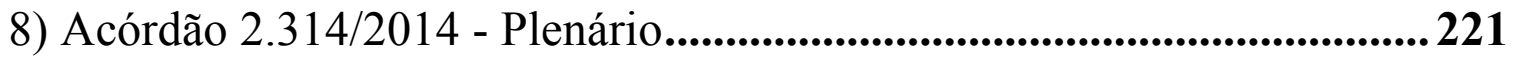

9) Acórdão 2.241/2013 - Plenário........................................................................ 222

10) Acórdão 569/2013 - Plenário.................................................................224

11) Acórdão 402/2013 - Plenário................................................................. 224

12) Acórdão 210/2013 - Plenário........................................................................ 226

13) Acórdão 2.302/2012 - Plenário................................................................... 227

14) Acórdão 3.234/2011 - Plenário....................................................................... 229

15) Acórdão 3.233/2011 - Plenário..........................................................2232

16) Acórdão 3.232/2011 - Plenário................................................................... 234

17) Acórdão 2.753/2011 - Plenário....................................................................... 238

18) Acórdão 683/2010 - Plenário.................................................................239

19) Acórdão 1.904/2009 - Plenário.............................................................240

20) Acórdão 1.201/2009 - Plenário............................................................... 242

21) Acórdão 1.131/2009 - Plenário..................................................................... 244

22) Acórdão 715/2008 - Plenário...................................................................... 245

23) Acórdão 620/2008 - Plenário....................................................................... 246

24) Acórdão 602/2008 - Plenário....................................................................... 248

25) Acórdão 2.138/2007 - Plenário................................................................250

26) Acórdão 632/2007 - Plenário....................................................................... 252

27) Acórdão 200/2007 - Plenário..................................................................... 253

28) Acórdão 1.369/2006 - Plenário...............................................................255

29) Acórdão 649/2005 - Plenário...................................................................... 256

30) Acórdão 1.926/2004 - Plenário.................................................................258

31) Acórdão 1.757/2004 - Plenário....................................................................260

32) Acórdão 1.756/2004 - Plenário................................................................261

33) Acórdão 1.703/2004 - Plenário........................................................263 


\section{1) ACóRDão 1.089/2016 - PlenÁRIO}

- Data da sessão: 04/05/2016.

- Relator: Bruno Dantas.

- Área: competência do Tribunal de Contas da União (TCU).

- Tema: agência reguladora.

- Subtema: abrangência.

- Tipo do processo: solicitação do Congresso Nacional encaminhada pelo presidente da Comissão de Meio Ambiente, Defesa do Consumidor e Fiscalização e Controle (CMA).

- Enunciado: "não compete ao TCU fiscalizar diretamente as empresas delegatárias de serviço público, mas sim examinar se o poder concedente está fiscalizando de forma adequada a execução dos contratos com elas celebrados".

- Objeto: requerimento de realização de auditoria com o objetivo de verificar a qualidade dos serviços de TV por assinatura e banda larga prestados no Brasil.

- Unidade técnica instrutiva: Secretaria de Fiscalização de Infraestrutura de Telecomunicações (SeinfraAeroTelecom).

- Agência: Agência Nacional de Telecomunicações (Anatel).

- Emissão de comando relacionado à função reguladora? Não.

- A análise da unidade técnica instrutiva (SeinfraAero Telecom) foi acolhida pelo relator e pelo Plenário? Sim.

- Precedente citado: Acórdão 210/2013.

- Fundamentos: arts. 70 e 71 da Constituição Federal de 1988.

- Enquadramento: análise das atribuições do TCU para controle da qualidade dos serviços concedidos (função fiscalizatória e adjudicatória).

- Resultado do controle: Ausência de reverberação na função reguladora Entendimento do acórdão: reconhecimento de que não compete ao TCU fiscalizar diretamente as empresas delegatárias de serviço público, mas sim examinar se o poder concedente está fiscalizando de forma adequada a execução dos contratos com elas celebrados. Neste processo em específico, deliberou-se que o Requerimento $\mathrm{n}^{\circ}$ 10/2015/CMA seria atendido por intermédio do encaminhamento dos documentos da auditoria operacional do TC 023.133/2015-5 e do acompanhamento objeto do TC 011.631/2016-3, cujos resultados seriam informados tão logo as fiscalizações fossem concluídas e apreciadas pelo Plenário do TCU. 


\section{2) ACÓRdão 943/2016 - Plenário}

- Data da sessão: 20/04/2016.

- Relator: Augusto Nardes.

- Área: desestatização.

- Tema: concessão pública.

- Subtema: pedágio.

- Outros indexadores: alíquota, Imposto Sobre Serviços de Qualquer Natureza (ISSQN), Programa de Exploração Rodoviária, reequilíbrio econômico-financeiro.

- Tipo do processo: desestatização, acompanhamento.

- Enunciado: "nas concessões rodoviárias, a agência reguladora deve definir, no Programa de Exploração da Rodovia (PER) e na minuta do contrato, cláusula estabelecendo que as alíquotas de ISSQN efetivamente praticadas pelos municípios limítrofes ao objeto da concessão deverão ser avaliadas previamente ao início da cobrança do pedágio e anualmente, daí em diante, efetuando os reequilíbrios contratuais cabíveis".

- Objeto: primeiro estágio do acompanhamento do processo de outorga de concessão da rodovia BR-364/365/GO/MG, nos trechos da BR-364 — entre a divisa MG/GO e o entroncamento com a BR-060 (Jataí) — e da BR-365 — entre o entroncamento com a LMG-749 (contorno oeste de Uberlândia) e o entroncamento com a BR-364 (divisa MG/GO) - integrantes do Programa de Investimentos em Logística (PIL).

- Agência: Agência Nacional de Transportes Terrestres (ANTT).

- Unidade técnica do TCU: Secretaria de Fiscalização da Infraestrutura Rodoviária (SeinfraRodovia).

- Emissão de comando relacionado à função reguladora? Sim.

- Fundamentos: art. 258, II, do Regimento Interno do TCU, combinado com o art. $3^{\circ}$, I, da Instrução Normativa TCU nº 46/2004 (dispõe sobre a fiscalização, pelo Tribunal de Contas da União, dos processos de concessão para exploração de rodovias federais, inclusive as rodovias ou os trechos rodoviários delegados pela União a estado, ao Distrito Federal, a município ou a consórcio entre eles); art. 43, I, da Lei $n^{\circ} 8.443$, de 16 de julho de 1992, c/c art. 250, II, do Regimento Interno do TCU (controle prévio à 
publicação do edital de concessão); art. 43, I, da Lei 8.443/1992, c/c art. 250, III ${ }^{437}$, do Regimento Interno do TCU; art. $4^{\circ}$ da Portaria-Segecex no 13/2011.

- A análise da unidade técnica instrutiva (SeinfraRodovia) foi acolhida pelo relator e pelo Plenário? Sim.

- Enquadramento: análise das atribuições do TCU para controle da qualidade dos serviços concedidos (função adjudicatória).

(i) Resultado do controle: determinações e recomendações.

- Entendimento do acórdão: determinações à ANTT de ordem técnica, obrigacionais (previsões editalícias e contratuais) referentes à qualidade dos serviços que serão prestados, bens reversíveis, penalidades, percentuais de atendimento do parâmetro de desempenho, reavaliação do Fator Q, previsão contratual sobre a contabilização do ISSQN pela concessionária, alterações nos estudos técnicos.

\section{3) Acórdão 644/2016 - Plenário}

- Data da sessão: 23/03/2016.

- Relator: Walton Alencar Rodrigues.

- Área: competência do TCU.

- Tema: agência reguladora.

- Subtema: abrangência.

- Outros indexadores: poder discricionário, economicidade, tarifa.

- Tipo do processo: Desestatização.

- Enunciado: “o TCU pode determinar medidas corretivas a ato praticado na esfera de discricionariedade das agências reguladoras, desde que esse ato viole o ordenamento jurídico, do qual fazem parte os princípios da economicidade da Administração Pública e da modicidade tarifária na prestação de serviços públicos”.

- Objeto: pedido de reexame interposto pela Agência Nacional de Energia Elétrica (Aneel) contra o Acórdão 1.293/2015-TCU-Plenário, que tratou de acompanhamento do primeiro estágio do Leilão Aneel $n^{0} 7 / 2015$, para concessão da prestação de serviço público de transmissão de energia elétrica, referente a construção, operação e

${ }^{437}$ Art. 250, III, do Regimento Interno do TCU: "recomendará a adoção de providências quando verificadas oportunidades de melhoria de desempenho, encaminhando os autos à unidade técnica competente, para fins de monitoramento do cumprimento das determinações;". 
manutenção de linha de transmissão, subestações e demais instalações associadas ao Bipolo-2 do Sistema de Transmissão da Usina Hidrelétrica Belo Monte/PA, a ser integrado à Rede Básica do Sistema Interligado Nacional. A Aneel considerou inadequada a determinação para utilizar o menor valor de cotação obtida para o módulo de equipamentos das estações conversoras, mesmo considerando tolerância de $20 \%$ no valor orçado, por acreditar que isso afastaria as melhores condições de concorrência nos leilões e prejudicaria a modicidade tarifária. Argumenta, ainda, que sua decisão em adotar o valor médio das cotações possuiria embasamento técnico suficiente e constituiria discricionariedade técnica da agência. No entendimento da recorrente, o cumprimento da determinação 9.2.1 do Acórdão 1.293/2015-TCU-Plenário prejudicaria o caráter competitivo do certame, causando a liquidação pelo teto estabelecido ou o esvaziamento do leilão.

- Agência: Aneel.

- Unidade técnica: Secretaria de Recursos (Serur); Secretaria de Fiscalização de Infraestrutura Elétrica (SeinfraElétrica).

- Emissão de comando relacionado à função reguladora? Sim.

- A análise da unidade técnica fiscalizadora foi acolhida pelo relator e pelo Plenário? Sim.

- Fundamento: arts. 32, 33 e 48 da Lei $n^{\circ} 8.443 / 1992$, c/c os arts. 285 e 286 do Regimento Interno do TCU, jurisprudência do TCU.

- Precedentes citados: Acórdãos n ${ }^{\text {os }} 1.201 / 2009,1.703 / 2004,556 / 2005,715 / 2008$, 1369/2006-Plenário, 1.703/2004-Plenário, 200/2007-Plenário, 602/2008-Plenário, 1.402/2010-Plenário e 2.241/2013-Plenário.

- Enquadramento: função adjudicatória.

(ii) Resultado do controle: manutenção das determinações do acórdão recorrido.

- Entendimento do acórdão: conhecer do pedido de reexame para, no mérito, negar-lhe provimento. O TCU pode determinar medidas corretivas a ato praticado na esfera de discricionariedade das agências reguladoras, desde que esse ato viole o ordenamento jurídico, do qual fazem partes os princípios da economicidade da administração pública e da modicidade tarifária na prestação de serviços públicos. 
- Data da sessão: 16/09/2015.

- Relator: Vital do Rêgo.

- Área: finanças públicas.

- Tema: Fundo de Fiscalização das Telecomunicações (Fistel).

- Subtema: desvinculação.

- Outros indexadores: recursos financeiros, erário, transferência de recursos.

- Tipo do processo: representação.

- Enunciado: "não há óbices à transferência (desvinculação) de recursos excedentes do Fistel — seja pelas disposições da lei de criação do Fundo (Lei n ${ }^{\circ}$ 5.070/1966), seja pela natureza dos tributos que o constituem - para o Tesouro Nacional, desde que garantida a operação normal da agência reguladora do setor (Anatel)"”.

- Objeto: pedido de reexame interposto pela Secretaria de Orçamento Federal (SOF/MP) contra o Acórdão 3.634/2013-TCU-Plenário, o qual determinou àquele órgão que: (i) apresentasse ao TCU um plano para a recomposição dos recursos do Fistel, utilizados indevidamente para a abertura de créditos adicionais nos exercícios de 2010 e de 2012 , destinados ao custeio de ações estranhas aos serviços de custeio, manutenção e aperfeiçoamento da fisscalização dos serviços de telecomunicações existentes no país; (ii) não utilizasse recursos de fontes vinculadas para a abertura de créditos adicionais não relacionados ao objeto da vinculação legal. Essa deliberação fundamentou-se na análise da Secretaria de Macroavaliação Governamental (Semag) do próprio TCU, acolhidas pelo relator e pelo Plenário, que consideraram ilegal a utilização de recursos do Fistel (fonte 78), nos exercícios de 2010 e 2012, para a abertura de créditos adicionais concedidos a órgãos dos três Poderes da União, por serem esses recursos destinados, em primeira análise, a despesas estranhas à finalidade legal do fundo.

- Agência: Anatel.

- Unidade técnica: Secretaria de Recursos (Serur).

- Emissão de comando relacionado à função reguladora? Não. O caso trata da utilização dos excedentes do Fistel (autonomia administrativa) e não se relaciona ao exercício direto da função reguladora, por isso foi excluído do universo final de análise.

\section{5) Acórdão 2.071/2015 - Plenário}


- Data da sessão: 19/08/2015.

- Relator: Vital do Rêgo.

- Área: competência do TCU.

- Tema: agência reguladora.

- Subtema: abrangência.

- Outros indexadores: fiscalização, atividade-fim.

- Tipo do processo: relatório de auditoria.

- Enunciado: "a atuação do controle externo nas atividades finalísticas das agências reguladoras limita-se à fiscalização de segunda ordem, respeitando os limites de atuação e a autonomia funcional daquelas entidades, não cabendo ao TCU avaliar, em casos concretos específicos, a correção das normas editadas por entidades regulatórias".

- Objeto: trata-se de pedido de reexame interposto pela empresa Centrais Elétricas Brasileiras S/A (Eletrobras) contra o Acórdão 336/2014-TCU-Plenário, que apreciou auditoria operacional destinada a avaliar os impactos sobre as tarifas de energia elétrica no Brasil em decorrência de políticas aplicáveis aos Sistemas Isolados, destacando-se a Conta de Consumo de Combustíveis Fósseis (CCC) e as perdas elétricas. Ademais, examinou-se o cumprimento, pela Eletrobras, de resoluções da Aneel atinentes à divulgação de informações sobre a CCC na internet.

- Agência: Aneel.

- Unidade técnica: Serur.

(iii) Emissão de comando relacionado à função reguladora? Sim, mas à Eletrobras empresa estatal regulada.

(iv) A análise da unidade técnica fiscalizadora foi acolhida pelo relator e pelo Plenário? Sim. A Serur, após examinar o feito, propôs que o recurso fosse conhecido e que, no mérito, negado provimento, aduzindo que

O art. 54 da Resolução-Aneel 457/2011 não constitui abuso do poder regulamentar, devendo a Eletrobras continuar a exercer seu papel de gerenciadora da CCC e divulgar, em sua página da internet, até o mês subsequente ao da ocorrência, todas as informações a respeito da $\mathrm{CCC}$, de modo a possibilitar o controle dos valores declarados.

O ministro relator seguiu a linha adotada pela unidade técnica, afirmando que 
cumpra dever expresso em regra cogente. Nessa toada, a irresignação da Eletrobras no presente caso não busca infirmar o teor da deliberação do TCU, mas sim impugnar a regulação da Aneel sobre o tema.

O Plenário referendou esse posicionamento.

- Fundamento normativo: arts. 43, I, e 48 da Lei no 8.443/1992; 250, II, e 279 do Regimento Interno; $3^{\circ}$ e 54 da Resolução Aneel no 427/2011; Lei n ${ }^{0}$ 8.631/1993; Decreto $n^{\circ} 774 / 1993$; Lei $n^{\circ} 12.111 / 2009$; e Decreto $n^{\circ} 7.426 / 2010$.

- Precedentes citados: Acórdãos 909/2015, 617/2015, 2.314/2014 e 210/2013 (todos do Plenário), no sentido de que a atuação do Tribunal de Contas da União no controle externo das atividades finalísticas das agências reguladoras cinge-se a uma fiscalização de segunda ordem, respeitando os limites de atuação e a autonomia funcional daquelas entidades.

(v)Enquadramento: função fiscalizadora e normativa (o TCU entendeu que a Aneel não usurpou de sua competência normativa na regulamentação da $\mathrm{CCC}$ e das responsabilidades da Eletrobras - recorrente —, exerceu função fiscalizadora).

- Resultado do controle/fiscalização: manutenção de comando de controle à Eletrobras.

- Entendimento do acórdão: o Tribunal de Contas da União conheceu do recurso, porém, no mérito, foi negado provimento, mantendo as determinações do Acórdão 336/2014TCU-Plenário.

\section{6) Acórdão 2051/2015 - Plenário}

- Data da sessão: 19/08/2015.

- Relator: Weder de Oliveira.

- Área: competência do TCU.

- Tema: agência reguladora.

- Subtema: abrangência.

- Outros indexadores: tribunal de contas estadual, concessão de serviço público, saneamento, estado-membro, município, tribunal de contas municipal.

- Tipo do processo: solicitação do Congresso Nacional.

- Enunciado: “compete às agências reguladoras estaduais ou municipais a regulação econômica dos contratos de concessão de serviços públicos de saneamento, bem como a 
apuração dos seus equilíbrios econômico-financeiros. Cabe aos tribunais de contas estaduais ou municipais o controle externo sobre esses contratos."

- Objeto: solicitação do Congresso Nacional, encaminhada por meio do Ofício $\mathrm{n}^{\mathrm{o}}$ 355/2014/CFFC-P, de 19/11/2014, da Comissão de Fiscalização Financeira e Controle da Câmara dos Deputados (PFC no 116/2013), com o objetivo de identificar o total de recursos federais que serão ou foram investidos em parcerias público-privadas (PPPs) de saneamento, bem como verificar se os respectivos contratos de concessão estão em conformidade com a Lei $\mathrm{n}^{\mathrm{o}} 11.445 / 2007$.

- Unidade técnica: Serur.

- Emissão de comando relacionado à função reguladora? Não, o Acórdão 2.051/2015 foi excluído do universo de análise por não se enquadrar nos critérios de seleção. O caso versava sobre solicitação do Congresso Nacional, encaminhada por meio do Ofício $\mathrm{n}^{\mathrm{o}}$ 355/2014/CFFC-P, de 19/11/2014, da Comissão de Fiscalização Financeira e Controle da Câmara dos Deputados (PFC no 116/2013), com o objetivo de identificar o total de recursos federais que seriam ou foram investidos em parcerias público-privadas (PPPs) de saneamento, e de verificar se os respectivos contratos de concessão estão em conformidade com a Lei $\mathrm{n}^{\mathrm{o}} 11.445 / 2007$. A despeito de abordar também tema afeto à regulação de serviço público, o acórdão foi excluído por não se enquadrar no recorte existência de agência reguladora federal para a regulação do serviço, inexistindo, assim, entidade sobre a qual recairia o exame da relação com o TCU. Vale, nesse sentido, citar entendimento presente no mencionado acórdão:

\footnotetext{
9.2.1. a regulação econômica dos contratos de concessões de serviços públicos de saneamento, inclusive a apuração do seus equilíbrios econômico-financeiros compete às agências reguladoras estaduais ou municipais, conforme o caso (como definiu o Supremo Tribunal Federal no julgamento da Adin 1.842-RJ, de $16 / 9 / 2013$ ), e o controle externo compete aos tribunais de contas estaduais ou municipais que lhes têm jurisdição. (TCU, Acórdão 2051/2015 - Plenário).
}

\section{7) Acórdão 909/2015 - Plenário}

- Data da sessão: 22/04/2015.

- Relator: Vital do Rêgo.

- Área: competência do TCU.

- Tema: agência reguladora. 
- Subtema: abrangência.

- Outros indexadores: qualidade, prestação de serviço, concessionária.

- Tipo do processo: solicitação do congresso nacional.

- Enunciado: "a fiscalização do cumprimento de metas de qualidade previstas nos contratos de concessão de serviços públicos não está abrangida na competência imediata do TCU. No exercício do controle externo da Administração Pública Federal, não compete ao tribunal fiscalizar diretamente as empresas delegatárias de serviço público, mas sim examinar se o poder concedente está fiscalizando, de forma adequada, a execução dos contratos celebrados. O controle exercido pelo TCU incide diretamente sobre a agência reguladora e mediatamente sobre as delegatárias".

- Objeto: solicitação do Congresso Nacional decorrente do Ofício P. 037/14/CTASP, de 21/5/2014 (Peça 1), subscrito pelo presidente da Comissão de Trabalho, Administração e Serviço Público da Câmara dos Deputados (CTASP), deputado Luiz Fernando Faria, que acolhe requerimento da lavra dos deputados Eduardo da Fonte e Roberto Teixeira. $\mathrm{Na}$ missiva, é requerida a realização de "auditoria no processo da Agência Nacional de Energia Elétrica (Aneel) que fixou a tarifa do serviço público de distribuição de energia elétrica no Estado de Pernambuco no ano de 2014", notadamente em face dos valores cobrados e da qualidade da prestação do serviço público de distribuição de energia elétrica. O caso é pertinente ao estudo porquanto presente entendimento de que a competência do TCU diante dos processos de reajuste anual das concessionárias de distribuição de energia elétrica alcança primordialmente o controle e a avaliação dos atos praticados pela Aneel na condução do processo (o que foi feito por intermédio dos Acórdãos 2.210/2008, 3.438/2012, 658/2013 e 3.182/2014 - Plenário).

- Agência: Aneel.

- Unidade técnica: SeinfraElétrica.

- Emissão de comando relacionado à função reguladora? Não.

- A análise da unidade técnica fiscalizadora foi acolhida pelo relator e pelo Plenário? Sim, "na essência".

- Fundamento normativo: art. 43, I, da Lei $n^{\circ}$ 8.443/1992, c/c o art. 250, II, do Regimento Interno do TCU.

- Precedentes citados: Acórdãos n ${ }^{\text {os }}$ 617/2015, 2.314/2014 e 210/2013, todos do Plenário.

- Enquadramento: autonomia administrativa, função adjudicatória.

- Resultado do controle: Solicitação de envio de informação. 
- Entendimento do acórdão:

9.2.3. a físcalização do cumprimento de metas de qualidade previstas nos contratos de concessão de serviços públicos não está abrangida na competência imediata do Tribunal de Contas da União; 9.2.4. atualmente se encontra em curso nesta Corte de Contas auditoria destinada a avaliar as ações de fiscalização da Aneel relacionadas à qualidade da prestação do serviço público de distribuição de energia elétrica (TC-013.046/2014-4), [...] cujos resultados serão oportunamente encaminhados aos signatários; 9.3. determinar à Agência Nacional de Energia Elétrica, com fulcro no art. 43, I, da Lei 8.443/1992, c/c o art. 250, II, do Regimento Interno/TCU, que remeta à Comissão de Trabalho, de Administração e Serviço Público da Câmara dos Deputados e ao Deputado Federal Eduardo da Fonte, cópia do processo de fiscalização realizado em 2014 na Companhia Energética de Pernambuco (Celpe) sobre os indicadores de continuidade e compensações financeiras aos consumidores, tão logo concluído $[\ldots]$.

8) Acórdão 2.314/2014 - Plenário

- Data da sessão: 03/09/2014.

- Relator: José Jorge.

- Área: competência do TCU.

- Tema: agência reguladora.

- Subtema: abrangência.

- Outros indexadores: fiscalização.

- Tipo do processo: solicitação do Congresso Nacional.

- Enunciado: "ao exercer o controle externo das atividades finalísticas das agências reguladoras, o TCU deve atuar de forma complementar, exercendo uma fiscalização de segunda ordem, preservando ao máximo o âmbito de competência dessas entidades públicas".

- Objeto: solicitação do Congresso Nacional, oriunda da Comissão de Defesa do Consumidor da Câmara dos Deputados, por meio da qual são requeridas informações relativas ao funcionamento e ao desempenho da Companhia Energética de Alagoas (Ceal), bem como à realização de auditoria nessa distribuidora para dirimir as dúvidas relacionadas ao seu Plano de Execução e Metodologia de Avaliação.

- Agência: Aneel.

- Unidade técnica: Secretaria de Fiscalização de Desestatização e Regulação de Energia e Comunicações (SefidEnergia).

- Emissão de comando relacionado à função reguladora? Não. 
- A análise da unidade técnica fiscalizadora foi acolhida pelo relator e pelo Plenário? Sim.

- Fundamento normativo: art. 71, VII, da Constituição Federal, c/c o art. 38, II, da Lei no 8.443/1992; art. 232, III, do Regimento Interno do TCU; e arts. 4", I, "b”, e 10 da Resolução TCU nº 215/2008.

- Precedentes citados: Acórdão 210/2013-TCU-Plenário (TC 024.260/2009-9).

- Enquadramento: função fiscalizadora.

(vi) Resultado do controle: solicitação de informações à Aneel sobre entidade regulada.

- Entendimento do acórdão: partindo do entendimento de que "o TCU, ao exercer o controle externo das atividades finalísticas das agências reguladoras, deve atuar de forma complementar, exercendo uma fiscalização de segunda ordem, preservando-se ao máximo o âmbito de competência dessas entidades públicas" (voto do relator), o TCU, buscando atender à demanda da Comissão de Defesa do Consumidor da Câmara dos Deputados, efetuou diligência para que a Aneel informasse, em relação à Ceal:

a) a periodicidade da leitura dos medidores de consumo de energia elétrica;

b) o percentual de consumidores faturado pela média do consumo;

c) a metodologia de faturamento e cobrança das contas de luz;

d) o nível de perdas e os montantes de recursos associados às perdas comerciais;

e) a evolução da tarifa de energia elétrica; e

f) os resultados provenientes de fiscalizações realizadas e demais dados de que disponha acerca do nível de qualidade dos serviços prestados. (voto do relator).

\section{9) Acórdão 2.241/2013 - Plenário}

- Data da sessão: 21/08/2013.

- Relator: José Múcio Monteiro.

- Área: competência do TCU.

- Tema: agência reguladora.

- Subtema: abrangência.

- Outros indexadores: determinação.

- Tipo do processo: acompanhamento.

- Enunciado: "a competência do TCU incide estritamente sobre a legalidade dos atos das agências reguladoras, excluindo-se a possibilidade de formulação de determinações sobre matéria técnica de competência delas." 
- Objeto: exame do acompanhamento da proposta de acordo concernente às dívidas da Libra Terminais 35 (Libra) e da Companhia Siderúrgica Paulista (Cosipa) com a Companhia Docas do Estado de São Paulo (Codesp) em virtude da determinação contida no Acórdão 1.036/2010-Plenário:

\begin{abstract}
9.4. determinar à Secretaria de Fiscalização de Desestatização (Sefid) que: 9.4.1. promova o acompanhamento da proposta de acordo formulada pela Cosipa, concernente à dívida com a Codesp no valor aproximado de R $\$ 27,9$ milhões [...], 9.4.2. promova o acompanhamento da proposta de acordo que vier a ser formulada, concernente à dívida da Libra Terminais 35 com a Codesp, contabilizada em contas a receber pelo montante de R $\$ 444,8$ milhões, em $31 / 12 / 2008$.
\end{abstract}

- Agência: Agência Nacional de Transportes Aquaviários (Antaq).

- Unidade técnica: Secretaria de Fiscalização de Desestatização e Regulação de Transportes (SefidTrans).

- Emissão de comando relacionado à função reguladora? Não, apenas solicitação de envio de informação sobre andamento de acordo no prazo de 60 dias.

- A análise da unidade técnica fiscalizadora foi acolhida pelo relator e pelo Plenário? Parcialmente.

- Fundamento normativo: art. 62, $\S 1^{\text {o }}$, da Lei $\mathrm{n}^{\mathrm{o}} 12.815 / 2013$; art. 169, V, do Regimento Interno do TCU.

- Precedentes citados: Acórdão 1.402/2010-Plenário, relatado pelo ministro Benjamin Zymler.

- Enquadramento: função fiscalizatória.

(vii) Resultado do controle: solicitação de envio de informação.

- Entendimento do acórdão:

\begin{abstract}
Observe-se que em relação à dívida da Cosipa, as partes firmaram um Termo de Acordo, em 28/12/2009, que foi homologado pelo Tribunal de Justiça do Estado de São Paulo no dia 29/12/2009, não havendo, assim, proposta de acordo a ser analisada pela unidade técnica, devendo ser tornado insubsistente o item 9.4.1 do Acórdão 1.036/2010-Plenário. Em relação à dívida da Libra Terminais $35 \mathrm{com}$ a Codesp, a unidade técnica relatou a evolução obtida no tratamento da questão, envolvendo, além da Companhia Docas, a Antaq, a Secretaria Especial de Portos (SEP) e a Advocacia-Geral da União.
\end{abstract}

No acórdão deliberou-se por:

9.1. tornar insubsistente, por perda de objeto, o item 9.4.1 do Acórdão 1.036/2010-Plenário; 9.2. considerar cumprido o item 9.4.2 do Acórdão 
1.036/2010-Plenário; 9.3. determinar à Agência Nacional de Transportes Aquaviários (Antaq) que informe ao Tribunal, no prazo de 60 (sessenta) dias, o andamento do acordo atinente à dívida da Libra Terminais 35 com a Codesp.

\section{0) Acórdão 569/2013 - Plenário}

- Data da sessão: 20/03/2013.

- Relator: Raimundo Carreiro.

- Área: pessoal.

- Tema: cargo em comissão.

- Subtema: remanejamento.

- Outros indexadores: limite mínimo, manutenção, agência reguladora.

- Tipo do processo: denúncia.

- Enunciado: “é possível a redistribuição de cargos comissionados em agência reguladora desde que mantida, como limite mínimo, a proporção original, definida em lei, entre o número de cargos técnicos e o número total de cargos comissionados da respectiva agência."

- Emissão de comando relacionado à função reguladora? Não. O caso não se relaciona ao exercício de função reguladora, por isso não entra na seleção. Apesar disso, sem pretender realizar julgamento quanto ao mérito da matéria (se o entendimento do TCU estava correto ou equivocado), há que se destacar que o tribunal proferiu entendimento com alto impacto na composição dos quadros de pessoal das agências.

\section{1) Acórdão 402/2013 - Plenário}

(viii) Data da sessão: 06/03/2013.

(ix) Relator: Raimundo Carreiro.

(x)Área: competência do TCU.

(xi) Tema: agência reguladora.

(xii) Subtema: abrangência.

(xiii) Outros indexadores: fiscalização, porto organizado.

(xiv) Tipo do processo: representação. 
(xv) Enunciado: "eventuais disfunções na atividade portuária devem, ao menos em um primeiro momento, ser resolvidas no âmbito da competência dos órgãos do setor portuário, especialmente a Secretaria Especial de Portos (SEP) e a Antaq. Somente se forem verificados atos contrários ao direito caberá ao TCU exigir a adoção das necessárias providências para o exato cumprimento do ordenamento jurídico".

(xvi) Objeto: representação formulada pela Federação Nacional dos Portuários para apuração de possíveis irregularidades em relação às autorizações para exploração de terminais privativos de uso misto.

(xvii) Agência: Antaq.

(xviii) Unidade técnica: Secretaria de Fiscalização e Desestatização e Regulação 1 (Sefid$1)$.

(xix) Emissão de comando relacionado à função reguladora? Não. Foi considerado improcedente o pedido da autora no sentido de requerer a apuração de eventuais irregularidades, suas repercussões cíveis, penais e disciplinares, bem como de seus responsáveis, inclusive. Os demais pedidos o TCU julgou prejudicados por perda de objeto em função da mudança do marco legal (superveniência da Medida Provisória $\mathrm{n}^{\mathrm{o}}$ 595, de 06/12/2012, que revogou a Lei dos Portos e fixou novo marco regulatório).

(xx) A análise da unidade técnica fiscalizadora foi acolhida pelo relator e pelo Plenário? Não.

(xxi) Fundamento normativo: art. 74, § 2º da Constituição Federal de 1988; art. 53 da Lei $n^{\circ} 8.443 / 1992$ (unidade técnica).

(xxii) Precedentes citados: Acórdão 2.210/2008-Plenário (área técnica); Acórdão 628/2008-Plenário (relator).

(xxiii) Enquadramento: atividade fiscalizatória e regulatória.

(xxiv) Resultado do controle: ausência de reverberação na função reguladora

(xxv) Entendimento do acórdão: improcedência do pedido do autor da representação no sentido de requerer a apuração de eventuais irregularidades, suas repercussões cíveis, penais e disciplinares, bem como seus responsáveis, e, inclusive, se fosse o caso, oficiar à Procuradoria-Geral da República. Os demais pedidos foram considerados prejudicados, por perda de objeto:

9.1.2.1. suspensão do funcionamento dos terminais de uso misto que não comprovem a preponderância de movimentação de carga própria; 9.1.2.2. promoção da adequação das autorizações já expedidas aos termos legais; 9.1.2.3. explicitação do conceito de carga própria, levando-se em conta o traço de verticalização, de modo que a produção e o seu escoamento via porto 
componham os elos de uma mesma cadeia econômica; 9.1.2.4. exigência para a outorga das autorizações estudo de viabilidade técnica e econômica que justifique, por si só, a construção e a operação de terminais privativos de uso misto, em consonância com a Resolução - Antaq 517/2005 e o Decreto $6.620 / 2008$.

Destaque-se, ainda assim, que se determinou à SefidTrans que autuasse o processo e, no prazo de trinta dias após a promulgação/sanção da Medida Provisória no 595/2012, concluísse estudos sobre os impactos no setor portuário e nos serviços de dragagem.

\section{2) Acórdão 210/2013 - Plenário}

(xxvi) Data da sessão: 20/02/2013.

(xxvii) Relator: José Jorge.

(xxviii) Área: competência do TCU.

(xxix) Tema: agência reguladora.

(xxx) Subtema: abrangência.

(xxxi) Outros indexadores: ilegalidade, atividade-fim, fiscalização, omissão.

(xxxii) Tipo do processo: solicitação do Congresso Nacional.

(xxxiii) Enunciado: "não compete ao TCU fiscalizar diretamente as empresas delegatárias de serviço público, mas sim examinar se o poder concedente físcaliza de forma adequada a execução dos contratos celebrados, visto que entendimento contrário implicaria invasão do TCU na seara de atuação das agências reguladoras, esvaziando a competência dessas entidades. Tratando-se da atividade-fim das referidas autarquias especiais, não deve o TCU se substituir à entidade controlada, tampouco estabelecer o conteúdo do ato de competência da agência, determinando-lhe a adoção de medidas, salvo quando for constatada ilegalidade ou omissão no cumprimento de normas jurídicas pertinentes."

(xxxiv)Objeto: solicitação do Congresso Nacional, formulada pela Comissão de Meio Ambiente, Defesa do Consumidor e Fiscalização e Controle do Senado Federal (CMA), com vistas à realização de auditoria operacional na execução dos contratos de concessão de serviços públicos de telefonia fixa e móvel, especificamente quanto aos mecanismos de cobrança dos usuários.

(xxxv) Fundamento normativos: art. 71, IV, da Constituição Federal; arts. 1º, II, e 38, I, da Lei ${ }^{\circ} 8.443$, de 1992. 
(xxxvi)Agência: Anatel.

(xxxvii) Unidade técnica: SefidEnergia.

(xxxviii) Emissão de comando relacionado à função reguladora? sim.

(xxxix)A análise da unidade técnica fiscalizadora foi acolhida pelo relator e pelo Plenário?

Parcialmente.

(xl) Fundamento normativo: art. 43, I, da Lei ${ }^{\circ}$ 8.443/1992; art. 250, II, do Regimento Interno do TCU.

(xli) Precedentes citados: não há precedentes citados.

(xlii) Enquadramento: adjudicatória e fiscalizatória.

(xliii) Resultado do controle: recomendação.

(xliv) Entendimento do acórdão: Foram acatadas as razões expostas pelo relator, e o TCU determinou à Anatel que estudasse a viabilidade de realizar auditoria específica nos sistemas de cobrança e faturamento das prestadoras do Serviço Móvel Pessoal (SMP), contemplando questões indicadas pela Corte. Reitera-se entendimento, já sustentado em outros acórdãos, de que

\footnotetext{
Não compete ao TCU fiscalizar diretamente as empresas delegatárias de serviço público, mas sim examinar se o poder concedente fiscaliza de forma adequada a execução dos contratos celebrados, visto que entendimento contrário implicaria invasão do TCU na seara de atuação das agências reguladoras, esvaziando a competência dessas entidades. Tratando-se da atividade-fim das referidas autarquias especiais, não deve o TCU se substituir à entidade controlada, tampouco estabelecer o conteúdo do ato de competência da agência, determinando-lhe a adoção de medidas, salvo quando for constatada ilegalidade ou omissão no cumprimento de normas jurídicas pertinentes.
}

Porém, interpretação conferida a esse entendimento pela área técnica, relator e plenário é diferente: aquela adota postura mais interventiva do que os dois últimos em relação ao nível de interferência do TCU nas atividades das agências reguladoras (ARs).

\section{3) Acórdão 2.302/2012 - Plenário}

(xlv) Data da sessão: 29/08/2012.

(xlvi) Relator: Raimundo Carreiro.

(xlvii) Área: competência do TCU.

(xlviii) Tema: agência reguladora.

(xlix) Subtema: abrangência. 
(1) Outros indexadores: fiscalização.

(li) Tipo do processo: representação.

(lii) Enunciado: "a fiscalização do TCU sobre as agências reguladoras é de segunda ordem, cabendo a estas a fiscalização de primeira ordem, bem como as escolhas regulatórias, e ao TCU verificar se não houve ilegalidade ou irregularidade na atuação dessas autarquias especiais".

(liii) Objeto: agravo em representação interposto pelo procurador-geral do Ministério Público perante o Tribunal de Contas da União (MP/TCU), Lucas Rocha Furtado (peça 49, p. 1-3):

\begin{abstract}
em face de Despacho exarado pelo Ministro-Relator do TC 010.594/2012-4 (peça 30), submetido à apreciação do Plenário desta Corte de Contas em 17/5/2012, cuja deliberação decidiu pela revogação de medida cautelar, concedida anteriormente, que suspendeu a homologação do resultado do leilão referente ao Edital de Concessão 1/2011, da Agência Nacional de Transportes Terrestres (ANTT), relativo à concessão dos serviços de operação, recuperação, manutenção, conservação, implantação de melhorias e ampliação da capacidade do trecho da Rodovia BR-101, compreendido entre o entroncamento com a Rodovia BA-698 (Mucuri/BA) e a divisa do Estado do Espírito Santo com o do Rio de Janeiro.
\end{abstract}

(liv) Agência: ANTT.

(lv) Unidade técnica: Sefid 1 (relatório adotado com fundamento no art. $1^{\circ}, \S 3^{\circ}$, I, da Lei $\left.\mathrm{n}^{\circ} 8.443 / 1992\right)$.

(lvi) Emissão de comando relacionado à função reguladora? Não.

(lvii) A análise da unidade técnica fiscalizadora foi acolhida pelo relator e pelo Plenário? Pelo relator, não. Pelo plenário, sim (negação de provimento ao agravo).

(lviii) Fundamento normativo: arts. 16, II, e 43, I, da Lei Orgânica do TCU; art. 289 do Regimento Interno do TCU; art. 26, VI, da Lei $n^{\circ}$ 10.233/2001 (unidade técnica e reproduzido na declaração de voto). Acórdão: arts. 144, § 2º 146, 237, VI, e 289 do Regimento Interno.

(lix) Precedentes citados: mencionam jurisprudência da Corte sem citar nenhum precedente em específico.

(lx) Enquadramento: função adjudicatória.

(1xi) Resultado do controle: ausência de reverberação na função reguladora.

(lxii) Entendimento do acórdão:

Voto do relator: 
Destarte, ao restabelecer a Medida Cautelar anteriormente concedida nos presentes autos, Voto no sentido de que o Tribunal adote o Acórdão que submeto à elevada apreciação deste Colegiado.

9.1. ratificar o conhecimento da Representação da lavra do Procurador-Geral do Ministério Público junto ao Tribunal de Contas da União (MP/TCU), deixando e apreciar seu mérito nesta oportunidade;

9.2. deferir o pedido de ingresso dos Consórcios Rodovia da Vitória e Rodovia Capixaba neste processo de Representação;

9.3. conhecer do Agravo interposto pelo Procurador-Geral do Ministério Público junto ao Tribunal de Contas da União (MP/TCU) para, no mérito, dar-lhe provimento, alcançando esta Decisão a parte final do requerido pelo Consórcio Rodovia Capixaba, nos termos do art. 281 do Regimento Interno do TCU;

9.4. restabelecer a Medida Cautelar anteriormente concedida (peça 8), no sentido de determinar à Agência Nacional de Transportes Terrestres (ANTT) que se abstenha de assinar o contrato resultante do leilão referente ao Edital de Concessão 001/2011 - Concessão para Exploração de Trechos da Rodovia BR101/ES/BA, até que se julgue o mérito do processo TC 003.499/2011-1;

9.5. dar ciência desta deliberação, acompanhada do Relatório e Voto que a fundamentam, à ANTT, ao Procurador-Geral do MP/TCU, aos Consórcios Rodovia Capixaba e Rodovia da Vitória; [...].

Acórdão:

ACORDAM os Ministros do Tribunal de Contas da União, reunidos em Sessão do Plenário, diante das razões expostas pelo Redator, e com fundamento nos arts. $144, \S 2^{\circ}, 146,237, \mathrm{VI}$, e 289 do Regimento Interno, em:

9.1. ratificar o conhecimento da Representação do Procurador-Geral do Ministério Público junto ao Tribunal de Contas da União (MP/TCU);

9.2. deferir o pedido de ingresso, nos autos do processo de Representação, como interessados, dos Consórcios Rodovia da Vitória e Rodovia Capixaba;

9.3. conhecer do Agravo interposto pelo Procurador-Geral do Ministério Público junto ao Tribunal de Contas da União (MP/TCU), para, no mérito, negar-lhe provimento, por falta de plausibilidade jurídica do pedido e de ausência de periculum in mora, nos fatos apresentados;

9.4. informar a Agência Nacional de Transportes Terrestres (ANTT) que não há, no TCU, óbice à continuidade do procedimento do leilão referente ao Edital de Concessão 001/2011 - Concessão para Exploração de Trechos da Rodovia BR101/ES/BA, permanecendo, todavia, o mérito do processo TC 003.499/2011-1 ainda sujeito a julgamento;

9.5. dar ciência desta deliberação, acompanhada do Relatório e Voto que a fundamentam, à ANTT, ao Procurador-Geral do MP/TCU, aos Consórcios Rodovia Capixaba e Rodovia da Vitória.

\section{4) Acórdão 3.234/2011 - Plenário}

(lxiii) Data da sessão: 07/12/2011.

(lxiv) Relator: Aroldo Cedraz.

(lxv) Área: desestatização.

(lxvi) Tema: concessão pública.

(lxvii) Subtema: revisão tarifária. 
(lxviii) Outros indexadores: concessionária, receita.

(lxix) Tipo do processo: desestatização.

(lxx) Enunciado: "a agência reguladora deve incluir na minuta de contrato de concessão mecanismo destinado a garantir, durante a execução contratual, a reversão de receitas não tarifárias em prol da modicidade das tarifas e/ou dos preços específicos praticados no próprio objeto da concessão".

(lxxi) Objeto: acompanhamento do processo concessório para ampliação, manutenção e exploração do Aeroporto Internacional de Viracopos.

(lxxii) Agência: Agência Nacional de Aviação Civil (Anac).

(lxxiii) Unidade técnica: Sefid-1.

(lxxiv) Emissão de comando relacionado à função reguladora? Sim.

(lxxv) A análise da unidade técnica fiscalizadora foi acolhida pelo relator e pelo Plenário? Sim.

(lxxvi) Fundamentos normativos: art. 258, II, do Regimento Interno do TCU, c/c o art. $7^{\circ}$, I, da Instrução Normativa TCU no 27/1998; art. 43, I, da Lei $n^{\circ}$ 8.443/1992, c/c o art. 250, II, do Regimento Interno do TCU, obediência aos princípios da economicidade e da eficiência; art. 14, II, do Decreto no 7.624/2011; art. 29, X, da Lei no 8.987/1995, c/c o art. $7^{\circ}, \S 1^{\mathrm{o}}$, do Decreto $\mathrm{n}^{\mathrm{o}} 7.624 / 2011$.

(lxxvii) Precedentes citados: Acórdãos 939/2010-TCU, 693/2007, 851/2009, 1.510/2010, 1.397/2010-TCU-Plenário, 241/2009-TCU-Plenário, 682/2010, 683/2010, 684/2010-TCU-Plenário, 939/2011-TCU-Plenário e 1.795/2011-TCU-Plenário (Fator $\mathrm{X})$.

(lxxviii) Enquadramento: atividade adjudicatória.

(lxxix) Resultado do controle: determinações e recomendações.

(lxxx) Entendimento do acórdão: aprovação, com ressalvas, do primeiro estágio de fiscalização da outorga de concessão para ampliação, manutenção e exploração do Aeroporto Internacional de Viracopos, em Campinas (SP), condicionando a publicação do edital a diversas alterações de ordem técnica: (i) redução das estimativas de valores de investimentos considerados nos estudos da modelagem correspondentes às superestimativas apuradas pela $1^{\text {a }}$ Secretaria de Fiscalização de Obras; (ii) inclusão, na minuta contratual, do dever de a concessionária cumprir integralmente as condicionantes ambientais ainda não atendidas das licenças prévias e de instalação já obtidas pelo poder concedente; (iii) especificação, na minuta contratual, da parte a quem será imputado o ônus pelo atraso nas obras decorrente da demora de obtenção de 
licenças ambientais quando os prazos de análise do órgão ambiental responsável pela emissão das licenças ultrapassarem as previsões legais; (iv) a fim de resguardar a prestação de serviço adequado ao pleno atendimento dos usuários do aeroporto, nos termos do art. $6^{\circ}$, caput, e $\S 1^{\circ}$, da Lei $n^{\circ} 8.987 / 1995$, elaboração e envio ao TCU, no prazo de 150 dias, de plano de ação, incluindo atividades, prazos e responsáveis, voltado à implementação de providências destinadas ao estabelecimento: 1) das métricas de utilização para as instalações do lado ar do aeroporto; e 2) dos padrões de desempenho dos indicadores de qualidade de serviço adotados para a concessão, informando, inclusive, o prazo previsto para a realização das respectivas consultas ou audiências públicas; (v) para o regime tarifário do contrato de concessão, utilização de fórmula de reversão de ganhos de eficiência e de produtividade em favor dos usuários do serviço outorgado que efetivamente reflita o incremento de eficiência e de produtividade obtido pela futura concessionária, a teor do que dispõe o art. 29, X, da Lei $\mathrm{n}^{\mathrm{o}} 8.987 / 1995, \mathrm{c} / \mathrm{c}$ o art. $7^{\mathrm{o}}, \S 1^{\mathrm{o}}$, do Decreto 7.624/2011. Especificamente no que concerne ao processo de outorga do Aeroporto Internacional de Viracopos, em Campinas (SP), determinou-se à Anac que: (i) examine a necessidade de participação da Infraero na futura SPE ou estabeleça, na minuta de contrato, mecanismo que possibilite e estimule a diminuição gradativa dessa participação no capital social da concessionária; (ii) inclua na minuta de contrato de concessão as especificações técnicas essenciais para a caracterização dos investimentos mínimos obrigatórios em obras e equipamentos, compatíveis com o padrão de qualidade adotado como referência nas estimativas de custos apresentadas no estudo de viabilidade, contendo, além das áreas mínimas previstas para cada componente, o padrão de acabamento e a qualidade dos materiais, bem como qualquer outra informação necessária para subsidiar a elaboração das propostas pelos proponentes; (iiii) adote no Plano de Exploração Aeroportuária, para a Fase 1-B (Fase 0 dos estudos de viabilidade), a área total mínima de $59.000 \mathrm{~m}^{2}$ para as novas áreas destinadas a terminal de passageiros, conforme previsto nos estudos de viabilidade e de forma a atender a demanda na hora-pico; (iv) revise o Plano de Exploração Aeroportuária de forma que o documento reflita os parâmetros utilizados nos estudos de viabilidade, a fim de assegurar tanto a consistência dos documentos quanto o adequado dimensionamento das áreas disponíveis para os usuários do aeroporto; (v) inclua na minuta de contrato de concessão mecanismo destinado a garantir, durante a execução contratual, a reversão de receitas não tarifárias em prol da modicidade das tarifas e/ou dos preços específicos praticados no próprio aeroporto; (vi) 
reconsidere a fixação do padrão mínimo para os itens "conforto e disponibilidade de assentos no saguão de embarque e outras áreas públicas" e "disponibilidade de vagas de estacionamento", elevando-os de forma a harmonizá-los com o limite mínimo imposto aos demais indicadores de qualidade do aeroporto a serem aferidos por meio de pesquisa de satisfação dos passageiros.

\section{5) Acórdão 3.233/2011 - Plenário}

(lxxxi) Data da sessão: 07/12/2011.

(lxxxii) Relator: Aroldo Cedraz.

(lxxxiii) Área: desestatização.

(lxxxiv) Tema: concessão pública.

(lxxxv)Subtema: revisão tarifária.

(lxxxvi) Outros indexadores: concessionária, eficiência, produtividade.

(lxxxvii) Tipo do processo: desestatização.

(lxxxviii) Enunciado: “a agência reguladora deve utilizar fórmula de reversão de ganhos de eficiência e de produtividade em favor dos usuários do serviço outorgado que efetivamente reflita o incremento de eficiência e de produtividade obtido pela futura concessionária, a teor do que dispõe o art. 29, X, da Lei $\mathrm{n}^{\circ} 8.987 / 1995$, c/c o art. $7^{\circ}, \S$ $1^{\circ}$, do Decreto $n^{\circ} 7.624 / 2011 . "$

(lxxxix) Objeto: acompanhamento do processo concessório para ampliação, manutenção e exploração do Aeroporto Internacional Presidente Juscelino Kubitschek (Aeroporto Internacional de Brasília).

(xc) Agência: Anac.

(xci) Unidade técnica: Sefid-1.

(xcii) Emissão de comando relacionado à função reguladora? Sim.

(xciii) Análise da unidade técnica fiscalizadora foi acolhida pelo relator e pelo Plenário? Sim.

(xciv) Fundamento normativo: art. 258, II, do Regimento Interno do TCU, c/c o art. $7^{\circ}$, I, da Instrução Normativa TCU no 27/1998; art. 43, I, da Lei no 8.443/1992, c/c o art. 250, II, do Regimento Interno do TCU, obediência aos princípios da economicidade e da eficiência; art. 14, II, do Decreto n $n^{\circ} 7.624 / 2011$; art. 29, X, da Lei no 8.987/1995, c/c o art. $7^{\mathrm{o}}, \S 1^{\mathrm{o}}$, do Decreto $\mathrm{n}^{\mathrm{o}} 7.624 / 2011$. 
(xcv) Precedentes citados: Acórdãos 939/2010-TCU, 693/2007, 851/2009 e 1.510/2010, todos proferidos pelo Plenário do TCU na linha de que a necessidade de que os elementos mínimos de projeto básico sejam suficientes é imposta pelo princípio da isonomia, requisito fundamental nas licitações, pois só é possível garantir a vantagem da proposta vencedora se não houver ofensa à isonomia entre os licitantes. Acórdãos 1.397/2010-TCU-Plenário e 241/2009-TCU-Plenário, para que a agência se abstenha de encaminhar ao TCU estudos de viabilidade técnica, econômico-financeira e ambiental de que trata o art. $7^{\circ}$, I, da Instrução Normativa TCU n ${ }^{\circ} 27 / 1998$, contendo premissas desprovidas de amparo legal e regulamentar, bem assim antes de concluídas as providências internas (e.g. decisões essenciais acerca da modelagem da outorga) que confiram feição final ao projeto de concessão. Diante disso, considera-se desnecessário formular idêntica nomeclatura a ser adotada para "receitas alternativas, complementares, acessórias ou de projetos associados”, genericamente denominadas “receitas extraordinárias” (Acórdãos 682/2010, 683/2010 e 684/2010-TCU-Plenário), sendo que, nos estudos de viabilidade técnica, econômica e ambiental (EVTEA) em tela, surgem como "receitas não tarifárias" ou "receitas comerciais". Sobre deficiência quanto às especificações dos elementos mínimos de projeto, o Acórdão 939/2011-TCUPlenário, em que se determinou a inclusão, no edital de licitação, de especificações técnicas essenciais para a caracterização dos investimentos mínimos obrigatórios, e o Acórdão 1.795/2011-TCU-Plenário (Fator X).

(xcvi) Enquadramento: função adjudicatória.

(xcvii) Resultado do controle: determinações e recomendações.

(xcviii)Acórdão: foi aprovado com ressalvas o primeiro estágio de fiscalização da outorga de concessão para a ampliação, manutenção e exploração do Aeroporto Internacional Presidente Juscelino Kubitschek, em Brasília (DF), condicionando a publicação do edital à adoção de providências de ordem técnica pela Agência Nacional de Aviação Civil, relativas a: (i) estimativas de investimentos; (ii) questões referentes ao licenciamento ambiental e a previsão contratual do risco de atraso do licenciamento pela demora do prazo de análise pelo órgão ambiental; (iii) exigência de apresentação, no prazo de 150 dias, de plano de ação, incluindo atividades, prazos e responsáveis, voltado à implementação de providências destinadas ao estabelecimento das métricas de utilização para as instalações do lado ar do aeroporto e dos padrões de desempenho dos indicadores de qualidade de serviço adotados para a concessão; (iv) regime tarifário do contrato de concessão, determinando a utilização de fórmula de reversão de ganhos de 
eficiência e de produtividade em favor dos usuários do serviço outorgado que efetivamente reflita o incremento de eficiência e de produtividade obtido pela futura concessionária. Recomendações no sentido de que a Anac: (i) examine a necessidade de participação da Empresa Brasileira de Infraestrutura Aeroportuária (Infraero) na futura SPE ou estabeleça, na minuta de contrato, mecanismo que possibilite e estimule a diminuição gradativa dessa participação no capital social da concessionária; (ii) inclua na minuta de contrato de concessão as especificações técnicas essenciais para a caracterização dos investimentos mínimos obrigatórios em obras e equipamentos, compatíveis com o padrão de qualidade adotado como referência nas estimativas de custos apresentadas no estudo de viabilidade, contendo, além das áreas mínimas previstas para cada componente, o padrão de acabamento e a qualidade dos materiais, bem como qualquer outra informação necessária para subsidiar a elaboração das propostas pelos proponente; (iii) adote, no Plano de Exploração Aeroportuária, para a Fase 1-B (Fase 0 dos estudos de viabilidade), a área total mínima de $43.000 \mathrm{~m}^{2}$ para as novas áreas destinadas a terminal de passageiros, conforme previsto nos estudos de viabilidade e de forma a atender a demanda na hora-pico; (iv) revise o Plano de Exploração Aeroportuária de forma que o documento reflita os parâmetros utilizados nos estudos de viabilidade, a fim de assegurar tanto a consistência dos documentos quanto o adequado dimensionamento das áreas disponíveis para os usuários do aeroporto; (v) inclua na minuta de contrato de concessão mecanismo destinado a garantir, durante a execução contratual, a reversão de receitas não tarifárias em prol da modicidade das tarifas e/ou dos preços específicos praticados no próprio aeroporto; (vi) reconsidere a fixação do padrão mínimo para os itens "conforto e disponibilidade de assentos no saguão de embarque e outras áreas públicas" e "disponibilidade de vagas de estacionamento", elevando-os de forma a harmonizá-los com o limite mínimo imposto aos demais indicadores de qualidade do aeroporto.

\section{6) Acórdão 3.232/2011 - Plenário}

(xcix) Data da sessão: 07/12/2011.

(c)Relator: Aroldo Cedraz.

(ci) Área: desestatização.

(cii) Tema: concessão pública. 
(ciii) Subtema: revisão tarifária.

(civ) Outros indexadores: concessionária, receita.

(cv) Tipo do processo: desestatização.

(cvi) Enunciado: a agência reguladora deve incluir na minuta de contrato de concessão mecanismo destinado a garantir, durante a execução contratual, a reversão de receitas não tarifárias em prol da modicidade das tarifas e/ou dos preços específicos praticados no próprio objeto da concessão.

(cvii) Objeto: acompanhamento do processo concessório para ampliação, manutenção e exploração do Aeroporto Internacional de Viracopos.

(cviii) Agência: Anac.

(cix) Unidade técnica: Sefid-1.

(cx) Emissão de comando relacionado à função reguladora? Sim.

(cxi) A análise da unidade técnica fiscalizadora foi acolhida pelo relator e pelo Plenário? Sim.

(cxii) Fundamentos: art. 258, II, do Regimento Interno do TCU, c/c o art. $7^{\mathrm{o}}$, I, da Instrução Normativa TCU no 27/1998; art. 43, I, da Lei no 8.443/1992, c/c o art. 250, II, do Regimento Interno do TCU, obediência aos princípios da economicidade e da eficiência; art. 14, II, do Decreto n ${ }^{\circ}$ 7.624/2011; art. 29, X, da Lei $n^{\circ} 8.987 / 1995$, c/c o art. $7^{\mathrm{o}}, \S 1^{\mathrm{o}}$, do Decreto $\mathrm{n}^{\mathrm{o}} 7.624 / 2011$.

(cxiii) Precedentes citados: Acórdãos 939/2010-TCU, 693/2007, 851/2009 e 1.510/2010, todos proferidos pelo Plenário do TCU na linha de que a necessidade de que os elementos mínimos de projeto básico sejam suficientes é imposta pelo princípio da isonomia, requisito fundamental nas licitações, pois só é possível garantir a vantagem da proposta vencedora se não houver ofensa à isonomia entre os licitantes. Acórdãos 1.397/2010-TCU-Plenário e 241/2009-TCU-Plenário, para que agência se abstenha de encaminhar ao TCU estudos de viabilidade técnica, econômico-financeira e ambiental de que trata o art. $7^{\circ}$, I, da Instrução Normativa TCU n $n^{\circ}$ 27/1998, contendo premissas desprovidas de amparo legal e regulamentar, bem assim antes de concluídas as providências internas (e.g. decisões essenciais acerca da modelagem da outorga) que confiram feição final ao projeto de concessão. Diante disso, considera-se desnecessário formular idêntica nomeclatura a ser adotada para "receitas alternativas, complementares, acessórias ou de projetos associados", genericamente denominadas “receitas extraordinárias" (Acórdãos n n ${ }^{\text {os }}$ 682/2010, 683/2010 e 684/2010-TCUPlenário), sendo que, nos EVTEA em tela, surgem como "receitas não tarifárias" ou 
"receitas comerciais". Sobre deficiência quanto às especificações dos elementos mínimos de projeto, o Acórdão 939/2011-TCU-Plenário, em que se determinou a inclusão no edital de licitação de especificações técnicas essenciais para a caracterização dos investimentos mínimos obrigatórios, e o Acórdão 1.795/2011-TCUPlenário (Fator X).

(cxiv) Enquadramento: atividade adjudicatória.

(cxv) Resultado do controle: determinações/comandos e recomendações.

(cxvi) Acórdão: aprovado, com ressalvas, o primeiro estágio de fiscalização da outorga de concessão para ampliação, manutenção e exploração do Aeroporto Internacional Governador André Franco Montoro, em Guarulhos (SP), condicionando a publicação do edital à adoção, com fulcro no art. 43, I, da Lei n ${ }^{\circ}$ 8.443/1992, c/c o art. 250, II, do Regimento Interno do TCU, das seguintes providências pela Agência Nacional de Aviação Civil:

9.1.1. em obediência aos princípios da economicidade e da eficiência, e com fulcro no art. $3^{\circ}$ da Lei 8.666/1993 e no art. 15, inciso II, da Lei 8.987/1995, deduza de suas estimativas de investimentos alocados para a futura concessionária os valores de R \$ 757,72 milhões na Fase 0 , R \$ 506,60 milhões na Fase 1, R\$ 241,61 milhões na Fase 2 e R\$ 125,45 milhões na Fase 3, correspondentes às superestimativas apuradas pela $1^{\text {a }}$ Secretaria de Fiscalização de Obras, nos termos do parecer acostado à peça 188 destes autos;

9.1.2 corrija, no estudo ambiental, o tipo e o número da licença ambiental referente às obras parciais de terraplanagem;

9.1.3. em virtude do disposto no art. 14, inciso II, do Decreto 7.624/2011 e do que consta nos estudos de viabilidade ambiental apresentados a este Tribunal:

9.1.3.1 inclua na minuta contratual o dever de a concessionária cumprir integralmente as condicionantes ambientais ainda não atendidas das licenças prévias e de instalação já obtidas pelo poder concedente;

9.1.3.2 especifique na minuta contratual a quem será imputado o ônus pelo atraso nas obras decorrente da demora de obtenção de licenças ambientais quando os prazos de análise do órgão ambiental responsável pela emissão das licenças ultrapassarem as previsões legais;

9.1.3.3 especifique na minuta contratual a quem será imputado o ônus no caso de confirmação de existência de contaminação de solo e águas subterrâneas na área do aeroporto que seja anterior à publicação do edital do leilão da concessão;

9.2 determinar à Agência Nacional de Aviação Civil (Anac), com fundamento no art. 43, inciso I, da Lei 8.443/1992 c/c o art. 250, inciso II, do Regimento Interno do TCU, que:

9.2.1 abstenha-se de encaminhar a este Tribunal os estudos de viabilidade técnica, econômico-financeira e ambiental de que trata o art. $7^{\circ}$, inciso I, da IN TCU 27/1998 contendo premissas desprovidas de amparo legal e regulamentar; 9.2.2 no que concerne ao processo de concessão do Aeroporto Internacional Governador André Franco Montoro, em Guarulhos/SP, a fim de resguardar a prestação de serviço adequado ao pleno atendimento dos usuários do aeroporto, nos termos do art. $6^{\circ}$, caput e $\S 1^{\circ}$, da Lei $8.987 / 1995$, elabore e envie ao TCU, no prazo de 150 (cento e cinquenta) dias, plano de ação, incluindo atividades, prazos e responsáveis, voltado à implementação de providências destinadas ao estabelecimento: (a) das métricas de utilização para as instalações do lado ar do aeroporto e; (b) dos padrões de desempenho dos Indicadores de Qualidade de 
Serviço adotados para a concessão; informando, inclusive, o prazo previsto para a realização das respectivas consultas ou audiências públicas;

9.2.3 para o regime tarifário do contrato de concessão do Aeroporto Internacional Governador André Franco Montoro, em Guarulhos/SP, utilize fórmula de reversão de ganhos de eficiência e de produtividade em favor dos usuários do serviço outorgado que efetivamente reflita o incremento de eficiência e de produtividade obtido pela futura concessionária, a teor do que preconiza o inciso X do art. 29 da Lei Geral das Concessões c/c o art. $7^{\circ}, \S 1^{\circ}$, do Decreto 7.624/2011;

9.3 com fundamento no art. 43, inciso I, da Lei 8.443/1992 c/c o art. 250, inciso II, do Regimento Interno do TCU, determinar à Secretaria de Aviação Civil da Presidência da República que apresente ao TCU, no prazo de 90 (noventa) dias, plano de ações, contendo cronograma e indicação de responsáveis, destinado à elaboração da regulamentação do Fundo Nacional de Aviação Civil (FNAC), conforme disposto no art. $12, \S 1^{\circ}$, do Decreto 7.624/2011;

9.4 recomendar à Agência Nacional de Aviação Civil (Anac), com fundamento no art. 43, inciso I, da Lei 8.443/1992 c/c o art. 250, inciso III, do Regimento Interno do TCU, que:

9.4.1 sistematize, em conjunto com a Infraero e preferencialmente sob coordenação da Secretaria de Aviação Civil da Presidência da República, as informações existentes referentes a aspectos ambientais dos aeroportos públicos brasileiros, criando um banco de dados para subsidiar a análise dos custos ambientais para futuros projetos de concessões;

9.4.2 crie indicadores para avaliar o desempenho da gestão ambiental dos operadores aeroportuários;

9.4.3 nas modelagens de futuras concessões aeroportuárias, adote variáveis regionais em seus modelos de previsão de demanda;

9.4.4 nas modelagens de futuras concessões aeroportuárias, abstenha-se de proceder a ajustes arbitrários nos resultados gerados pelos modelos quantitativos escolhidos, de forma a manter a robustez e a consistência dos estudos de demanda;

9.5 com fundamento no art. 43, inciso I, da Lei 8.443/1992 c/c o art. 250, inciso III, do Regimento Interno do TCU recomendar à Agência Nacional de Aviação Civil (Anac), no que concerne ao processo de concessão do Aeroporto Internacional Governador André Franco Montoro, em Guarulhos/SP, que:

9.5.1 examine a necessidade de participação da Infraero na futura SPE ou que seja estabelecido, na minuta de contrato, mecanismo que possibilite e estimule a diminuição gradativa dessa participação no capital social da concessionária;

9.5.2 abstenha-se de incluir no edital do leilão vedação de participação dos autores ou responsáveis economicamente por projeto, estudo, levantamento ou investigação apresentados em atenção aos termos do Edital de Chamamento Público de Estudos (CPE) 1/2011, pelo risco de afronta ao princípio da ampla concorrência;

9.5.3 inclua na minuta de contrato de concessão as especificações técnicas essenciais para a caracterização dos investimentos mínimos obrigatórios em obras e equipamentos, compatíveis com o padrão de qualidade adotado como referência nas estimativas de custos apresentadas no estudo de viabilidade, contendo, além das áreas mínimas previstas para cada componente, o padrão de acabamento e a qualidade dos materiais, bem como qualquer outra informação necessária para subsidiar a elaboração das propostas pelos proponentes;

9.5.4 adote no Plano de Exploração Aeroportuária, para a Fase 1-B (Fase 0 dos estudos de viabilidade), a área total mínima de $100.000 \mathrm{~m}^{2}$ para as novas áreas destinadas a terminal de passageiros, conforme previsto nos estudos de viabilidade e de forma a atender a demanda na hora-pico;

9.5.5 revise o Plano de Exploração Aeroportuária de forma que o documento reflita os parâmetros utilizados nos estudos de viabilidade, de forma a assegurar tanto a consistência dos documentos quanto o adequado dimensionamento das áreas disponíveis para os usuários do aeroporto; 9.5.6 averigue a situação de cada termo de compromisso ambiental pendente de atendimento e demonstre, nos estudos ambientais, todos os valores de 
compensação ambiental que devem ser assumidos pela concessionária, com base nas informações contidas nas licenças e autorizações ambientais válidas;

9.5.7 reconsidere a fixação do padrão mínimo para os itens "conforto e disponibilidade de assentos no saguão de embarque e outras áreas públicas", e "disponibilidade de vagas de estacionamento", elevando-os de forma a harmonizá-los com o limite mínimo imposto aos demais indicadores de qualidade do aeroporto a serem aferidos por meio de pesquisa de satisfação dos passageiros;

9.5.8 inclua na minuta de contrato de concessão mecanismo destinado a garantir, durante a execução contratual, a reversão de receitas não tarifárias em prol da modicidade das tarifas e/ou dos preços específicos praticados no próprio aeroporto;

9.6 com fundamento no art. 43, inciso I, da Lei 8.443/1992 c/c o art. 250, inciso III, do Regimento Interno do TCU, recomendar à Casa Civil da Presidência da República, à Secretaria de Aviação Civil da Presidência da República (SAC/PR) e à Agência Nacional de Aviação Civil (Anac) que avaliem a oportunidade e conveniência de incorporar as áreas destinadas ao abastecimento de combustível de aviação no rol de "áreas essenciais" de que trata o art. $12, \S 1^{\circ}$, do Decreto $89.121 / 1983$, ante o risco de que a concessionária a operar o aeroporto venha a exercer poder de fixação de preços em níveis de monopólio;

$[\ldots]$

9.9. restituir os autos à Sefid-1 para que prossiga o acompanhamento do processo de concessão para a ampliação, manutenção e exploração do Aeroporto Internacional Governador André Franco Montoro, localizado em Guarulhos/SP.

\section{7) Acórdão 2.753/2011 - Plenário}

(cxvii) Data da sessão: 19/10/2011.

(cxviii)Relator: José Jorge.

(cxix) Área: licitação.

(cxx) Tema: pregão eletrônico.

(cxxi) Subtema: obrigatoriedade.

(cxxii) Outros indexadores: agência reguladora, serviços comuns, bens comuns.

(cxxiii)Tipo do processo: representação.

(cxxiv)Enunciado: é regra geral a utilização do pregão eletrônico para aquisição de bens e serviços comuns por parte de instituições públicas, nelas inclusas agências reguladoras, sendo o uso do pregão presencial hipótese de exceção, a ser justificada no processo licitatório.

(cxxv) Objeto: representação formulada pela $1^{\mathrm{a}}$ Secretaria de Controle Externo ( $1^{\mathrm{a}}$ Secex), apontando possíveis irregularidades no regulamento próprio de licitações da Anatel, o qual estaria em desconformidade com o ordenamento vigente por não adotar o pregão eletrônico. 
Para a unidade técnica, a quase totalidade dos pregões em andamento na Agência poderia ser realizada na forma eletrônica, o que, segundo ela, implicaria redução de preços. Assinalou, ainda, que a continuação das licitações, da forma como vêm sendo promovidas, sem o respeito às normas gerais de licitação e contratação, acarreta risco de lesão ao erário. Nesse contexto, tendo em conta a iminência da adjudicação de 3 (três) pregões pela Agência, pugnou pela presença dos elementos suficientes para a concessão de medida cautelar por esta Corte, com vistas a suspender o andamento de todos os pregões da Agência que estivessem em curso, bem como a publicação ou republicação de novos editais da modalidade que não respeitassem as normas gerais de licitação e contratação, não sem antes, entretanto, ouvir o Presidente da entidade para que informasse eventual existência de periculum in mora reverso, caso adotada a mencionada medida.

(cxxvi)Agência: Anatel.

(cxxvii) Unidade técnica: $1^{\mathrm{a}}$ Secex.

(cxxviii) Emissão de comando relacionado à função reguladora? Trata-se de caso que não envolve diretamente o exercício da função reguladora e, por isso, foi excluído do universo final de análise.

\section{8) Acórdão 683/2010 - Plenário}

(cxxix)Data da sessão: 07/04/2010.

(cxxx) Relator:Walton Alencar Rodrigues.

(cxxxi)Área: desestatização.

(cxxxii) Tema: rodovia.

(cxxxiii) Subtema: pedágio.

(cxxxiv) Outros indexadores: veículo, desgaste, princípio da isonomia.

(cxxxv) Tipo do processo: desestatização.

(cxxxvi) Enunciado: “é recomendável à agência reguladora considerar a possibilidade de instituir forma de pedágio que guarde maior proporcionalidade com o desgaste promovido pelo veículo na rodovia, em respeito ao princípio da isonomia."

(cxxxvii) Objeto: $1^{\mathrm{o}}$ estágio do acompanhamento do procedimento licitatório para outorga da concessão da rodovia federal BR-040, trecho de 936,80 km compreendido entre Brasília (DF) e Juiz de Fora (MG).

(cxxxviii) Agência: ANTT.

(cxxxix) Unidade técnica: Sefid; Secob.

(cxl) Emissão de comando relacionado à função reguladora? Sim. 
(cxli) A análise da unidade técnica fiscalizadora foi acolhida pelo relator e pelo Plenário? Sim.

(cxlii) Fundamento normativo: art. 43, I, da Lei $n^{\circ}$ 8.443/1992; art. 250, II, do Regimento Interno do TCU; art. 18, IV e XV, da Lei no 8.987/1995; Instrução Normativa TCU n ${ }^{\circ}$ 46/2004.

(cxliii) Precedentes citados: Acórdão 2.104/2008-TCU-Plenário ( $1^{\circ}$ estágio de acompanhamento da concessão de trechos da BR-116 e da BR-324 no estado da Bahia); Acórdãos 851/2009 e n 2.047/2006-TCU-Plenário (referentes às exigências atreladas a elementos do projeto básico para fins de concessão).

(cxliv) Enquadramento: atividade adjudicatória.

(cxlv) Resultado do controle: determinações e recomendações.

(cxlvi) Acórdão: determinação à ANTT para que retifique e complete os estudos que embasam a concessão rodoviária, ficando vedada a publicação de edital.

Por essas razões, não há possibilidade de realizar procedimento licitatório sem que a estimativa de investimento esteja adequadamente justificada em estudos que evidenciem o estado da rodovia, os melhoramentos necessários e a correta estimativa dos quantitativos e preços dos investimentos, tudo devidamente fundamentado. Esses valores devem ser auditáveis e replicáveis de forma que se possa comprovar a correção da estimativa, o que não se observa no presente caso.

Sobre essa questão, a Lei de Concessões (art. 18, IV e XV, da Lei 8.987/1995) é explícita em exigir que o edital de licitações deva conter, especialmente, estudos e projetos necessários à elaboração dos orçamentos e das propostas, além dos dados relativos à obra, dentre os quais os elementos do projeto básico que permitam sua plena caracterização.

O próprio TCU já se manifestou sobre o tema por meio do item 9.3.3. do Acórdão 851/2009 - Plenário. Determinou ao Banco do Brasil, em processo de Parceria Público Privada, a apresentação dos principais elementos de projeto, assim entendidos: as plantas, detalhes e memórias de cálculo que caracterizam os itens financeiramente mais relevantes do empreendimento, as especificações estratégicas para a prestação dos serviços e as informações essenciais para a elaboração das propostas pelos concorrentes, para a demonstração da eficiência e economicidade da proposta.

Assim sendo, é pertinente determinar à ANTT que corrija e complete o estudo enviado e se abstenha de publicar o edital de licitações até que os problemas estejam sanados, de acordo com as propostas da Unidade Técnica.

Percebo alguns avanços estruturais que tendem a melhorar esses procedimentos de desestatização. A ANTT tem aumentado o quadro de servidores por conta de concursos públicos, as carreiras das agências reguladoras foram fortalecidas, a Secretaria de Acompanhamento Econômico - SEAE foi chamada para colaborar na realização dos cálculos econômicos, entre outros.

Não obstante esses avanços, são necessários outros aperfeiçoamentos para realizar concessões rodoviárias sem riscos adicionais que possam comprometer a modicidade tarifária ou a qualidade da rodovia. 
(cxlvii)Data da sessão: 26/08/2009.

(cxlviii) Relator: Walton Alencar Rodrigues.

(cxlix) Área: desestatização.

(cl) Tema: concessão pública.

(cli) Subtema: revisão tarifária.

(clii) Outros indexadores: equilíbrio econômico-financeiro, clareza, tarifa portuária, regulamentação.

(cliii) Tipo do processo: relatório de auditoria.

(cliv) Enunciado: "a agência reguladora deve estabelecer regras claras para a revisão e o reajuste das tarifas portuárias com base em estudos fundamentados sobre os custos das administrações portuárias, prevendo mecanismos para compartilhar com os usuários os benefícios gerados com possíveis aumentos de eficiência, prezando pela modicidade tarifária e pelo equilíbrio econômico-financeiro das administrações portuárias".

(clv) Objeto: auditoria operacional realizada na Antaq e na SEP com o objetivo de avaliar os entraves à expansão e ao desenvolvimento do setor portuário marítimo.

(clvi) Agência: Antaq.

(clvii) Unidade técnica: Sefid; Secex (estaduais); Secretaria de Fiscalização e Avaliação de Programas de Governo (Seprog).

(clviii) Emissão de comando relacionado à função reguladora? Sim.

(clix) A análise da unidade técnica fiscalizadora foi acolhida pelo relator e pelo Plenário? Parcialmente, porquanto algumas propostas de determinação foram suprimidas.

(clx) Fundamento normativo: arts. 24, XIV, e 27, II, VII e XIV, da Lei ${ }^{\circ}$ 10.233/2011; art. $7^{\circ}, \mathrm{XI}$, do Decreto ${ }^{\circ} 6.620 / 2008$.

(clxi) Precedentes citados: há menção aos Acórdãos 1.926/2004 e $\mathrm{n}^{0} 1.034 / 2008$, do Plenário do TCU, em relação à atuação do Conselho Nacional de Integração de Políticas de Transporte (Coint).

(clxii) Enquadramento: função fiscalizatória, adjudicatória e normatizadora.

(clxiii) Resultado do controle: determinação.

(clxiv) Entendimento do acórdão: trata-se de auditoria operacional voltada ao diagnóstico dos obstáculos à expansão e ao desenvolvimento dos portos marítimos nacionais (gargalo de desenvolvimento), a diagnosticar a atuação da Antaq e da SEP. Para além dos antecedentes históricos, aponta-se a descentralização do setor portuário marítimo, 
mormente pela inexistência de qualquer política portuária nacional, motivo pelo qual as autoridades portuárias atuariam a esmo, de forma marcadamente ineficiente.

ACORDAM os Ministros do Tribunal de Contas da União, reunidos em Sessão do Plenário, diante das razões expostas pelo Relator,

9.1. Com amparo no art. 43, I, da Lei n. ${ }^{\circ} 8.443 / 1992$ c/c o art. 250, II, do Regimento Interno/TCU, determinar:

[...] 9.1.2. à Agência Nacional de Transportes Aquaviários, com fulcro no art. 27, II, VII e XIV, da Lei 10.233/2001, que estabeleça regras claras para a revisão e o reajuste das tarifas portuárias com base em estudos fundamentados sobre os custos das administrações portuárias, prevendo mecanismos para compartilhar com os usuários os benefícios gerados com possíveis aumentos de eficiência, prezando pela modicidade tarifária e pelo equilíbrio econômico-financeiro das administrações portuárias;

9.1.3. à Secretaria Especial de Portos e à Agência Nacional de Transportes Aquaviários, que:

9.1.3.1. conjuntamente, de acordo com as diretrizes do art. $7^{\circ}$, XI, do Decreto 6.620/2008, elaborem e disponibilizem mecanismos regulatórios claros, que levem à implementação de sistemas de preços e tarifas com base em centros de custos e que incentivem a busca da eficiência operacional pelas administrações portuárias;

9.1.3.2. no prazo de 90 dias, apresentem ao TCU plano de ação contendo o cronograma de adoção das medidas necessárias à implementação das deliberações contidas neste Acórdão, com a identificação das respectivas unidades responsáveis.

9.2. Com fulcro no inciso III do art. 250 do RI/TCU, recomendar:

9.2.1. à Agência Nacional de Transportes Aquaviários, que estabeleça prazo para que as autoridades portuárias elaborem e enviem seus PDZs e seus programas de arrendamento atualizados para subsidiar as revisões do Plano Geral de Outorgas, conforme estabelecido no art. 45 do Decreto 6.620/2008;

9.2.2. ao Ministério dos Transportes, que dê início aos trabalhos do Conselho Nacional de Integração das Políticas de Transportes, pela convocação de reuniões do Conselho, com objetivo de estruturar seu regimento interno, constituir comitês técnicos, especificamente no caso do setor portuário, e iniciar o exercício efetivo de suas funções elencadas nos artigos $1^{\circ}, 2^{\circ}$ e 10 do Decreto $6.550 / 2008[\ldots]$.

\section{0) Acórdão 1.201/2009 - Plenário}

(clxv) Data da sessão: 03/06/2009.

(clxvi) Relator: Aroldo Cedraz.

(clxvii)Área: competência do TCU.

(clxviii) Tema: agência reguladora.

(clxix) Subtema: abrangência.

(clxx) Outros indexadores: ilegalidade, determinação, fiscalização.

(clxxi) Tipo do processo: representação.

(clxxii)Enunciado: O poder discricionário conferido aos administradores das agências reguladoras e de qualquer outro ente público não constitui fator impeditivo para o 
exercício das competências do TCU. O Tribunal só deve fazer determinações ou recomendações quando restar comprovada a ilegalidade para fins de determinação, e demonstrada a pertinência técnica das recomendações. Sempre caberá determinação quando configurada a prática de qualquer ilegalidade, seja ela realizada no escopo de um ato de caráter discricionário ou vinculado.

(clxxiii) Objeto: pedido de reexame interposto pela Aneel contra a Decisão $\mathrm{n}^{\mathrm{o}}$ 1.483/2002-Plenário, por meio do qual o tribunal fez determinação e recomendação à autarquia para que corrigisse possíveis erros nos cálculos da revisão tarifária da empresa Espírito Santo Centrais Elétricas S.A. (Escelsa).

(clxxiv) Agência: Aneel.

(clxxv)Unidade técnica: Sefid; Serur.

(clxxvi) Emissão de comando relacionado à função reguladora? Não.

(clxxvii) A análise da unidade técnica fiscalizadora foi acolhida pelo relator e pelo Plenário? Sim, a respeito de a Serur ter proposto o conhecimento do recurso, para, no mérito, negar-lhe provimento, relator e Plenário deram provimento.

(clxxviii) Fundamento normativo: Instrução Normativa nº 43/2002.

(clxxix) Precedentes citados: Acórdão 1.703/2004.

(clxxx)Enquadramento: função adjudicatória e normativa.

(clxxxi) Resultado do controle: desconstituição das determinações constantes da decisão recorrida. Contudo, apenas foi dado provimento ao pedido da Aneel em razão do tempo (sete anos) decorrido entre a autuação da representação e a elaboração do voto do pedido de reexame, sendo que as questões objeto do processo já se encontravam superadas.

(clxxxii) Acórdão: “9.1. conhecer do presente Pedido de Reexame, para, no mérito, dar-lhe provimento; 9.2. tornar insubsistente o item 8.1 e seus subitens e, em consequência, os itens 8.3 e 8.4, todos da Decisão 1.483/2002 - TCU - Plenário;" Contudo, conforme se depreende do trecho de voto do relator a seguir transcrito, apenas foi dado provimento ao pedido da Aneel em razão do tempo (sete anos) decorrido entre a autuação da representação e a elaboração do voto do pedido de reexame, sendo que as questões objeto do processo já haviam sido superadas:

Em razão do tempo decorrido desde que a presente representação foi autuada mais de 7 (sete) anos -, o meu Gabinete fez contatos com a Sefid e foi informado que o presente processo foi o primeiro em que o Tribunal examinou as revisões tarifárias das empresas de distribuição de energia elétrica no Primeiro Ciclo, ocorrido entre os anos de 2003 e 2006. 
26. De acordo com a Sefid, os problemas apontados nestes autos refletiam uma fase incipiente da metodologia adotada pela Aneel e já foram resolvidos, gradualmente, pelo advento de novas metodologias.

27. Dessa forma, as determinações objeto da Decisão recorrida podem ser desconstituídas, uma vez que novos critérios para a revisão tarifária estão sendo adotados pela agência, como informado pela Sefid, contemplando inclusive as orientações deste Tribunal expedidas ao longo do Primeiro Ciclo.

28. Considerando, portanto, que novos critérios para a revisão tarifária estão sendo adotados pela agência, como informado pela Sefid, contemplando inclusive as orientações deste Tribunal, compreendo que o presente recurso deve ser conhecido, para, no mérito, ser concedido a ele provimento, tornando-se insubsistentes as deliberação constantes do item 8.1 e seus subitens e, em consequência, os itens 8.3 e 8.4, todos da Decisão 1.483/2002-TCU-Plenário.

\section{1) Acórdão 1.131/2009 - Plenário}

(clxxxiii) Data da sessão: 27/05/2009.

(clxxxiv) Relator: Aroldo Cedraz.

(clxxxv) Área: competência do TCU.

(clxxxvi) Tema: agência reguladora.

(clxxxvii) Subtema: abrangência.

(clxxxviii) Outros indexadores: ato discricionário, ato vinculado.

(clxxxix) Tipo do processo: relatório de levantamento.

(cxc) Enunciado: quando os atos irregulares praticados pelas agências reguladoras forem vinculados, caberá ao TCU realizar determinações com o objetivo de que sejam corrigidas as irregularidades detectadas. Na hipótese em que os atos são discricionários, o tribunal deve realizar recomendações. Todavia, caso o ato discricionário contenha vício de ilegalidade, a Corte de Contas será competente para avaliá-lo e para determinar a adoção das providências necessárias ao respectivo saneamento, podendo, inclusive, determinar a sua anulação.

(cxci) Objeto: levantamento de auditoria realizado no âmbito do Fiscobras 2008, nas obras de expansão do sistema de trens urbanos de Teresina (PI), executadas pela Companhia Metropolitana de Transporte Público (CMTP). Possibilidade de determinação de prorrogação do Convênio $n^{0}$ 52/2001, relacionado à conclusão das obras de expansão do sistema de trens urbanos de Teresina (PI). Esse caso não entrou na análise pois a entidade analisada não é agência reguladora. O relator apenas traçou paralelo entre o controle dos atos da CMTP e o controle dos atos das agências reguladoras, citando a jurisprudência da Corte sobre o tema. 
(cxcii) Precedentes citados: Acórdãos n ${ }^{\text {os }}$ 1.703/2004, 1.369/2006, 200/2007 e 715/2008, todos do Plenário do TCU.

\section{2) Acórdão 715/2008 - Plenário}

(cxciii)Data da sessão: 23/04/2008.

(cxciv) Relator: Augusto Nardes.

(cxcv) Área: competência do TCU.

(cxcvi) Tema: agência reguladora.

(cxcvii) Subtema: abrangência.

(cxcviii) Outros indexadores: ilegalidade, fiscalização, omissão.

(cxcix) Tipo do processo: representação.

(cc) Enunciado: na fiscalização das atividades-fim das agências reguladoras, o TCU não deve substituir-se aos órgãos que controla, nem estabelecer o conteúdo do ato de competência do órgão regulador, determinando-lhe a adoção de medidas, salvo quando verificar a ocorrência de ilegalidade ou de omissão da autarquia no cumprimento das normas jurídicas pertinentes.

(cci) Objeto: acompanhamento, pela unidade técnica (Sefid), dos atos da ANTT de revisão da metodologia e da data-base do reajuste tarifário dos serviços de Transporte Rodoviário Interestadual de Passageiros (Trip) para percursos superiores a 75 km; definição da periodicidade de procedimentos de revisão.

(ccii) Agência: ANTT.

(cciii) Unidade técnica: Sefid.

(cciv) Emissão de comando relacionado à função reguladora? Não.

(ccv) A análise da unidade técnica fiscalizadora foi acolhida pelo relator e pelo Plenário? Parcialmente (motivos acolhidos, mas, no lugar de determinação, exarou-se recomendação). Novamente, constata-se postura mais intervencionista da unidade técnica.

(ccvi) Fundamento normativo: arts. 21, XII, “e”, da Constituição Federal; 2 $4^{\circ}$, II, §2 11, 12, 20, II, “a”, 22, III, e 24, I e II, da Lei $n^{\circ} 10.233 / 2001 ; 27$ do Decreto $n^{\circ}$ 2.521/1998; 15, I, “l”, 17, IV, 237, V e VI, e 246 do Regimento Interno do TCU.

(ccvii) Precedentes citados: Acórdãos 1.703/2004, 1.926/2004, 2.022/2004, 2.067/2004, 556/2005 e 649/2005, todos do Plenário do TCU. 
(ccviii)Enquadramento: função adjudicatória.

(ccix) Resultado do controle: recomendação.

(ccx) Entendimento do acórdão:

ACORDAM os Ministros do Tribunal de Contas da União, reunidos em Sessão Plenária, ante as razões expostas pelo Relator, em:

9.1. conhecer do presente expediente técnico como Acompanhamento, considerando regulares os procedimentos seguidos pela Agência Nacional de Transportes Terrestres - ANTT - para efetuar os reajustes tarifários do transporte rodoviário interestadual de passageiros em 2005 e 2006, bem como para adotar a Resolução/ANTT n ${ }^{\circ} 1.627$, de 13/9/2006, aprovada na Audiência Pública no 33/2006;

9.2. reafirmar o entendimento deste Plenário segundo o qual, o TCU, na fiscalização das atividades-fim das agências reguladoras, não deve substituir-se aos órgãos que controla, nem estabelecer o conteúdo do ato de competência do órgão regulador, determinando-lhe a adoção de medidas, salvo quando verificar a ocorrência de ilegalidade ou de omissão da autarquia no cumprimento das normas jurídicas pertinentes, conforme Acórdãos 1703/04, 1926/4, 2022/04, 2.067/04, 556/05 e 649/05, todos do Plenário;

9.3. em conseqüência, como contribuição para aprimorar os procedimentos de aplicação da nova fórmula paramétrica de reajuste e revisão da tarifa do transporte rodoviário interestadual de passageiros, prevista na Resolução citada no item 9.1, acima, recomendar à ANTT que, para atender aos objetivos previstos no art. 27 do Decreto 2.521/98, avalie a oportunidade e a conveniência de:

9.3.1. aprimorar os procedimentos de apuração da incidência dos preços do combustível na formação final dos custos das permissionárias;

9.3.2. ampliar a base da amostragem dos modelos e preços de veículos, usada no cálculo do valor médio do custo do ônibus;

9.3.3. ampliar e aprimorar os procedimentos e serviços técnicos de coleta de dados junto às permissionárias, com o objetivo de identificar sempre com maior exatidão os efetivos valores do IAP e do PMA de um conjunto representativo das linhas de serviços convencionais com sanitário;

9.3.4. informar a este Tribunal sobre as medidas adotadas em relação às recomendações acima, com vistas ao aperfeiçoamento dos procedimentos de definição, reajuste e revisão da tarifa dos serviços de transporte rodoviário de passageiros.

9.4. encaminhar cópia do inteiro teor desta deliberação, acompanhada do relatório e do voto que a fundamentam, ao Diretor Geral da ANTT, ao Ministro dos Transportes, à Ministra de Estado Chefe da Casa Civil da Presidência da República, aos Ministros de Estado das Comunicações e do Planejamento, Orçamento e Gestão, aos Presidentes das Comissões de Defesa do Consumidor, de Fiscalização e Controle do Senado Federal e da Câmara dos Deputados, ao Deputado Federal Leonardo Picciani, ao Diretor do Departamento de Proteção e Defesa do Consumidor do Ministério da Justiça, ao Coordenador da $3^{\mathrm{a}}$ Câmara de Coordenação e Revisão do Ministério Público Federal, bem assim ao Secretário da SEAE/MF e ao Presidente da ABRATI

9.5. determinar que a Sefid acompanhe a implementação, no âmbito do Poder Executivo, da Resolução/ANTT no 1.627 , de 13/9/2006 e a eventual modificação de seus dispositivos, com observância da orientação contida no item 9.2, acima.

\section{3) Acórdão 620/2008 - Plenário}


(ccxi) Data da sessão: 11/03/2008.

(ccxii) Relator: Benjamin Zymler.

(ccxiii)Área: competência do TCU.

(ccxiv) Tema: agência reguladora.

(ccxv) Subtema: abrangência.

(ccxvi) Outros indexadores: ato ilegal, atividade-fim, fiscalização.

(ccxvii) Tipo do processo: denúncia.

(ccxviii) Enunciado: "o controle exercido pelo Tribunal de Contas da União sobre a área-fím das agências reguladoras deve ser um controle de segunda ordem, vocacionado para exarar determinações apenas quando for constatada a prática de atos ilegais."

(ccxix)Objeto: trata-se de denúncia relacionada à autorização da Aneel para que a Companhia Energética de São Paulo (Cesp) venda energia elétrica em montantes e prazos que sobejam a vigência dos seus atuais contratos de concessão.

(ccxx) Agência: Aneel.

(ccxxi) Unidade técnica: Sefid.

(ccxxii) Emissão de comando relacionado à função reguladora? Não.

(ccxxiii) A análise da unidade técnica fiscalizadora foi acolhida pelo relator e pelo Plenário? Não.

(ccxxiv) Fundamento normativo: Decretos $n^{\circ} 5.163 / 2004$ e $n^{\circ} 5.271 / 2004$.

(ccxxv) Precedentes citados: não há precedentes citados, divisando-se apenas a improcedência da denúncia.

(ccxxvi) Enquadramento: atividade fiscalizatória.

(ccxxvii) Resultado do controle: ausência de reverberação na função regulatória.

(ccxxviii) Entendimento do acórdão: embora assentado que a denúncia preenchia os requisitos de admissibilidade (artigo 53 da Lei $n^{\circ} 8.443 / 92$ e artigos 234 e 235 do Regimento Interno do TCU), foi reputada improcedente, porquanto não há vedação legal para que a CESP celebrasse promessa de venda de energia elétrica para períodos que superem os prazos da sua concessão, firmada junto à União, por intermédio da ANEEL. Reforçou-se o entendimento de que a atuação do TCU perante as atividadesfim das agências reguladoras só é legítima diante de atos ilegais (vinculados), vez que àquelas há garantia de atuação discricionária. Daí o indeferimento da medida cautelar requerida (para a suspensão das vendas) e o juízo de improcedência da denúncia. 
irregularidade veiculada nesta denúncia não subsiste. A uma, porque o art. $27, \S$ $2^{\circ}$, do Decreto $n^{\circ} 5.163$, de 30/07/2004, que vedava a contratação no âmbito do ambiente regulado em prazos superiores àquele estipulado para a concessão foi revogado pelo Decreto n. ${ }^{0}$ 5.271, de 16/11/2004. A duas, porque não há restrição legal para o registro na Aneel de contratos celebrados no mercado livre que contenham promessa de venda de energia abrangendo período posterior ao de validade do contrato de concessão relativo à geração. A três, porque a inexistência de vedação legal à autorização em tela permite que a Aneel adote decisões discricionárias sobre a matéria, o que afasta, em tese, a competência do TCU para determinar a revisão dessas decisões. Afinal, o controle exercido pelo Tribunal de Contas da União sobre a área-fim das agências reguladoras deve ser um controle de segunda ordem, vocacionado para exarar determinações apenas quando for constatada a prática de atos ilegais. Por último, deve-se sopesar que as autorizações emitidas pela Aneel visam conferir mais eficácia ao mercado de compra e venda de energia, uma vez que, conforme registrado pela unidade técnica, a obrigação de coincidência da vigência de um contrato de comercialização de energia com a duração de um contrato de concessão de geração esbarra em diversas dificuldades práticas, tais como, por exemplo, um eventual atraso em uma licitação da concessão interromperia a disponibilidade de energia para o mercado.

Acórdão:

VISTOS, relatados e discutidos estes autos que tratam de denúncia versando sobre autorização da Aneel para que a Companhia Energética de São Paulo CESP venda energia para comercializadores e consumidores livres em montantes e prazos que ultrapassam o prazo de vigência dos atuais contratos de concessão.

ACORDAM os Ministros do Tribunal de Contas da União, reunidos em Sessão do Plenário, ante as razões expostas pelo Relator, em:

9.1. indeferir o presente pedido de cautelar ante a inexistência do periculum in mora e do fumus boni juris;

9.2. conhecer da presente denúncia, para, no mérito, julgá-la improcedente, com fulcro no art. 53 da Lei Orgânica do TCU e nos arts. 234 e 235 do Regimento Interno desta Corte de Contas;

9.3. levantar a chancela de sigilo aposta a estes autos;

9.4. dar ciência deste Acórdão, bem como do Relatório e do Voto que o fundamentaram, ao denunciante e à Agência Nacional de Energia Elétrica Aneel.

\section{4) Acórdão 602/2008 - Plenário}

(ccxxix) Data da sessão: 11/03/2008.

(ccxx) Relator: Benjamin Zymler.

(ccxxxi) Área: competência do TCU.

(ccxxxii) Tema: agência reguladora.

(ccxxxiii) Subtema: abrangência.

(ccxxxiv) Outros indexadores: fiscalização, ato discricionário, vício.

(ccxxxv) Tipo do processo: acompanhamento. 
(ccxxxvi) Enunciado: "o controle do TCU sobre os atos de regulação é de segunda ordem, na medida que o limite a ele imposto esbarra na esfera de discricionariedade conferida ao ente regulador. No caso de ato discricionário praticado de forma motivada e em prol do interesse público, cabe ao TCU, tão somente, recomendar a adoção das providências que reputar adequadas. Não é suprimida a competência do tribunal para determinar medidas corretivas a ato praticado na esfera de discricionariedade das agências reguladoras, desde que viciado em seus atributos, a exemplo da competência, da forma, da finalidade ou, ainda, inexistente o motivo determinante e declarado. Em tais hipóteses, e se a irregularidade for grave, pode até mesmo determinar a anulação do ato".

(ccxxxvii) Objeto: acompanhamento do Leilão $n^{\circ}$ 005/2008, destinado à contratação de energia proveniente do Complexo do Rio Madeira, mediante construção da Usina Hidroelétrica de Jirau, com posterior outorga de Concessão de Uso de Bem Público destinada à exploração e ao aproveitamento hidrelétrico, para o Sistema Interligado Nacional (SIN), no Ambiente de Contratação Regulada (ACR).

(ccxxxviii) Agência: Aneel.

(ccxxxix) Unidade técnica: Sefid, Secob e $4^{\mathrm{a}}$ Secex.

(ccxl) Emissão de comando relacionado à função reguladora? Sim.

(ccxli) A análise da unidade técnica fiscalizadora foi acolhida pelo relator e pelo Plenário?

Parcialmente. A proposta da Secob foi no sentido de

determinar à ANEEL que, nas futuras licitações de concessão de aproveitamentos hidrelétricos, haja, obrigatoriamente, orçamento detalhado do custo global da obra, fundamentado em quantitativos de serviços e fornecimentos propriamente avaliados, contendo as especificações técnicas dos serviços de obras civis e dos equipamentos eletromecânicos, bem como as correspondentes composições de custos unitários. (grifo nosso).

A partir de entendimento proferido pelo relator, essa determinação e outras, dirigidas à Empresa de Pesquisa Energética (EPE) e ao Ministério de Minas e Energia (MME), adotaram a forma de recomendações:

17.Sem embargo de reconhecer que as orientações advindas das análises técnicas efetivadas pelo Tribunal contribuem para as agências reguladoras pautarem-se dentro dos princípios constitucionais da legalidade e da eficiência, enfatizo que o controle do TCU é de segunda ordem, na medida que o limite a ele imposto esbarra na esfera de discricionariedade conferida ao ente regulador.

18.A partir desta premissa, verificada qualquer violação de disposição legal expressa, em ato vinculado, poderá o Tribunal determinar ao agente regulador que adote medidas tendentes ao saneamento do ato tido por irregular. Já, no caso 
de ato discricionário, praticado de forma motivada e em prol do interesse público, cabe a esta Corte, tão-somente, recomendar a adoção das providências que reputar adequadas.

19.Não se suprime, contudo, a competência do TCU para determinar medidas corretivas a ato praticado na esfera de discricionariedade das agências reguladoras, desde que este sido "praticado por autoridade incompetente, se não tiver sido observada a forma devida, se o motivo determinante e declarado de sua prática não existir ou, ainda, se estiver configurado desvio de finalidade", conforme asseverei no Voto Revisor que apresentei no TC - 016.128/2003-2. Em tal hipótese, poderá o Tribunal até mesmo determinar a anulação do ato, se grave for a irregularidade perpetrada.

20.No processo que ora se examina, conforme deflui das instruções compiladas no Relatório que faço preceder este Voto, não se verifica qualquer um dos pressupostos à atuação repressiva do Tribunal, no âmbito discricionário da ANEEL, e também do Ministério das Minas e Energia e Empresa de Pesquisa Energética. Inexistiram indícios de atos eivados de ilegalidade ou praticados por agente incompetente.

Portanto, em se tratando de fase interna da licitação a se realizar pelo Leilão $\mathrm{n}^{0}$ $005 / 2008$, as medidas alvitradas na manifestação consolidada da SEFID $/ 4^{\mathrm{a}}$ SECEX/SECOB, ainda que tendentes a reduzir o preço-teto do certame, devem se revestir sob a forma de recomendações, restando aos seus destinatários a implementação daquelas que entender oportunas e convenientes. (Voto do relator).

(ccxlii)Fundamento normativo: art. 17 da Instrução Normativa TCU nº 27/1998 e tendo em conta a necessidade de atuação preventiva do TCU, a fim de resguardar o erário, os consumidores de energia elétrica e o interesse público, submetemos os autos à consideração superior propondo, com fulcro no art. $6^{\circ}, \S 1^{\circ}$, da Lei $n^{\circ} 8.987 / 1995$, e no art. 2º, I, da Lei n ${ }^{\circ} 10.848 / 2004$, ao tribunal. Resolução TCU nº 199/2006, a respeito da unidade técnica para a avaliação de outorga de obras e serviços públicos e de atividades econômicas dos setores de infraestrutura, assim como o acompanhamento da execução dos respectivos contratos.

(ccxliii) Precedentes citados: TC 016.128/2003-2.

(ccxliv) Enquadramento: função adjudicatória.

(ccxlv) Resultado do controle: recomendação.

(ccxlvi) Entendimento do acórdão:

Acórdão:

9.3. recomendar à ANEEL que, em futuras licitações de concessão de aproveitamentos hidrelétricos, faça constar dos editais correspondentes o orçamento detalhado do custo global da obra, fundamentado em quantitativos de serviços e fornecimentos propriamente avaliados, contendo as especificações técnicas dos serviços de obras civis e dos equipamentos eletromecânicos, bem como as correspondentes composições de custos unitários. 
(ccxlvii) Data da sessão:10/10/2007.

(ccxlviii) Relator: Benjamin Zymler.

(ccxlix) Área: competência do TCU.

(ccl) Tema: agência reguladora.

(ccli) Subtema: abrangência.

(cclii) Outros indexadores: fiscalização.

(ccliii) Tipo do processo: acompanhamento.

(ccliv) Enunciado: no que tange ao acompanhamento de outorgas ou execução contratual de serviços públicos concedidos, a fisscalização exercida pelo TCU, nas atividades regulatórias, possui caráter de ancilaridade ao Poder Concedente. Trata-se de um controle de segunda ordem, cujos limites se estabelecem na esfera de discricionariedade conferida ao agente regulador.

(cclv) Objeto: "acompanhamento destinado à contratação de energia proveniente do Complexo do Rio Madeira, mediante construção da Usina Hidroelétrica de Santo Antônio, com posterior outorga de Concessão de Uso de Bem Público destinada à exploração e ao aproveitamento hidrelétrico, para o Sistema Interligado Nacional, no Ambiente de Contratação Regulada".

(cclvi) Agência: Aneel.

(cclvii)Unidade técnica: Secob; Sefic, Secex.

(cclviii) Emissão de comando relacionado à atividade-fim da Agência? Sim.

(cclix) A análise da unidade técnica fiscalizadora foi acolhida pelo relator e pelo Plenário?

Parcialmente, na medida em que se alterou a determinação por recomendação, reconhecendo se tratar de ato discricionário.

(cclx) Fundamento normativo: arts. 37 e 175 da Constituição Federal; Lei no 8.987/1995; Instrução Normativa TCU no 27/1998.

(cclxi) Precedentes citados: não há precedentes citados.

(cclxii)Enquadramento: função adjudicatória.

(cclxiii) Resultado do controle: recomendação.

(cclxiv) Entendimento do acórdão: ainda que reconheça o acerto das conclusões atingidas pelas unidades técnicas, o TCU reputou que os índices econômicos, financeiros e contábeis que embasaram o Leilão $n^{\circ}$ 005/2007 estariam insertos no âmbito da discricionariedade técnica da agência reguladora. 


\section{6) Acórdão 632/2007 - Plenário}

(cclxv) Data da sessão: 18/04/2007.

(cclxvi) Relator: Augusto Nardes.

(cclxvii) Área: competência do TCU.

(cclxviii) Tema: agência reguladora.

(cclxix) Subtema: abrangência.

(cclxx) Outros indexadores: fiscalização.

(cclxxi) Tipo do processo: solicitação do Congresso Nacional.

(cclxxii) Enunciado: “compete às agências criadas para o acompanhamento das atividades sujeitas a regulação pública resolverem autonomamente os problemas detectados em suas respectivas áreas de atuação. Cabe ao TCU o controle indireto do setor, voltado exclusivamente para a atuação do órgão regulador, sem prejuízo da responsabilização direta dos administradores do órgão ou entidade regulada que, exorbitando do controle e supervisão da agência competente, ou à sua revelia, tenham praticado irregularidade afeta a matéria de competência do Tribunal."

(cclxxiii) Objeto: solicitação da Comissão de Agricultura, Pecuária, Abastecimento e Desenvolvimento Rural da Câmara dos Deputados para realização de fiscalização complementar pelo TCU sobre a Administração dos Portos de Paranaguá e Antonina (Appa), "que estaria descumprindo o convênio de delegação 37/2001, celebrado entre a União e o Governo do Estado do Paraná, mediante o qual foi delegada àquela Unidade Federada a administração dos referidos portos federais".

(cclxxiv) Agência: Antaq.

(cclxxv) Unidade técnica: Sefid.

(cclxxvi) Emissão de comando relacionado à função reguladora? Sim.

(cclxxvii) A análise da unidade técnica fiscalizadora foi acolhida pelo relator e pelo Plenário? Sim.

(cclxxviii) Fundamento normativo: art. 43, II, da Lei $\mathrm{n}^{\circ}$ 8.443/1992, c/c o art. 250, IV, do Regimento Interno do TCU; art. 58 da Lei $\mathrm{n}^{\mathrm{o}}$ 8.443/1992; art. 11 da Lei $\mathrm{n}^{\mathrm{o}}$ $8.443 / 1992$.

(cclxxix) Precedentes citados: Acórdão 768/2005-Plenário.

(cclxxx) Enquadramento: atividade adjudicatória e fiscalizatória. 
(cclxxxi) Resultado do controle: determinação a representante de entidade regulada (superintendente da Administração dos Portos de Paranaguá e Antonina).

(cclxxxii) Entendimento do acórdão: o Plenário determinou, com fundamento no art. 43, II, da Lei $\mathrm{n}^{\mathrm{o}} 8.443 / 1992$, c/c o art. 250, IV, do Regimento Interno do TCU, a audiência do Sr. Eduardo Requião de Mello e Silva, superintendente da Appa, para que, no prazo de quinze dias, apresentasse razões de justificativa acerca das ocorrências que estariam em desacordo com a legislação aplicável e com as condições pactuadas no Convênio de Delegação $n^{0} 37 / 2001$, celebrado entre a União federal e o governo do estado do Paraná.

\section{7) Acórdão 200/2007 - Plenário}

(cclxxxiii) Data da sessão: 28/02/2007.

(cclxxxiv) Relator: Valmir Campelo.

(cclxxxv) Área: competência do TCU.

(cclxxxvi) Tema: agência reguladora.

(cclxxxvii) Subtema: abrangência.

(cclxxxviii) Outros indexadores: fiscalização, recomendação.

(cclxxxix) Tipo do processo: desestatização.

(ccxc) Enunciado: “em se tratando de atos discricionários de agência reguladora, o TCU se limita a recomendar a adoção de providências consideradas por ele mais adequadas." (ccxci) Objeto: pedidos de reexame de acompanhamento do processo de revisão tarifária periódica referente aos serviços públicos de distribuição de energia elétrica concedidos à Companhia Energética do Estado de Minas Gerais (Cemig), iniciado em 2003, consoante as disposições da Instrução Normativa TCU n ${ }^{\circ} 43 / 2002$. (Processo de revisão tarifária periódica cobrada pela Cemig e efeitos da distribuição de juros sobre capital próprio.)

(ccxcii) Agência: Aneel.

(ccxciii) Unidade técnica: Sefid; Serur.

(ccxciv) Emissão de comando relacionado à atividade-fim da agência? Sim.

(ccxcv) A análise da unidade técnica fiscalizadora foi acolhida pelo relator e pelo Plenário? Não. 
(ccxcvi) Fundamento normativo: arts. 11, parágrafo único, e 18, VI, da Lei $\mathrm{n}^{\mathrm{o}}$ 8.987/1995; art. 250, III, do Regimento Interno do TCU; Instrução Normativa TCU n ${ }^{\circ}$ 43/2002.

(ccxcvii) Precedentes citados: Acórdãos n ${ }^{\text {os }} 1.756 / 2004$ e 1.757/2004, do Plenário do TCU.

(ccxcviii) Enquadramento: função adjudicatória/normativa.

(ccxcix) Resultado do controle: recomendações e determinações.

(ccc) Entendimento do acórdão:

A consideração dos efeitos de destruição de juros sobre capital próprio e seu impacto na revisão periódica do valor de tarifas é de competência da ANEEL, a traduzir exercício de competência discricionária. Nessa linha, ao TCU só é possível exarar recomendações.

$[\ldots]$

2.Quanto ao mérito, observo do acima relatado que se insere na competência da ANEEL decidir discricionariamente sobre a consideração dos efeitos da distribuição de juros sobre o capital próprio no cálculo do reposicionamento das tarifas cobradas pelas concessionárias de distribuição de energia elétrica.

3.Destaco que essa competência já foi reconhecida pelo Plenário deste Tribunal ao deliberar acerca dos Embargos de Declaração opostos aos Acórdãos n. $1.756 / 2004$ e $1.757 / 2004$, proferidos nos processos TC-007.371/2003-5 e TC016.128/2003-2, de acordo com o voto condutor apresentado pelo Ministro Benjamin Zymler.

4.Naquela assentada, esta Corte de Contas decidiu "recomendar à Aneel que, no estudo específico que aquela agência vem conduzindo no contexto do processo de revisão tarifária periódica, avalie a oportunidade, a conveniência e a forma mais adequada de consideração dos efeitos do benefício fiscal decorrente da distribuição de juros sobre o capital próprio, na forma prevista na Lei $\mathrm{n}^{0}$ 9.249/1995", e firmou entendimento no sentido de que:

a) se $\mathrm{o}$ ato for de natureza discricionária, cabe ao Tribunal expedir recomendações;

b) se o ato for de natureza vinculada, cabe ao Tribunal expedir determinações.

5.Com base nessas razões, acolho em parte os argumentos apresentados pela ANEEL e pela CEMIG e julgo ser conveniente transformar a determinação constante do subitem 9.1.1.2 do Acórdão recorrido em recomendação. (grifos nossos).

ACORDAM os Ministros do Tribunal de Contas da União, reunidos em Sessão do Plenário, diante das razões expostas pelo Relator, com fundamento no art. 48, parágrafo único, da Lei n. $.^{\circ} 8.443 / 92$ c/c o art. 286 do Regimento Interno/TCU, em:

9.1. conhecer dos presentes Pedidos de Reexame interpostos pela Agência Nacional de Energia Elétrica e pela Companhia Energética de Minas Gerais, para, no mérito, dar-lhes provimento parcial, e em consequência tornar insubsistente o Acórdão n. 1.756/2003-TCU-Plenário;

9.2. com fundamento no art. 250, inciso III, do Regimento Interno, determinar à ANEEL que:

9.2.1. no processo de revisão tarifária periódica da Cemig previsto para ocorrer em abril de 2008, caso ainda não tenha corrigido, considere os efeitos decorrentes da utilização do valor das receitas de uso do sistema de distribuição, que constou de item autônomo e também compôs o item Outras Receitas, retroagindo esses efeitos a data de homologação da revisão tarifária de 2003; 
9.2.2. nos próximos processos de revisão tarifária:

9.2.2.1. observe os arts. $2^{\circ}$ e 50 da Lei 9.784/1999, no que se refere à motivação dos atos administrativos, divulgando tempestivamente em cada revisão tarifária os motivos pelos quais aceitou ou rejeitou os pleitos dos participantes da audiência pública;

9.2.2.2. divulgue as revisões tarifárias com a antecedência necessária de modo a permitir que haja um intervalo maior entre a publicação das notas técnicas e a realização das audiências públicas;

9.3. recomendar à ANEEL que:

9.3.1. no estudo específico que vem conduzindo no contexto do processo de revisão tarifária periódica, avalie a oportunidade, a conveniência e a forma mais adequada de consideração dos efeitos do benefício físcal decorrente da distribuição de juros sobre o capital próprio, na forma prevista na Lei $\mathrm{n}^{\mathrm{o}}$ 9.249/1995;

9.3.2. defina previamente o valor da base de remuneração a ser utilizado na revisão periódica;

9.3.3. adote critério objetivo para calcular o percentual da receita extraconcessão que será considerado para efeito de modicidade tarifária;

9.4. encaminhar cópia desta deliberação, acompanhada do relatório e voto que a fundamentam:

9.4.1. ao Ministro de Estado de Minas e Energia;

9.4.2. ao Conselho Nacional de Política Energética - CNPE;

9.4.3. às Comissões de Fiscalização e Controle e de Serviços de Infra-estrutura do Senado Federal;

9.4.4. às Comissões de Minas e Energia e de Fiscalização e Controle da Câmara dos Deputados;

9.4.5. à Agência Nacional de Energia Elétrica e à Companhia Energética de Minas Gerais;

9.4.6. ao Ministério Público Federal, Procuradoria da República em Minas Gerais, por intermédio de seu ilustre representante, Procurador da República Fernando de Almeida Martins.

\section{8) Acórdão 1.369/2006 - Plenário}

(ccci) Data da sessão: 09/08/2006.

(cccii) Relator: Valmir Campelo.

(ccciii) Área: competência do TCU.

(ccciv) Tema: agência reguladora.

(cccv) Subtema: abrangência.

(cccvi) Outros indexadores: fiscalização, ato vinculado, determinação.

(cccvii) Tipo do processo: relatório de auditoria.

(cccviii) Enunciado: "o TCU tem competência para emitir determinações à agência reguladora, tratando-se de matérias às quais a entidade está vinculada por disposições legais expressas ou inferidas a partir de interpretação sistemática do ordenamento jurídico. A atuação do TCU deve se dar de forma complementar à ação 
das entidades reguladoras no que concerne ao acompanhamento da outorga e da execução contratual dos serviços concedidos.”

(cccix) Objeto: pedidos de reexame interpostos pela ANTT, Associação Brasileira das Empresas de Transporte Terrestre de Passageiros (Abrati), Auto Viação Catarinense Ltda. e Viação Cometa S/A contra o Acórdão 1.926/2004-TCU-Plenário (auditoria operacional realizada para avaliar a regulação dos serviços públicos relativos ao transporte rodoviário internacional e interestadual de passageiros).

(cccx) Agência: ANTT.

(cccxi) Unidade técnica: Serur.

(cccxii) Emissão de comando relacionado à função reguladora? Sim.

(cccxiii) A análise da unidade técnica fiscalizadora foi acolhida pelo relator e pelo Plenário? Parcialmente, na medida em que se substituíram algumas determinações por recomendações.

(cccxiv) Fundamento normativo: Lei $\mathrm{n}^{\mathrm{o}}$ 8.987/1995; Lei $\mathrm{n}^{\mathrm{o}}$ 9.074/1995; Lei $\mathrm{n}^{\mathrm{o}}$ 10.233/2001; Decreto $n^{0}$ 2.521/1998.

(cccxv) Precedentes citados: Acórdão 1.703/2004-TCU-Plenário (usado para afastar a aplicabilidade dos argumentos apresentados no acórdão ora em análise — promoção do distinguish).

(cccxvi) Enquadramento: função normativa, função fiscalizatória.

(cccxvii) Resultado do controle: recomendações e determinações.

(cccxviii) Entendimento do acórdão: parcela das determinações foram convoladas em recomendações; contudo, foram mantidas determinações em relação à atividade regulatória da ANTT, ao argumento de que se está diante do cumprimento de obrigações sediadas em lei.

\section{9) Acórdão 649/2005 - Plenário}

(cccxix) Data da sessão: 25/05/2005.

(cccx) Relator: Walton Alencar Rodrigues.

(cccxxi) Área: desestatização.

(cccxxii) Tema: concessão pública.

(cccxxiii) Subtema: revisão tarifária.

(cccxxiv) Outros indexadores: concessionária, transmissão de energia elétrica, receita. 
(cccxxv) Tipo do processo: desestatização.

(cccxxvi) Enunciado: "a Agência Reguladora de serviços de transmissão de energia elétrica deve regulamentar a revisão do valor da receita anual permitida, visando contribuir para a modicidade tarifária do serviço público de transmissão, em razão de receita auferida com outras atividades (Lei 8.987/1995, art. 11).”

(cccxxvii) Objeto: trata-se de acompanhamento do processo de licitação para outorga de concessões para prestação do serviço público de transmissão de energia elétrica, incluindo a construção, a operação e a manutenção de instalações de transmissão de energia elétrica integradas à Rede Básica do Sistema Interligado Nacional, referente ao Edital de Leilão Aneel no 001/2004.

(cccxxviii) Agência: Aneel.

(cccxxix) Unidade técnica: Sefid.

( $\operatorname{cccxxx})$ Emissão de comando relacionado à função reguladora? Sim.

(cccxxxi) A análise da unidade técnica fiscalizadora foi acolhida pelo relator e pelo Plenário? A Sefid determinou:

em face do princípio da transparência, reiteramos determinação constante da Decisão TCU n. ${ }^{\circ}$ 361/2001 - Plenário, item 8.2, no sentido de que a ANEEL faça constar, dos atos justificatórios das futuras licitações de concessão de linhas de transmissão, a metodologia e a memória de cálculo empregadas para obter os coeficientes de ponderação da variação cambial e do IGP-M utilizados para atualizar os custos modulares de referência da ELETROBRÁS, sob pena de multa prevista no Art. 58, $\S 1^{\circ}$ da Lei n. ${ }^{\circ} 8.443 / 92$ c/c Art. 268, VII e $\S 3^{\circ}$ do Regimento Interno do TCU[, sendo] necessário que a ANEEL corrija a variação do IGP-M utilizada nas planilhas de cálculo do investimento e atente para a utilização correta desse índice nas planilhas de cálculo das futuras licitações de concessão de linha de transmissão.

Além disso, a unidade técnica entendeu que a "revisão tarifária periódica das tarifas de transmissão de energia elétrica é imprescindível para manter as condições de equilíbrio econômico-financeiro", determinando a inclusão de cláusula nos contratos de concessão referente a essas revisões. O ministro relator não concordou com a imprescindibilidade da revisão tarifária periódica, apesar de seguir parcialmente o entendimento manifestado pela Sefid ao aduzir que

os erros e omissões apurados são graves e robustecem a necessidade de atuação tempestiva do controle externo da atividade-fim dos órgãos reguladores. Acolho as determinações e recomendações sugeridas pela unidade técnica visando a evitar repetição das falhas apuradas. 
O posicionamento do ministro Walton Alencar Rodrigues foi referendado pelo Plenário da Corte de Contas.

(cccxxxii) Fundamento normativo: arts. 18, da Lei $n^{\circ} 10.438 / 2002$, e 14, IV, da Lei ${ }^{\circ}$ $9.427 / 1996$.

(cccxxxiii) Precedentes citados: Decisão $n^{0}$ 361/2001-TCU-Plenário; Decisão $n^{0}$ 300/2001-TCU-Plenário; Decisão n n 958/1999-Plenário; Acórdãos 1.703/2004, 1.926/2004, 2.022/2004 e 2.067/2004, todos proferidos pelo Plenário.

(cccxxxiv) Enquadramento: função adjudicatória e normativa.

(cccxxv) Resultado do controle: determinação e recomendação.

(cccxxxvi) Entendimento do acórdão: o Plenário do TCU seguiu o posicionamento adotado pelo ministro relator, o qual decidiu que

\begin{abstract}
Não há, portanto, cláusula contratual que permita assegurar o fiel cumprimento à lei (apropriação de ganhos de eficiência) e não há como dar efetividade à disposição contratual atinente à modicidade tarifária[, sendo que] não pode a agência afastar do regime econômico financeiro a ser estabelecido nessas concessões a apropriação dos ganhos de eficiência. Não pode, portanto, deixar de incluir nos contratos as condições para a realização de reajustes e revisões que permitam essa apropriação.
\end{abstract}

Ademais, recomendou-se que a Sefid promovesse uma diligência para que a Aneel apresentasse justificativas referentes à ausência de mecanismos de revisão tarifária periódica.

\title{
30) Acórdão 1.926/2004 - Plenário
}

(cccxxxvii) Data da sessão: 01/12/2004.

(cccxxxviii) Relator: Adylson Motta.

(cccxxxix) Área: desestatização.

(cccxl) Tema: concessão pública.

(cccxli) Subtema: revisão tarifária.

(cccxlii) Outros indexadores: concessionária, transporte internacional, transporte interestadual, receita, transporte rodoviário.

(cccxliii) Tipo do processo: relatório de auditoria.

(cccxliv) Enunciado: "Devem constar nos editais das licitações para concessão de serviços de transporte rodoviário interestadual e internacional de passageiros, as 
possíveis fontes de receitas alternativas, complementares ou acessórias, bem como as provenientes de projetos associados (art. 18, VI, Lei 8.987/1995). Para os contratos em vigor, a Agência Reguladora deve identificar, entre as atividades econômicas exploradas pelas permissionárias, as que se enquadram no conceito constante do art. 11 da Lei 8.987/1995, a fim de apurar as possíveis receitas alternativas, complementares, acessórias ou de projetos associados e revertê-las à modicidade tarifária, aditando, conforme o caso, os referidos contratos."

(cccxlv) Agência: ANTT.

(cccxlvi) Unidade técnica: Sefid.

(cccxlvii) Emissão de comando relacionado à função reguladora? Sim.

(cccxlviii) A análise da unidade técnica fiscalizadora foi acolhida pelo relator e pelo Plenário? Sim. A Sefid identificou que

\begin{abstract}
o modelo atual de remuneração por custos não internaliza pelo menos parte dos ganhos de produtividade, de receitas alternativas, complementares, acessórias ou de projetos associados, com o intuito de favorecer a modicidade tarifária, conforme previsto no art. 11 da Lei no 8.987/95[, além de ressaltar a] atribuição da ANTT elaborar e editar normas e regulamentos relativos à exploração de vias e terminais, garantindo isonomia no seu acesso e uso, bem como à prestação de serviços de transporte, mantendo os itinerários outorgados e fomentando a competição.
\end{abstract}

O ministro relator acolheu integralmente as propostas elaboradas pela unidade técnica, assim como o Plenário do Tribunal de Contas da União.

(cccxlix) Fundamento normativo: art. 24, III, da Lei ${ }^{\circ} 10.233 / 2001$; art. 18, VI, da Lei nº 8.987/1995; Resolução ANTT nº 233/2003.

(cccl) Precedentes citados: declaração de voto proferido na Sessão Plenária de 03/11/2004 (TC 006.931/2002, Ata n ${ }^{\circ}$ 41/2004 referente ao Acórdão 1.703/2004-Plenário).

(cccli) Enquadramento: função adjudicatória e normativa.

(ccclii)Resultado do controle: determinação e recomendação.

(cccliii) Entendimento do acórdão: o ministro relator, acolhendo integralmente as recomendações e as determinações propostas pela Sefid, entendeu que

verificou-se que, não obstante a existência de dispositivos legais nesse sentido, a Agência Nacional de Transportes Terrestres - ANTT e demais órgãos responsáveis dão pouca ênfase ao conhecimento do perfil da demanda e à participação do usuário nos processos decisórios.

Dentre elas, determinou-se que a ANTT 
reveja a redação dada ao inciso II do $\S 3^{\circ}$ do art. 15 da Resolução ANTT $n^{\circ}$ 18/2002 de forma a não restringir a participação no processo licitatório de interessados que, apesar de não prestarem serviço de transporte de passageiros, comprovem a disponibilidade de quadro profissional apto para a prestação do serviço, pois tal dispositivo, na forma que consta no citado normativo, restringe a concorrência no certame licitatório e promove a concentração do setor.

\section{1) Acórdão 1.757/2004 - Plenário}

(cccliv) Data da sessão: 10/11/2004.

(ccclv) Revisor: Benjamin Zymler.

(ccclvi) Área: competência do TCU.

(ccclvii) Tema: agência reguladora.

(ccclviii) Subtema: abrangência.

(ccclix) Outros indexadores: fiscalização.

(ccclx) Tipo do processo: desestatização.

(ccclxi) Enunciado: “o TCU possui competência para fiscalizar as atividades finalísticas das agências reguladoras, devendo atuar de forma complementar à ação dessas entidades no que concerne ao acompanhamento da outorga e da execução contratual dos serviços concedidos."

(ccclxii) Objeto: embargos de declaração opostos pelo Sr. José Mário de Miranda Abdo, diretor-presidente da Aneel, contra o item 9.1 e subitens do Acórdão 556/2004Plenário, a seguir transcritos.

9.1. determinar à Aneel que: 9.1.1 adote as providências necessárias para incluir, no cálculo do reposicionamento tarifário da LIGHT, ocorrido em 2003, os efeitos do benefício fiscal previsto na Lei $n^{\circ}$ 9.249/95, decorrentes da distribuição aos acionistas de juros sobre o capital próprio; 9.1.2 inclua, nos próximos processos de revisão tarifária, os efeitos do benefício fiscal previsto na Lei $\mathrm{n}^{\circ}$ 9.249/95, decorrentes da distribuição aos acionistas de juros sobre o capital próprio; $[\ldots]$.

O embargante alegou que o acórdão impugnado incorreu em omissão "ao não considerar que a ANEEL ainda desenvolve estudo com vistas a tomar uma decisão quanto ao benefício fiscal dentro do processo de revisão tarifária periódica, no contexto da regulação por incentivos". Alegou, ainda, a existência de omissão, quanto ao exame do "contexto global do processo regulatório, em que a modicidade tarifária foi extensivamente contemplada". 
(ccclxiii) Agência: Aneel.

(ccclxiv) Unidade técnica: Sefid.

(ccclxv) Emissão de comando relacionado à função reguladora? Sim.

(ccclxvi) A análise da unidade técnica fiscalizadora foi acolhida pelo relator e pelo Plenário? Não; nem pelo revisor, nem pelo Plenário.

(ccclxvii) Fundamento normativo: Instrução Normativa $n^{\circ} 43 / 2002$; art. $6^{\circ}$ da Lei $n^{0}$ 8.987/1995; art. $7^{0^{438}}$ da Lei n ${ }^{\circ}$ 9.427/1996; art. 71, IV, da Constituição Federal.

(ccclxviii) Precedentes citados: Não há precedentes citados.

(ccclxix) Enquadramento: função adjudicatória/normativa (referente à Resolução Aneel no 323/2003).

(ccclxx) Resultado do controle: recomendação (mudança da natureza da decisão, de determinação para recomendação).

(ccclxxi) Entendimento do acórdão: foram conhecidos e providos os embargos de declaração:

9.2. recomendar à Aneel que, no estudo específico que aquela agência vem conduzindo no contexto do processo de revisão tarifária periódica, avalie a oportunidade, a conveniência e a forma mais adequada de consideração dos efeitos do benefício fiscal decorrente da distribuição de juros sobre o capital próprio, na forma prevista na Lei $\mathrm{n}^{\circ}$ 9.249/1995;

9.3. diligenciar à Aneel, visando obter informações atualizadas sobre os estudos citados no item anterior, inclusive no que concerne à fixação de um prazo para a respectiva conclusão e remessa ao TCU;

9.4. dar ciência desta deliberação ao embargante;

9.5. encaminhar os autos à Secretaria de Recursos, para a realização do exame preliminar de admissibilidade do recurso apresentado pela Light Serviços de Eletricidade S.A.

\section{2) Acórdão 1.756/2004 - Plenário}

(ccclxxii) Data da sessão: 10/11/2004.

(ccclxxiii) Revisor: Benjamin Zymler.

(ccclxxiv) Área: competência do TCU.

(ccclxxv) Tema: agência reguladora.

(ccclxxvi) Subtema: abrangência.

438 “Art. $7^{\circ}$ A administração da Aneel será objeto de contrato de gestão, negociado e celebrado entre a Diretoria e o Poder Executivo no prazo máximo de noventa dias após a nomeação do Diretor-Geral, devendo uma cópia do instrumento ser encaminhada para registro no Tribunal de Contas da União, onde servirá de peça de referência em auditoria operacional." 
(ccclxxvii) Outros indexadores: fiscalização.

(ccclxxviii) Tipo do processo: desestatização.

(ccclxxix) Enunciado: "o TCU deve atuar de forma complementar à ação das entidades reguladoras no que concerne ao acompanhamento da outorga e da execução contratual dos serviços concedidos."

(ccclxxx) Objeto:

Embargos de Declaração opostos por José Mário de Miranda Abdo, DiretorPresidente da Agência Nacional de Energia Elétrica - Aneel, contra o item 9.1 e subitens do Acórdão 555/2004 - TCU - Plenário, cujos termos in verbis transcrevo:

"9.1. determinar à Aneel que:

9.1.1 adote as providências necessárias para incluir, no cálculo do reposicionamento tarifário da ELETROPAULO, ocorrido em 2003, os efeitos do benefício fiscal previsto na Lei ${ }^{\circ} 9.249 / 95$, decorrentes da distribuição aos acionistas de juros sobre o capital próprio;

9.1.2 inclua, nos próximos processos de revisão tarifária, os efeitos do benefício fiscal previsto na Lei $\mathrm{n}^{\circ}$ 9.249/95, decorrentes da distribuição aos acionistas de juros sobre o capital próprio;".

Alega o embargante que o acórdão impugnado incorreu em omissão "ao não considerar que a ANEEL ainda desenvolve estudo com vistas a tomar decisão quanto ao benefício fiscal dentro do processo de revisão tarifária periódica, no contexto da regulação por incentivos".

(ccclxxxi) Agência: Aneel.

(ccclxxxii) Unidade técnica: Sefid.

(ccclxxxiii) Emissão de comando relacionado à função reguladora? Sim.

(ccclxxxiv) A análise da unidade técnica fiscalizadora foi acolhida pelo relator e pelo Plenário? O relator acolheu; o revisor e o Plenário, não. Divergência de entendimento, entre o relator do acórdão embargado (Walton Alencar Rodrigues), o revisor (Benjamin Zymler) e o Ministério Público junto ao TCU, sobre a abrangência da competência do TCU. Voto paradigmático. Usar resumo.

(ccclxxxv) Fundamento normativo: Instrução Normativa $n^{\circ} 43 / 2002$; art. $6^{\circ}$ da Lei $n^{\circ}$ 8.987/1995; art. $7^{0439}$ da Lei no 9.427/1996; art. 71, IV, da Constituição Federal.

(ccclxxxvi) Precedentes citados: não há precedentes citados.

(ccclxxxvii) Enquadramento: função adjudicatória/normativa (referente à Resolução Aneel no 323/2003).

439 “Art. $7^{\circ}$ A administração da Aneel será objeto de contrato de gestão, negociado e celebrado entre a Diretoria e o Poder Executivo no prazo máximo de noventa dias após a nomeação do Diretor-Geral, devendo uma cópia do instrumento ser encaminhada para registro no Tribunal de Contas da União, onde servirá de peça de referência em auditoria operacional.” 
(ccclxxxviii) Resultado do controle: recomendação (mudança da natureza da decisão, de determinação para recomendação).

(ccclxxxix) Entendimento do acórdão: com fundamento nos arts. 32, II, e 34 da Lei $\mathrm{n}^{\mathrm{o}}$ 8.443/1992, c/c o art. 15, II, do Regimento Interno do Tribunal, em:

9.1. conhecer dos presentes embargos de declaração, para, no mérito, dar-lhes provimento;

9.2. recomendar à Aneel que, no estudo específico que aquela agência vem conduzindo no contexto do processo de revisão tarifária periódica, avalie a oportunidade, a conveniência e a forma mais adequada de consideração dos efeitos do benefício fiscal decorrente da distribuição de juros sobre o capital próprio, na forma prevista na Lei $\mathrm{n}^{\circ}$ 9.249/1995;

9.3. diligenciar à Aneel, visando obter informações atualizadas sobre os estudos citados no item anterior, inclusive no que concerne à fixação de um prazo para a respectiva conclusão e remessa ao TCU;

9.4. dar ciência desta deliberação ao embargante;

9.5. encaminhar os autos à Secretaria de Recursos para a realização do exame preliminar de admissibilidade do recurso apresentado pela Eletropaulo Metropolitana Eletricidade de São Paulo S.A. (grifo nosso).

\section{3) Acórdão 1.703/2004 - Plenário}

(cccxc)Data da sessão: 03/11/2004.

(cccxci) Relator: Benjamin Zymler.

(cccxcii) Área: competência do TCU.

(cccxciii) Tema: agência reguladora.

(cccxciv) Subtema: abrangência.

(cccxcv) Outros indexadores: ilegalidade, ato discricionário, fiscalização.

(cccxcvi) Tipo do processo: relatório de auditoria.

(ccexcvii) Enunciado:

A fiscalização do TCU, em processo de regulação, deve ser sempre de segunda ordem, sendo seu objeto a atuação das agências reguladoras como agentes estabilizadores e mediadores do jogo regulatório, não devendo versar sobre esse jogo regulatório em si mesmo considerado.

$[\ldots]$

No caso de atos irregulares vinculados, ou seja, quando entidades reguladoras violem expressa disposição legal, o TCU pode determinar a adoção das providências necessárias à correção das irregularidades detectadas. Se o ato for discricionário, praticado de forma motivada e visando satisfazer o interesse público, o Tribunal pode unicamente recomendar a adoção de providências que considerar mais adequadas. Contudo, caso o ato discricionário contenha vício de ilegalidade, o TCU é competente para avaliá-lo e para determinar a adoção das providências necessárias ao respectivo saneamento, podendo, inclusive, determinar sua anulação. 
(cccxcviii) Objeto: pedido de reexame interposto pela Concessionária Rio-Teresópolis S. A. (CRT), em face do Acórdão 988/2004-Plenário, o qual se refere à auditoria que foi realizada no extinto Departamento Nacional de Estradas de Rodagem (DNER), com o objetivo de verificar a adequação dos valores do pedágio cobrado na rodovia RioTeresópolis, acompanhar a execução do contrato de concessão e avaliar o equilíbrio econômico-financeiro do contrato. A recorrente (CRT) manifestou sua irresignação com relação a determinações dirigidas pelo tribunal à ANTT, em conformidade com as quais essa agência deverá adotar providências a fim de estabelecer a Taxa Interna de Retorno (TIR) obtida do fluxo de caixa não alavancado como indicador do equilíbrio econômico-financeiro do contrato PG no 156/1995-00, celebrado pelo DNER e pela CRT, com o fito de obter o reequilíbrio econômico-financeiro desse contrato.

(cccxcix) Agência: ANTT.

(cd) Unidade técnica: Serur.

(cdi) Emissão de comando relacionado à atividade-fim da agência? Sim.

(cdii) A análise da unidade técnica fiscalizadora foi acolhida pelo relator e pelo Plenário?

Parcialmente. Houve voto dissidente, de Adylson Motta:

A questão em apreciação diz respeito ao TCU dever ou não fazer determinações diante da constatação de ilegalidade e descumprimento de cláusulas contratuais conforme ocorre nestes autos ao fiscalizar a atuação do agente público responsável pela fiscalização dos contratos de concessão de serviço público. No caso em apreciação, o DNER, então na função de poder concedente, ao recomendar à CRT o encaminhamento do fluxo de caixa não-alavancado a partir da $4^{\text {a }}$ adequação, ao invés do fluxo de caixa da proposta da licitante vencedora do certame, incorreu em descumprimento da Lei $\mathbf{n}^{\mathbf{0}} \mathbf{8 . 9 8 7 / 9 5}$ e de diversas cláusulas do edital e do contrato, conforme pode-se observar da análise empreendida pela Secretaria de Recursos. A Serur, ao tratar da questão ora trazida à baila, assim se manifestou: "exsurge questão relativa à competência do TCU para efetuar determinações às Agências Reguladoras. Ressalte-se que o Tribunal não está se imiscuindo nas atividades finalísticas da ANTT, mas velando pelo cumprimento da lei e do próprio contrato firmado. Logo, sua atuação neste caso está em plena conformidade com a missão constitucional desta Corte de Contas. Ao exercer, como manda a Constituição Federal, o controle externo sobre as atividades desenvolvidas pelas agências reguladoras, que são autarquias especiais integrantes do Poder Executivo, o TCU não as substitui nem limita seus poderes. Apenas verifica e garante, visando à segurança de toda a sociedade, que as agências estão atuando em conformidade com as leis do país e respeitando os contratos assinados". Entendo que o TCU não pode abrir mão de uma faculdade constitucional e legal, deixando a mercê do agente público a possibilidade de sanar ou não ilegalidades e impropriedades claramente identificadas por esta Corte na regulação dos serviços públicos, cuja titularidade é da União. Dessa forma, pedindo vênia ao Nobre Relator, apresento esta Declaração de Voto com o intuito de que esta Corte de Contas faça determinações e não apenas recomendações ao órgão fiscalizado para o caso 
vertente e Voto, acolhendo a proposta da Serur, no sentido de que seja negado provimento ao Recurso ora analisado. (grifos nossos).

(cdiii) Fundamento normativo: arts. 175, parágrafo único, IV, da Constituição Federal; $6^{\circ}$, $\S 1^{\circ}$, da Lei ${ }^{\mathrm{o}} 8.987 / 1995 ; 43$, I, da Lei $\mathrm{n}^{\mathrm{o}} 8.443 / 1992$; e 250, II, do Regimento Interno do TCU.

(cdiv) Precedentes citados:-

(cdv) Enquadramento: função adjudicatória.

(cdvi) Resultado do controle: recomendações e determinações.

(cdvii) Entendimento do acórdão: o acórdão seguiu entendimento apresentado pelo relator.

33.Com espeque nesses argumentos, entendo que compete a este Tribunal recomendar a adoção das providências que se fizerem necessárias para tornar mais eficiente a atuação finalística e discricionária das agências reguladoras. De maneira semelhante a que se verifica nas auditorias operacionais, agora tão freqüentes nesta Corte, o produto final das auditorias realizadas nessas atividades deve ser um conjunto de propostas e recomendações, cuja implementação propiciará uma maior qualidade na prestação de serviços públicos. Porém, quando for detectado o descumprimento de uma norma jurídica, o TCU pode e deve determinar a adoção das medidas tendentes a ilidir essa irregularidade. 34.Assim sendo, julgo que deve ser dado provimento parcial ao recurso interposto pela CRT, sendo o Acórdão ora recorrido reformado no sentido de transformar em recomendações todas as determinações relativas à consideração ou não da alavancagem financeira no levantamento do fluxo de caixa e no cálculo da taxa de retorno da concessão da Rodovia Rio-Teresópolis, tendo em vista que essas questões não estavam disciplinadas em lei nem foram definidas de forma clara no edital de licitação e no contrato de concessão firmado. Consequentemente, as divergências existentes sobre esses pontos devem ser resolvidas pela ANTT, que se valerá para tanto de sua competência discricionária. (Voto do relator, grifos nossos).

Acórdão:

ACORDAM os Ministros do Tribunal de Contas da União, reunidos em Sessão do Plenário, ante as razões expostas pelo Relator, em:

9.1. conhecer do presente Pedido de Reexame, com fundamento nos artigos 32, parágrafo único, 33 e 48 da Lei $n^{\circ} 8.443 / 1992$, para, no mérito, conceder-lhe provimento parcial;

9.2. alterar a redação do Acórdão 988/2004 - Plenário, para transformar em recomendações todas as determinações relativas à consideração ou não da alavancagem financeira no levantamento do fluxo de caixa e no cálculo da taxa de retorno da concessão da Rodovia Rio-Teresópolis.

[...] nos artigos 43, inciso I, da Lei $n^{\circ} 8.443 / 1992$ e 250, inciso II, do Regimento Interno do TCU, recomendar à Agência Nacional de Transportes Terrestres (ANTT) que avalie a conveniência e a oportunidade de estabelecer a Taxa Interna de Retorno - TIR obtida do fluxo de caixa não-alavancado como indicador do equilíbrio econômico-financeiro do contrato PG-156/95-00, firmado pelo extinto DNER e pela Concessionária Rio-Teresópolis;

9.4 - com fundamento no art. 43, inciso I, da Lei $n^{\circ}$ 8.443/1992 c/c o art. 250, inciso II, do Regimento Interno recomendar à Agência Nacional de Transportes Terrestres (ANTT) que analise a conveniência e a oportunidade de reavaliar os 
índices de correção utilizados nas revisões 1, 2, 3, 4, 5, 6, 7 e 8, considerando a Taxa Interna de Retorno - TIR resultante do fluxo de caixa não-alavancado da proposta $(17,28 \%) ;[\ldots]$. (grifos nossos). 